\title{
Intensive Pedestrian Survey along the Banks of the San Antonio River: Museum "Urban" Reach Section of the San Antonio River Improvements Project, Bexar County, Texas
}

Antonia L. Figueroa

Center for Archeological Research, University of Texas at San Antonio

Kristi M. Ulrich

Christopher Caran

Charles A. Speer

Follow this and additional works at: https://scholarworks.sfasu.edu/ita

Part of the American Material Culture Commons, Archaeological Anthropology Commons, Environmental Studies Commons, Other American Studies Commons, Other Arts and Humanities Commons, Other History of Art, Architecture, and Archaeology Commons, and the United States History Commons

Tell us how this article helped you.

This Article is brought to you for free and open access by the Center for Regional Heritage Research at SFA ScholarWorks. It has been accepted for inclusion in Index of Texas Archaeology: Open Access Gray Literature from the Lone Star State by an authorized editor of SFA ScholarWorks. For more information, please contact cdsscholarworks@sfasu.edu. 
Intensive Pedestrian Survey along the Banks of the San Antonio River: Museum "Urban" Reach Section of the San Antonio River Improvements Project, Bexar County, Texas

Creative Commons License

(c) (1) \&

This work is licensed under a Creative Commons Attribution-NonCommercial 4.0 International License 


\title{
Intensive Pedestrian Survey along the Banks of the San Antonio River: Museum "Urban" Reach Section of the San Antonio River Improvements Project, Bexar County, Texas
}

\author{
by \\ Antonia L. Figueroa, Kristi M. Ulrich, S. Christopher Caran, \\ and Charles A. Speer \\ with contributions by \\ Vaughn M. Bryant and Steve A. Tomka
}

Texas Antiquities Permit No. 3852

Principal Investigator

Steve A. Tomka

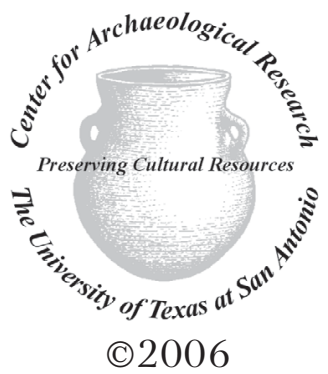

Prepared for

Raba-Kistner Consultants, Inc.

12821 W. Golden Lane

San Antonio TX 78249
Prepared by

Center for Archaeological Research The University of Texas at San Antonio Archaeological Report, No. 371 
A list of publications offered by the Center for Archaeological Research is available. Call (210) 458-4378; write to the Center for Archaeological Research, The University of Texas at San Antonio, One UTSA Circle, San Antonio, Texas 78249-1644; e-mail to car@utsa.edu; or visit CAR's web site at http://car.utsa.edu. 


\begin{abstract}
In the spring and fall of 2005, the Center for Archaeological Research at the University of Texas at San Antonio carried out reconnaissance and intensive pedestrian survey of the Museum "Urban" Reach portion of the San Antonio River Improvements Project in San Antonio, Bexar County, Texas. The excavation of eight backhoe trenches and the stratigraphy of 17 auger boreholes revealed the San Antonio River and adjacent properties have been modified extensively since Spanish Colonial settlement. Due to the extensive modifications, the likelihood of encountering prehistoric and early historic sites along the Museum Reach portion of the San Antonio River is minimal. Pollen analysis of samples taken from the project area did not provide any significant information on the paleoenvironment. The compilation of a standing structure survey and a deed and property research revealed that there are structures along the project area that are significant to local history. Sediment subsamples from selected boreholes examined by the project geomorphologist and all project-related documents and records are permanently curated at the Center for Archaeological Research.
\end{abstract}




\section{Table of Contents}

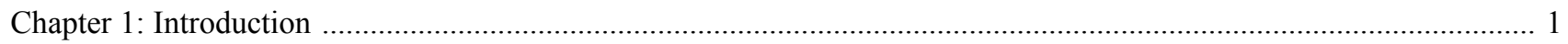

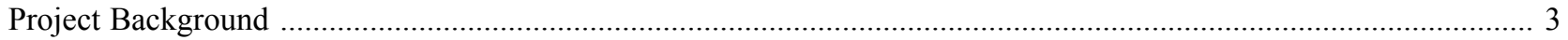

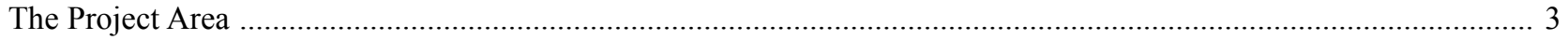

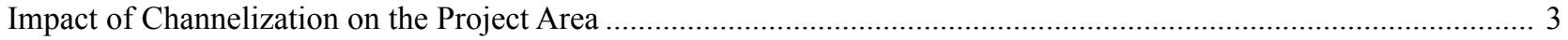

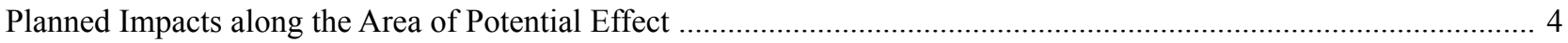

Chapter 2: Historic Resources in the Project Area ............................................................................................. 5

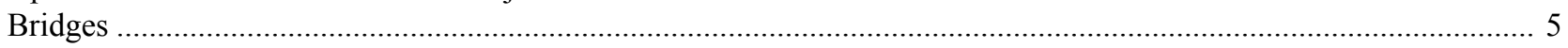

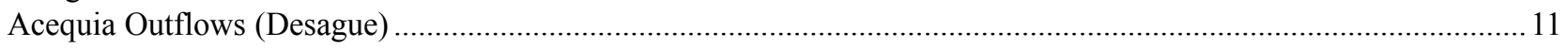

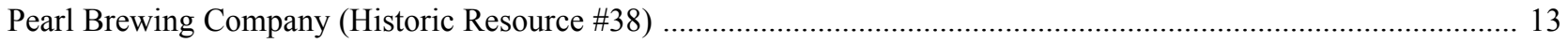

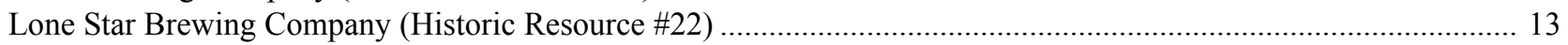

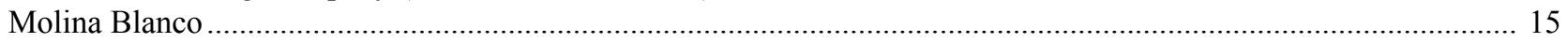

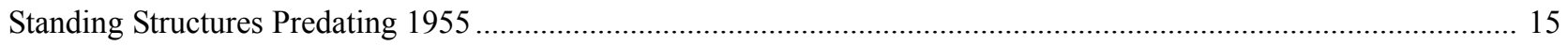

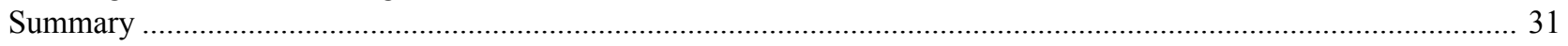

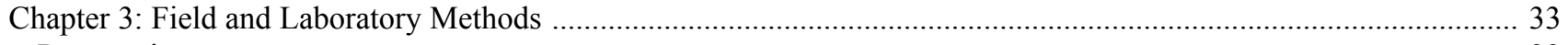

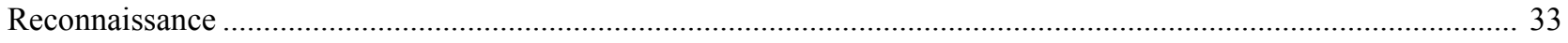

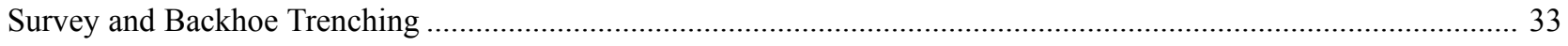

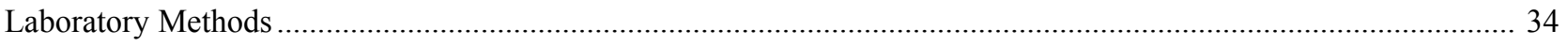

Chapter 4: Results of Reconnaissance Survey and Backhoe Trenching ................................................................... 35

Results of the Reconnaissance Survey of the Project Area ……........................................................................... 35

Geoarchaeology of the Proposed San Antonio River Improvements Project, Museum Reach by S. Christopher Caran

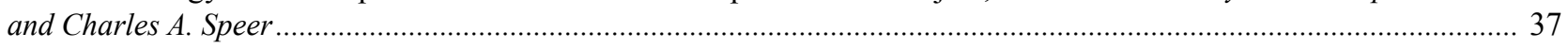

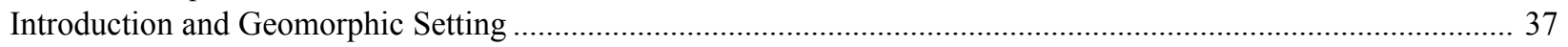

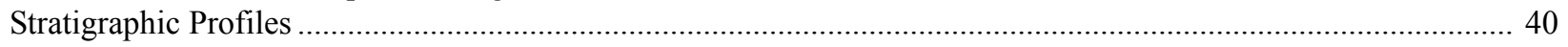

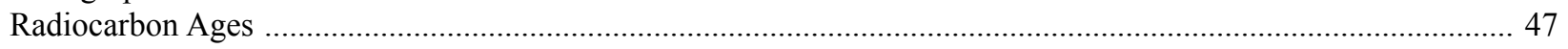

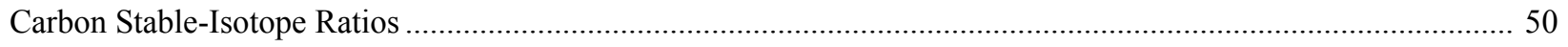

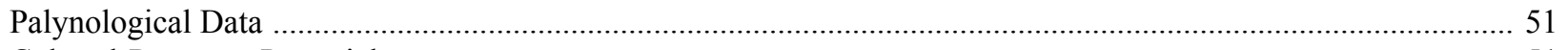

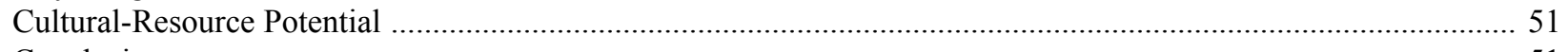

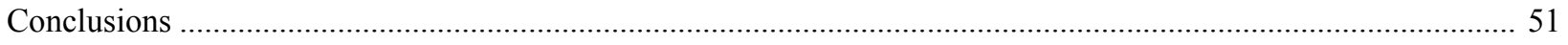

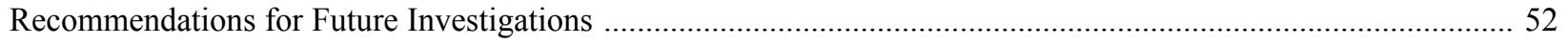

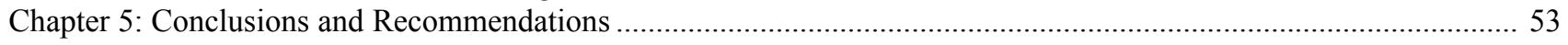

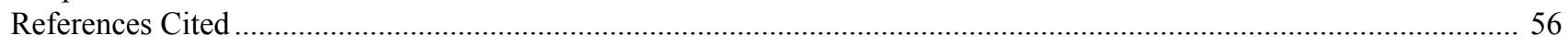

Appendix A: Stratigraphic Profiles of Backhoe Trenches by S. Christopher Caran and Charles A. Speer ......................... 64

Appendix B: Stratigraphic Profiles of Boreholes by S. Christopher Caran and Charles A. Speer ................................... 70

Appendix C: Pollen Extraction and Summary of 15 Sediment Samples from San Antonio River Improvement Project

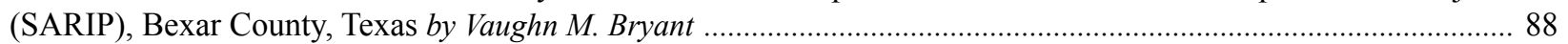




\section{List of Figures}

Figure 1-1. The location of the Museum "Urban" Reach Project along the San Antonio River, Bexar County, Texas. ..... 1

Figure 1-2. Museum "Urban" Reach project area. …........................................................................................... 2

Figure 2-1. Museum "Urban" Reach project area, showing locations of historic resources by inventory number,

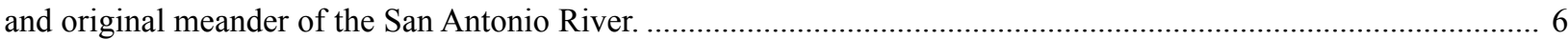

Figure 2-2. The Fourth Street Bridge located on Lexington Avenue (Historic Resource \#1). ....................................... 8

Figure 2-3. The Avenue "B" Bridge located on Jones Avenue (Historic Resource \#15). ................................................ 9

Figure 2-4. The Grayson Street Bridge located on Grayson Street (Historic Resource \#43). ........................................ 9

Figure 2-5. The Josephine Street Bridge located on Josephine Street (Historic Resource \#47) .................................... 10

Figure 2-6. The iron bridge from Lone Star Brewery located on Roy Smith (Historic Resource \#48)............................ 11

Figure 2-7. Sanborn map, dated 1904, depicting the location of the Ochs and Aschbacher Weiss Brewery. ................... 12

Figure 2-8. Wooden trestle bridge located between Camden Street and IH-35. ........................................................ 13

Figure 2-9. Pearl Brewing Company (Historic Resource \#38, east façade). .................................................................. 14

Figure 2-10. Lone Star Brewing Company (Historic Resource \#22, southwest façade). ............................................... 14

Figure 2-11. Sanborn map, dated 1922, depicting the location of the Lone Star Cotton Mills, Inc. ................................ 16

Figure 2-12. Historic Resource \#10 located on Avenue B (southwest façade). ............................................................ 17

Figure 2-13. Sanborn map, dated 1911, depicting the location of the bookbinding facility.......................................... 18

Figure 2-14. Sanborn map, dated 1896, depicting the location of the Crystal Ice and Manufacturing Company............. 19

Figure 2-15. Sanborn map, dated 1904, depicting the location of the Artesian Ice Company. ....................................... 20

Figure 2-16. Historic Resource \#11 located on Ninth Street (north façade) ................................................................... 21

Figure 2-17. VFW Post 76 and former residence of the Lone Star Brewery brew master (Historic Resource \#13)......... 22

Figure 2-18. Historic Resource \#16 located on Avenue B (southeast façade). ............................................................. 23

Figure 2-19. Historic Resource \#18 located on Avenue B (southeast façade). ................................................................ 24

Figure 2-20. Historic Resource \#19 located on Avenue B (southeast façade). .............................................................. 25

Figure 2-21. Historic Resource \#20 located on Avenue B (southeast façade). ............................................................... 25

Figure 2-22. Historic Resource \#21 located on Avenue B (southeast façade). ............................................................. 26

Figure 2-23. Historic Resource \#26 located on Avenue A (southeast façade). ............................................................... 26

Figure 2-24. Historic Resource \#32 located on East Quincy Street (north façade). ........................................................ 27

Figure 2-25. Historic Resource \#33 located on Newell Avenue (southwest façade). ..................................................... 28

Figure 2-26. Historic Resource \#35 located on Newell Avenue (west façade) ............................................................... 29

Figure 2-27. Historic Resource \#37 located on Elmira Street (view from the southeast). ............................................. 29

Figure 2-28. Historic Resource \#42 located on Grayson Street (west façade). ............................................................ 30

Figure 2-29. Historic Resource \#46 (Taco Land), east façade, located on Grayson Street. ........................................... 31

Figure 4-1. Concrete embankments near the northern end of project area, looking south from

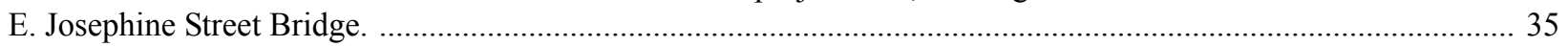

Figure 4-2. West bank of San Antonio River under the Newell Street Bridge. ............................................................... 35

Figure 4-3. Cleared portion of west bank of the San Antonio River near the IH-35 overpass. ...................................... 36

Figure 4-4. Lower terrace immediately adjacent to active channel of the San Antonio River. ...................................... 36

Figure 4-5. Northern segment of the upper terrace available for backhoe trenching along project area

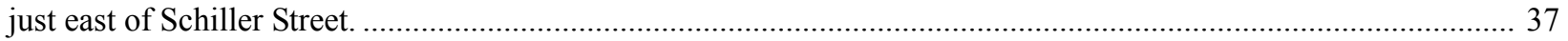

Figure 4-6. Segment of upper terrace available for backhoe trenching just south of W. Jones Avenue Bridge. .............. 37

Figure 4-7. Southern segment of upper terrace on west bank of river, just north of Ninth Street Bridge. ....................... 37

Figure 4-8. Locations of backhoe trenches and auger bores in the project area. ........................................................... 41

Figure 4-9. Stratigraphic profile exposed in northern wall of Backhoe Trench 8. ..................................................... 42

Figure 4-10. Down-valley stratigraphic cross-section showing representative sample profiles..................................... 43

Figure 4-11. Road alignments reflecting Spanish water-distribution network. ............................................................. 45

Figure 4-12. Age:depth relationships, Boreholes 2, 23, and 63, and Backhoe Trench 8............................................ 48

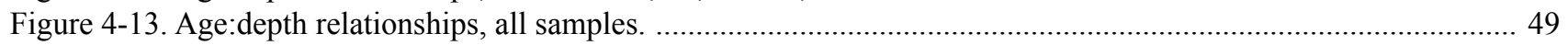

Figure C-1. Selected pollen types from site samples. ........................................................................................... 91 


\section{List of Tables}

Table 2-1. Inventory of Historic Resources along the San Antonio River ...................................................................... 7

Table A-1. Summary of Stratigraphic Profiles Exposed in Backhoe Trenches 1 through 8 (BHT1-8) ........................... 64

Table A-2. Stratigraphic Profile Exposed in the Northern Wall of Backhoe Trench 8 (BHT8), Ninth Street Locality ..... 67

Table B-1. Description of Selected Borehole Profiles, Proposed San Antonio River Improvement Project,

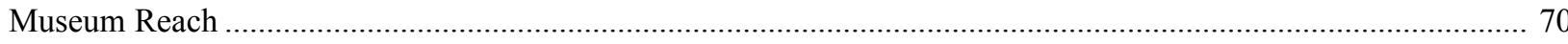

Table B-2. Radiocarbon and Carbon Stable-Isotope Analyses of Humate Samples ....................................................... 86

Table C-1. SARIP Soil Samples Collected for Pollen Studies ..................................................................................... 88 


\section{Acknowledgments}

This project was accomplished with the aid of several individuals and agencies. The authors would like to thank to the City of San Antonio, the San Antonio River Oversight Committee, and the San Antonio River Authority. Thanks to the following CAR staff that worked on the project area at various times: Jon Dowling, Bryant Saner, and Charles Speer. Christopher Caran served as project geomorphologist. The staff of Arias and Associates, Inc., particularly Laboratory Supervisor Alex Salcedo and Geotechnical Operations Manager Christopher M. Szymczak, P.E., provided copies of borehole drilling records and cordially allowed access to their laboratory for description and subsampling of borehole cores. Their assistance and collaboration are greatly appreciated. Steve Tomka served as Principal Investigator and reviewed the draft and final report. Finally, thanks to Bruce Moses, Leonard Kemp and Rick Young for drafting the figures, and Claudia Branton and Jennifer Thompson for editing the final manuscript. 



\section{Chapter 1: Introduction}

During the spring and fall of 2005, the Center for Archaeological Research (CAR) at The University of Texas at San Antonio conducted reconnaissance and intensive pedestrian survey of the Museum "Urban" Reach portion of the San Antonio River Improvements Project in San Antonio, Bexar County, Texas (Figure 1-1). The San Antonio River Improvements Project is a joint effort between the City of San Antonio, the San Antonio River Oversight Committee, Bexar County, and the San Antonio River Authority to develop and restore a 13-mile stretch of the San Antonio
River. The San Antonio River Improvements Project is comprised of two areas, the southern "Historical" Mission Reach and northern Museum Reach that consists of the "Urban" and "Park" sections. This report focuses on the "Urban" section that is between Josephine Street and Lexington Avenue, and the results of the reconnaissance, backhoe trenching and auger boring conducted within the project area (Figure 1-2). These investigations were conducted under Texas Antiquities Permit No. 3852 with Steve Tomka serving as Principal Investigator.

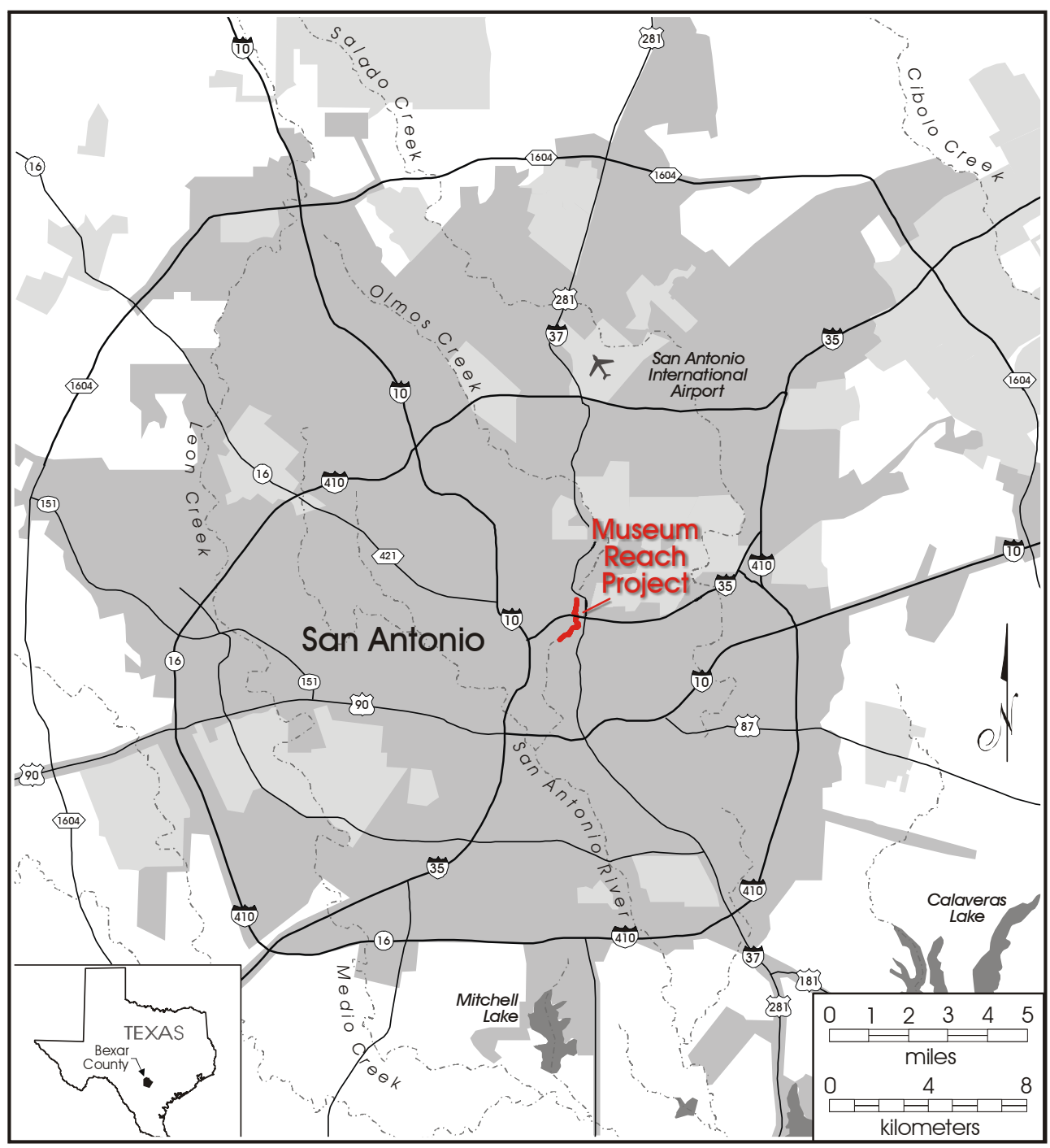

Figure 1-1. The location of the Museum "Urban” Reach Project along the San Antonio River, Bexar County, Texas. 


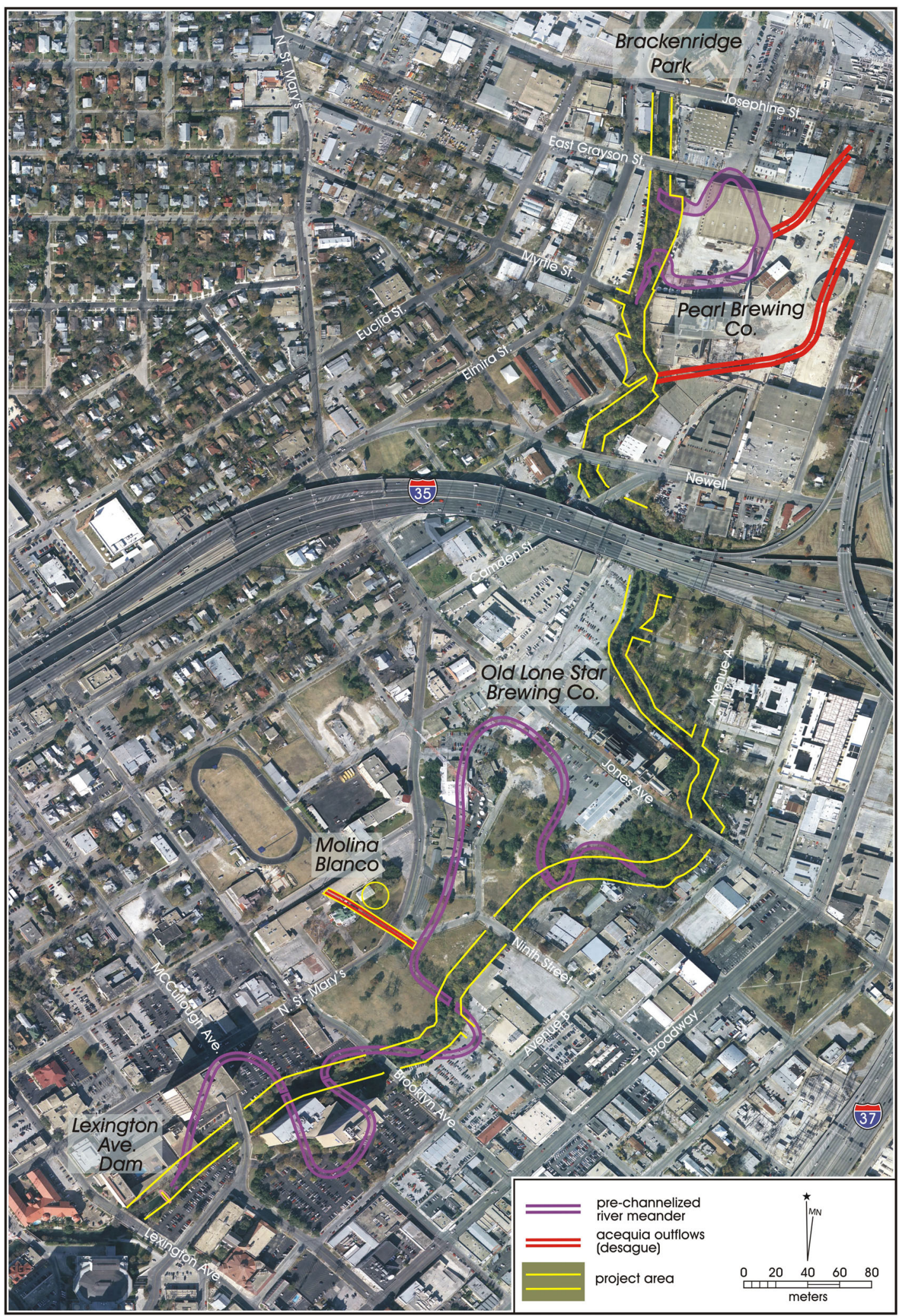

Figure 1-2. Museum "Urban" Reach project area. 
The remainder of this chapter discusses the background of the Museum Reach project area and the historical channelization of the San Antonio River. It also discusses the planned impacts that will occur along the Area of Potential Effect (APE). The archaeological background of the project area is discussed, and the historic properties along the APE are specifically addressed, in Chapter 2. Chapter 3 reviews the field and laboratory methods employed during the project. Chapter 4 discusses the results of the reconnaissance, backhoe trenching and auger boring conducted in the project area. Chapter 5 provides conclusions and recommendations for the project area. Appendices A and B provide detailed backhoe trench and borehole profile descriptions, respectively. Pollen analysis of sediments taken from selected backhoe trenches was performed by Vaughn Bryant of Texas A\&M University and is presented in Appendix C.

\section{Project Background}

The Museum Reach project is a comprehensive program of flood control, restoration, recreation and amenity improvements guided by the principles of hydrology, nature and people. Concept design aims developed for this project reduce the threat of flooding, create a more natural design to the river that promotes fish and wildlife habitat, as well as enhance appreciation of the river's historic significance in the life and development of the community. The approach for the Museum Reach project is the application of fluvial geomorphology that restores the river to a more natural condition and creates a more stable river.

In 2002, Ford, Powell and Carson Architects \& Planners, Inc. of San Antonio hired the Center for Archaeological Research to compile a comprehensive record of all known, previously recorded cultural resources along the Museum Reach section of the San Antonio River Improvements Project area. As part of this research, CAR produced a document which listed all known cultural resources present along the proposed project right-of-way (ROW; Cox et al. 2002). Following the production of the document, funding could not be secured for the river improvements proposed within the Museum "Park" Reach portion. Funding was obtained for the Museum "Urban" Reach portion of the project extending from Lexington Avenue at the southern terminus to Josephine Street at its northern terminus.

\section{The Project Area}

The project area for the "Urban" section, and therefore the APE, represents the narrow corridor along the historically channelized San Antonio River between Josephine Street and Lexington Avenue in north-central San Antonio. The entirety of the "Urban" section that is the focus of this report is approximately 1.25 miles long.

The entire ROW of the project area consists of the active river channel and narrow strips of bank and floodplain along both sides of the channel. The active channel does not run down the center of the ROW, creating situations where the majority of the dry-land portion of the ROW occurs either on the east- or west-descending bank of the river rather than being evenly distributed on both banks. Due to the narrowness of the ROW and its uneven distribution along the APE, CAR decided to treat the entire 1.25-mile project area as a single, linear APE.

At its widest point, immediately south of Grayson Street, the project ROW is $150 \mathrm{ft}$. (approximately $46 \mathrm{~m}$ ) wide. At its narrowest point, in the vicinity of the Hops Building (the San Antonio Museum Art [SAMA]), the ROW measures approximately $75 \mathrm{ft}$. (approximately $24 \mathrm{~m}$ ) in maximum width. With the active channel taking up 20-30 $\mathrm{ft}$. along the APE, often the width of the combined dryland portion (i.e., east- and west-descending banks) of the ROW ranges from 45-120 ft.

\section{Impact of Channelization on the Project Area}

The channelization of the San Antonio River, which involved cutting through its original meanders to straighten the channel, occurred during the late 1930s (Cox et al. 2002). In two regions of the project area the pre-channelized river meander is at a substantial distance away from its current channel. One of these areas is found immediately south of East Grayson Street where the old river channel veers to the east near East Myrtle Street, forming a substantial meander that was eliminated by channelization. An even longer segment of a meander is present between West Jones Avenue and Lexington Avenue at the southern terminus of the project area. Within this segment, only a short section of the current channel has not been impacted by 
channelization. A number of the meanders within this section, historically referred to as the "Big Bend," veers some distance from the current channel both on the western and eastern banks of the river. Therefore, the current channelized portion of San Antonio River actually cuts across its former floodplain in these areas.

If the widths of surviving, unaltered segments of the San Antonio River channel are representative, channelization has destroyed all historic or prehistoric archaeological resources within the channel proper. Channelization activities may have also impacted any potential resources located on the immediate margins of the banks of the original river, although what the nature and degree of such impacts have been is difficult to discern. For instance, CAR staff recently revisited site 41BX254 located along the Mission Reach portion of the River Improvements Project. Despite the fact that the site is located only $60 \mathrm{ft} .(20 \mathrm{~m})$ from the edge of the channelized river, and is only covered by some three feet of soil, intact features are eroding out of the site along the pedestrian trail that runs past the site. It is likely that much of the site may have escaped impact during channelization despite its location so close to the primary impact area. Therefore, it is difficult to predict what level or degree of disturbance may be present along channelized versus "natural" portions of the river. Regardless, there is no particular reason why partially disturbed, or remnant portions of, prehistoric or historic archaeological sites would not occur along either section of the modern river. The only difference between the channelized and natural banks of the river would have been the original distance of sites from the pre-channelized stream.

\section{Planned Impacts along the Area of Potential Effect}

Based on the review of the site and section plans that encompass the project area from Josephine Street to Lexington Avenue, the width of the APE varies from approximately $73 \mathrm{ft}$. to $175 \mathrm{ft}$. and the depths of subsurface impacts range from as little as $12 \mathrm{ft}$. to as much as approximately $20 \mathrm{ft}$. below surface. The river topography cross-sections reviewed indicate that impacts along much of the ROW will reach a depth of $18 \mathrm{ft}$. (approximately $5.5 \mathrm{~m}$ ) below surface. The plans also indicate that in some sections of the project area (i.e., the vicinity of Jones Avenue, Avenue A and SAMA), as much as 3-5 ft. of fill will have to be added to bring the grade up to the desired height and profile.

A number of construction impacts will affect the ROW along the project area. Impacts include the construction of multiuse pathways, pedestrian pathways and bridges, planted areas, barge turning and passing basins, boat landing sites, access steps and ramps, docks, and a dam. The construction of retaining walls that will confine water flow to the deepest portion of the channel along the APE in general represent the deepest impacts along the project area. The construction of footings for other retaining walls and the building of multi-use pathways and pedestrian walkways represent the principal impacts along the channel. The need for boat loading ramps, landing areas, and turning basins will also impact the channel as will the construction of two pedestrian bridges and a dam just south of Eighth Street. 


\section{Chapter 2: Historic Resources in the Project Area}

The rich environment surrounding the San Antonio River basin attracted prehistoric inhabitants and the early Spanish entrada. The numerous prehistoric archaeological investigations conducted throughout Bexar County have revealed a long history of human occupation stretching back at least 10,000 years, beginning with the Paleoindian period and continuing into the Colonial period. Because river courses provided a rich and diverse range of edible and economically useful resources, these areas were the focal points of human activity and settlement. Often, the abundance of resources led to re-occupation of preferred localities on their banks, as evident in the large, deeply stratified archaeological sites rich in material culture found in these locations. In other instances, the exploitation of specific resources, such as mussel shell along particular stretches of river, resulted in special resource extraction localities characterized by an abundant yet narrower range of material culture (e.g., predominance of grinding implements) and cultural features (e.g., presence of hearth fields for food preparation). Several sites have been identified in the northern "Park" section of the Museum Reach in the environs of Brackenridge and are discussed in Cox et al. (2002).

The cultural resources identified in the Museum "Urban" Reach are confined to historic properties. Background research on historic properties discussed in this chapter is adopted from archival research conducted in 2002 (Cox et al. 2002) for the Museum Reach project. Information was also obtained from a standing structure survey of the historic resources along the San Antonio River from Josephine Street to Lexington Avenue prepared by Mainstreet Architects, Inc. (Mainstreet Architects 2005; Figure 2-1). Refer to Table 2-1 for a condensed list of these properties and buildings ("Historical Resources"). Documents such as Sanborn Maps (2006), public deed records available through the Bexar County Clerk's office (BCC), and the Bexar County Appraisal District (BCAD) archives were reviewed to obtain additional information on historic resources and to establish ownership of properties that were 50 years or more old. What follows is a discussion of historic properties that consist of bridges, buildings and one acequia outflow. The discussion will include the location of each property, ownership, estimated construction dates and structure descriptions.

\section{Bridges}

There are six bridges along the project corridor that are historically significant. These bridges were constructed as a result of river improvements authorized and funded under the administration of Mayor Chambers who served from 1927 to 1933. The Fourth Street Bridge, also known as the Lexington Avenue Bridge, is located in the 100 block of Lexington Avenue (Figure 2-2; Table 2-1:Historic Resource \#1). The bridge was constructed during river improvements between 1940 and 1941. It is a reinforced concrete bridge for vehicular traffic, with two load-bearing walls supporting the road deck. It has concrete sidewalks and concrete railings on both sides of the bridge's deck. The railings have five pillars each, of which two display plaques denoting the historical context of the bridge.

The Avenue " $\mathrm{B}$ " Bridge is located in the 100 block of Jones Avenue and was constructed in 1928 (Figure 2-3; Table 2-1:Historic Resource \#15). It is a reinforced concrete bridge for vehicular traffic. It is made up of two load-bearing reinforced concrete walls supporting the road deck. It has concrete sidewalks and concrete railings on both sides of the bridge's deck. The railings have seven rail pillars each and two display plaques denoting the historical context of the bridge.

The Grayson Street Bridge, or Grand Avenue Bridge, located in the 100 block of Grayson Street, was constructed in 1929 (Figure 2-4; Historic Resource \#43). It is a reinforced concrete bridge for vehicular traffic. It has concrete sidewalks and concrete railings on both sides of the bridge's deck. The concrete railings each have six concrete, square rail columns.

The Josephine Street Bridge, located in the 100 block of Josephine Street, was constructed in 1929 (Figure 2-5; Historic Resource \#47). The bridge is a reinforced concrete bridge for vehicular traffic. It has concrete sidewalks and concrete railings on both sides of the bridge's deck. It has concrete railings, each with six small, concrete, square rail columns. The Josephine Street Bridge was constructed as part of the river improvements occurring during the administration of Mayor Chambers. 


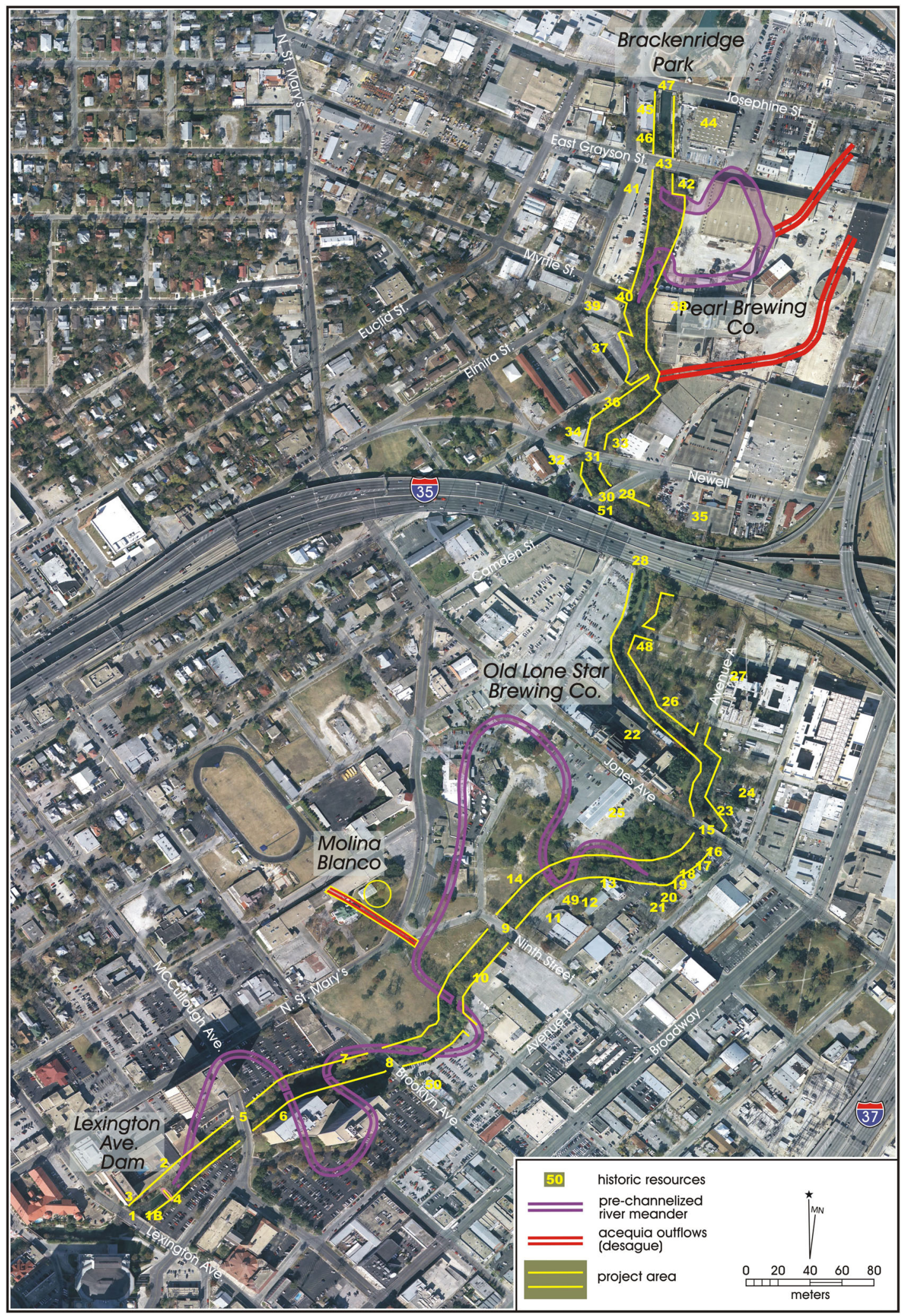

Figure 2-1. Museum "Urban" Reach project area, showing locations of historic resources by inventory number, and original meander of the San Antonio River. 
Table 2-1. Inventory of Historic Resources along the San Antonio River*

\begin{tabular}{|c|c|c|c|}
\hline $\begin{array}{c}\text { Historic } \\
\text { Resource } \\
\text { Inventory No. }\end{array}$ & Site Name/Function & Historic Name/Function & Type of Structure \\
\hline 1 & Lexington Avenue Bridge & Fourth Street Bridge & Bridge \\
\hline $1 \mathrm{~B}$ & Concrete storm drain & - & Water drain \\
\hline 2 & Clarion Fiesta Riverwalk Hotel & El Tropicana Riverwalk Hotel & Hotel \\
\hline 3 & Concrete slope to river & - & Water shed \\
\hline 4 & Concrete slope to river & - & Water shed \\
\hline 5 & McCullough Street Bridge & McCullough Street Bridge & Bridge \\
\hline 6 & SBC (now AT\&T) Building & - & Commercial building \\
\hline 7 & Concrete drainage pipe & - & Drain \\
\hline 8 & Brooklyn Avenue Bridge & Brooklyn Avenue Bridge & Bridge \\
\hline 9 & Ninth Avenue Bridge & Ninth Avenue Bridge & Bridge \\
\hline 10 & Covered parking & - & Parking structure \\
\hline 11 & Bowling Alley & Commercial building & Commercial block \\
\hline 12 & AMC Iron Works/Manhole & - & - \\
\hline 13 & VFW Post 76 & Residence & House \\
\hline 14 & Fallout Shelter & - & Fallout Shelter \\
\hline 15 & Avenue "B" Bridge & - & Bridge \\
\hline 16 & Lounge at Avenue "B" & Bar/Nightclub & Commercial building \\
\hline 17 & 1021 Avenue B & - & Commercial building compound \\
\hline 18 & Fisher Bros. Machine Shop & - & Commercial building \\
\hline 19 & Lion's Den - Reggae & Residence & Commercial building \\
\hline 20 & Residence at 1005 Avenue B & Restaurant & Residence \\
\hline 21 & Residence at 1001 Avenue B & Office & Commercial building \\
\hline 22 & San Antonio Museum of Art & Lone Star Brewery & Commercial building \\
\hline 23 & Hughes Plumbing & - & Storage facility \\
\hline 24 & Alamo Wrecker Service & - & Commercial site \\
\hline 25 & Exhibits Building & - & Storage facility \\
\hline 26 & Warehouse/Storage & Book binding facility & Industrial facility \\
\hline 27 & High Rise Apartments & - & Commercial multifamily residence \\
\hline 28 & IH-35 Overpass & - & Highway \\
\hline 29 & Concrete drainage pipe & - & Water drain \\
\hline 30 & Camden Bridge & Camden Bridge & Bridge \\
\hline 31 & Newell Bridge & Newell Bridge & Bridge \\
\hline 32 & Mission Paint and Body & Southern Express Co. & Industrial facility \\
\hline 33 & Samuel Glass Company & Samuel Glass Company & Industrial facility \\
\hline 34 & Hudson Corp. of Texas & - & Industrial facility \\
\hline 35 & Advanced First Auto Collision & Yellow Cab \& Baggage Co. & Commercial site \\
\hline 36 & Hudson Corp. of Texas & Storage tanks & Storage tanks \\
\hline 37 & Elmira Motor Inn & - & Motel/commercial \\
\hline 38 & Pearl Light Brewery & Pearl Light Brewery & Commercial building \\
\hline 39 & S.W. C. Club & Restaurant & Commercial building \\
\hline 40 & Concrete drainage pipe & - & Drain \\
\hline 41 & Oak Farms Storage Facility & - & Storage facility \\
\hline 42 & Craft Services & - & Commercial building \\
\hline 43 & Grayson Street Bridge & Grand Avenue Bridge & Bridge \\
\hline 44 & Consolidated Electric Distribution & - & Warehouse \\
\hline
\end{tabular}


Table 2-1. Continued...

\begin{tabular}{|c|c|c|c|}
\hline $\begin{array}{c}\text { Historic } \\
\text { Resource } \\
\text { Inventory No. }\end{array}$ & Site Name/Function & Historic Name/Function & Type of Structure \\
\hline 45 & Plastic Supply & Warehouse & Commercial building \\
\hline 46 & Taco Land & - & Commercial building \\
\hline 47 & Josephine Street Bridge & Josephine Street Bridge & Bridge \\
\hline 48 & Iron Bridge from Lone Star Brewery & Pedestrian Bridge & Bridge \\
\hline 49 & Residence at 120 Ninth Street B & Residence & Commercial building \\
\hline 50 & $\mathrm{H}_{2} 0$ (restaurant) & - & Water drain \\
\hline 51 & Concrete storm drain & - & \\
\hline
\end{tabular}

*Information from Historic Resources Inventory Forms prepared by Mainstreet Architects, Inc.

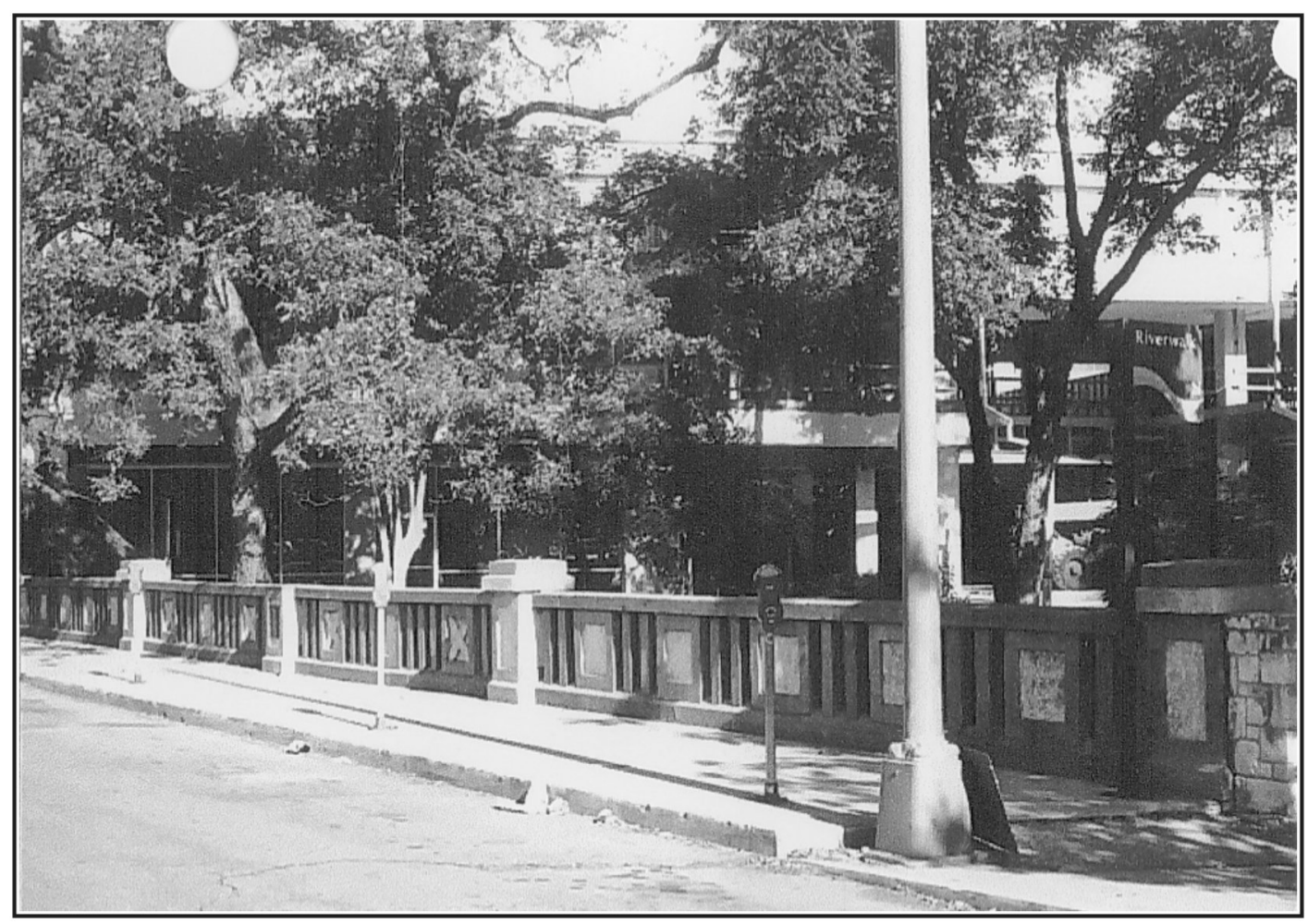

Figure 2-2. The Fourth Street Bridge located on Lexington Avenue (Historic Resource \#1). 


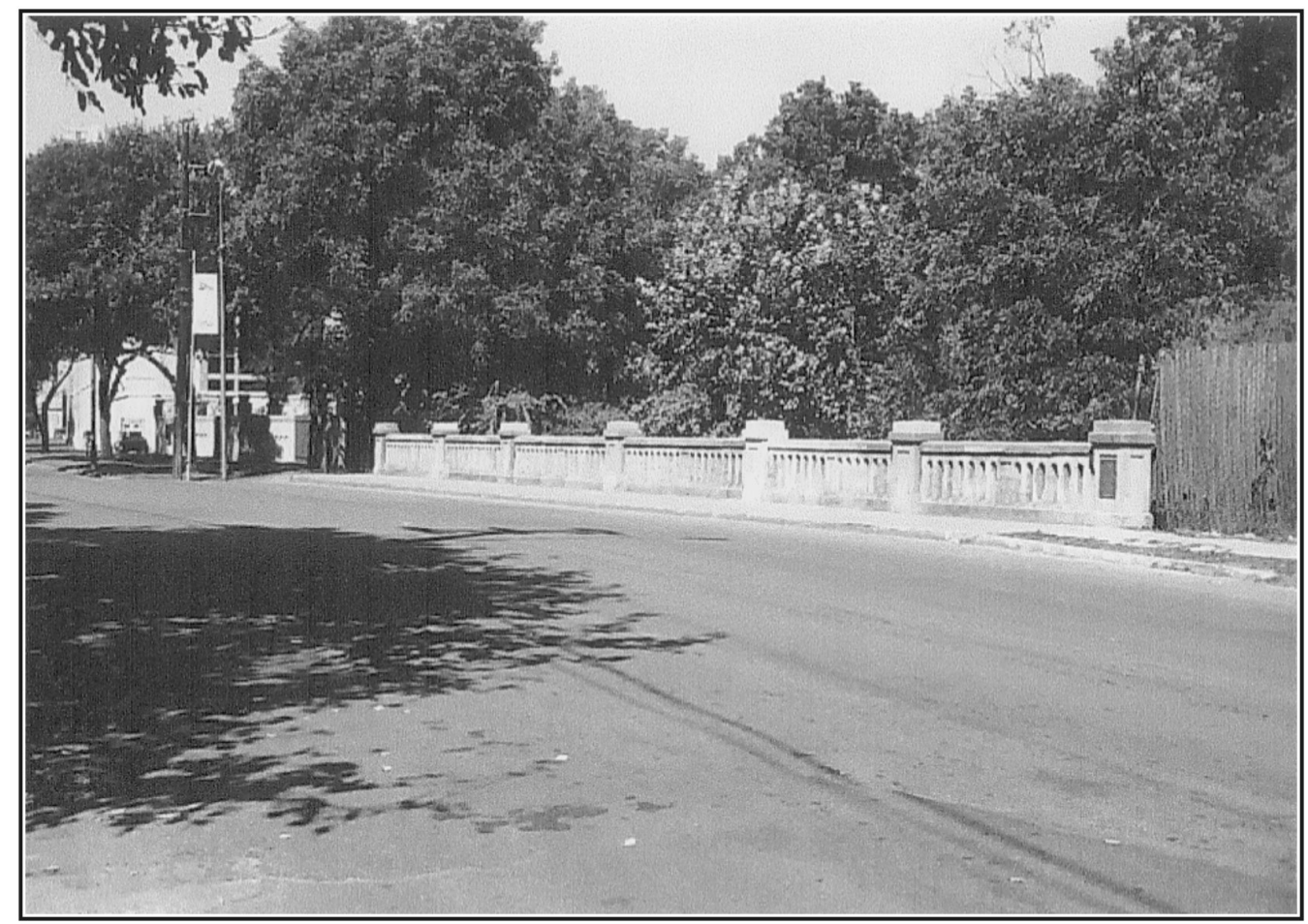

Figure 2-3. The Avenue "B" Bridge located on Jones Avenue (Historic Resource \#15).

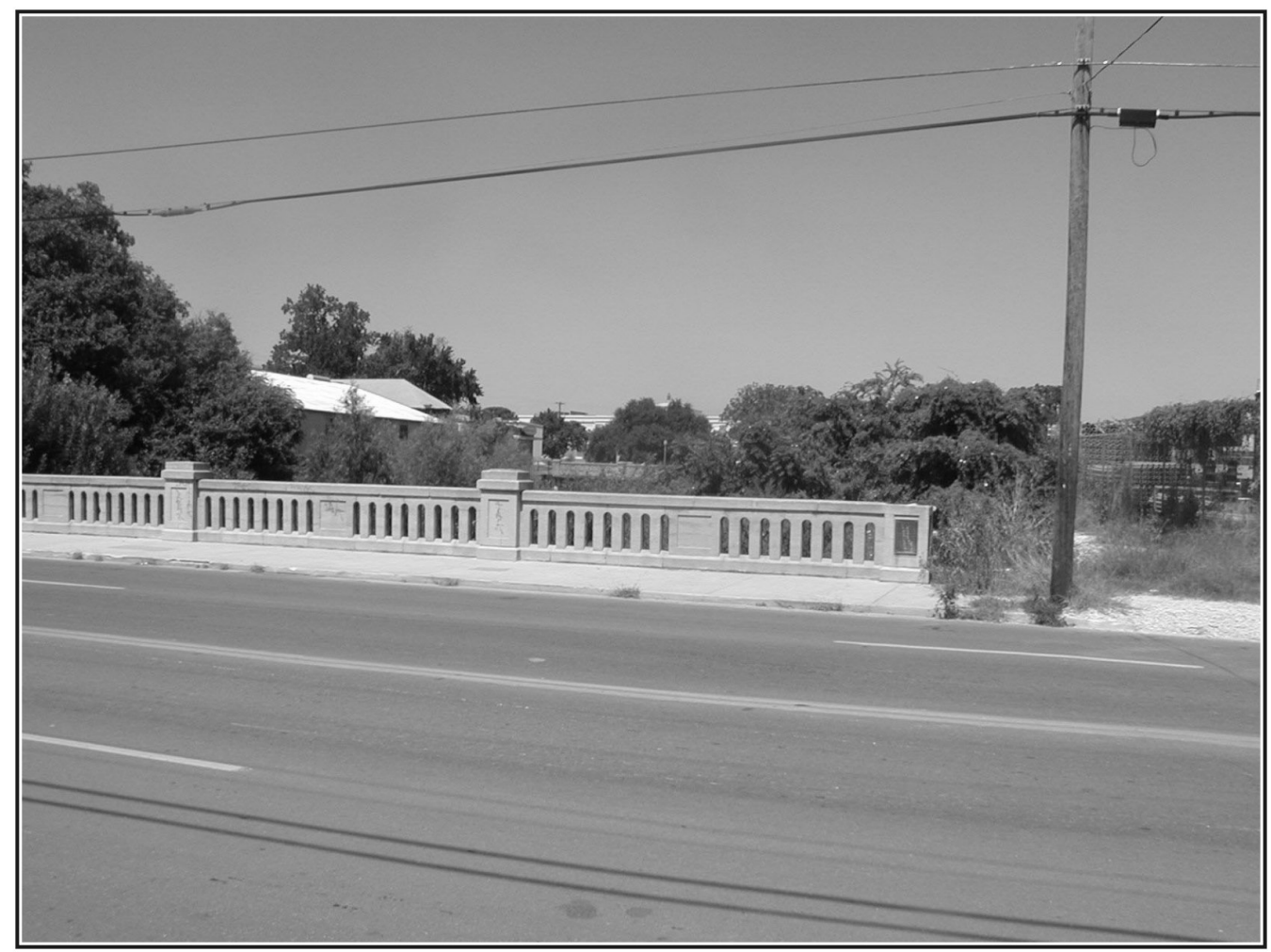

Figure 2-4. The Grayson Street Bridge located on Grayson Street (Historic Resource \#43). 


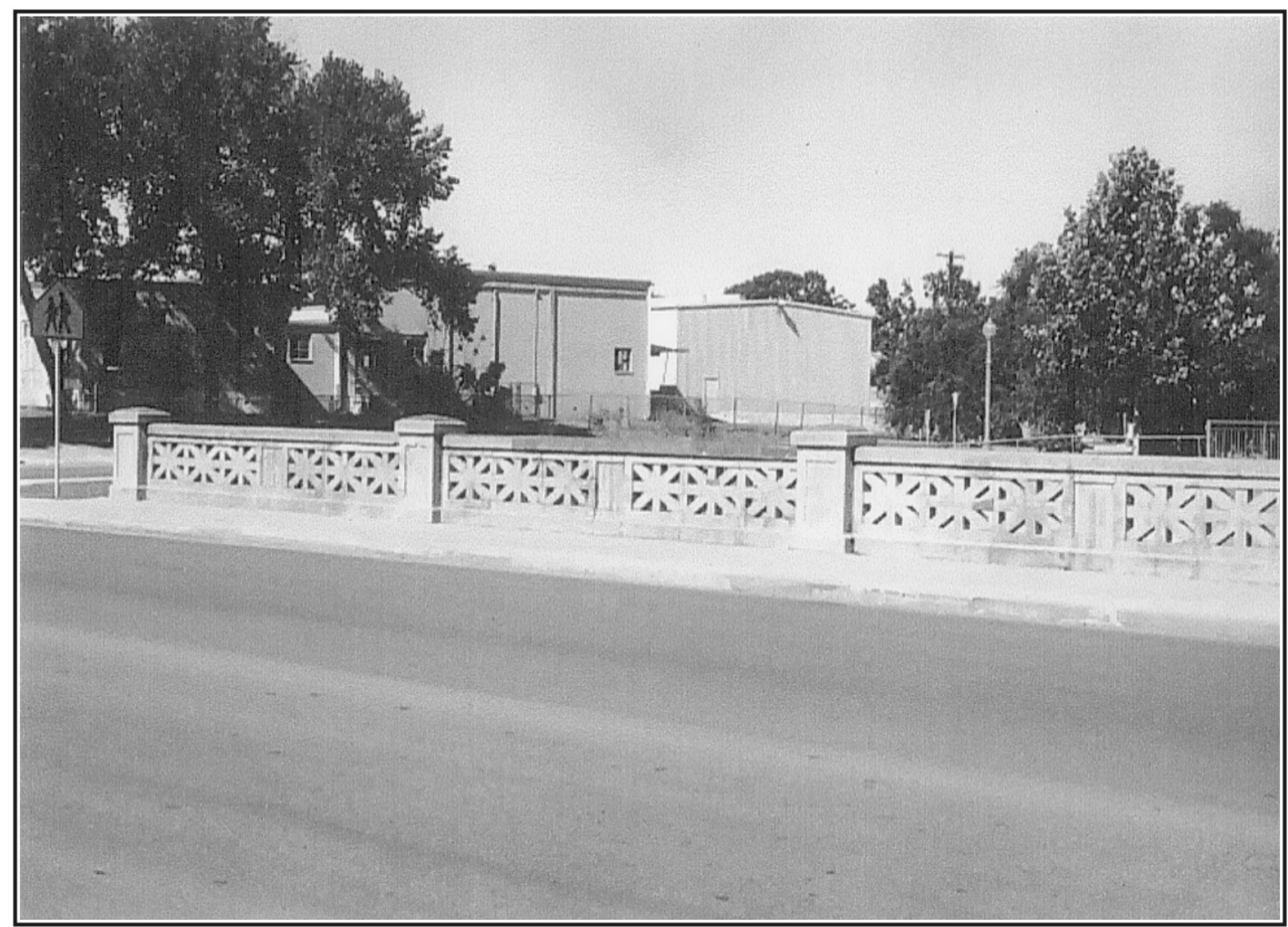

Figure 2-5. The Josephine Street Bridge located on Josephine Street (Historic Resource \#47).

Historic Resource \#48 is the iron bridge from the Lone Star Brewery and it was constructed 1901-1904 (Figure 2-6). The bridge served as pedestrian path between the two towers of the Lone Star Brewery. The bridge is a flat pratt trussbridge structure. The bridge was temporarily located at 102 Roy Smith (where it still stands) when the brewery became the San Antonio Museum of Art. The Lorenzo Ochs and George Aschbacher Brewery is depicted in a 1904 Sanborn map on the same property (Figure 2-7). This small San Antonio brewery only functioned from 1890 to 1904 (Texas Historical Commission [THC] 2006). According to deed records the land was conveyed to Ochs and Aschbacher in 1901 by W. Dobrowolski (BCC 2006a).

The Ninth Avenue bridge (Historic Resource \# 9), located in the 100 block of Ninth Avenue, has no known historic designation. It is a reinforced concrete bridge utilized for vehicle traffic. The bridge is of modern construction, exhibiting pedestrian sidewalks and steel railings.

The Newell Avenue bridge (Historic Resource \# 31), located in the 100 block of Newell Avenue, also appears to be of modern construction. The bridge consists of modern concrete pier construction with concrete railings with rectangular openings. On top of the concrete wall, pipe railings finish the walls of the bridge.

A wooden trestle bridge is located between Camden Street and IH-35 (Figure 2-8). It served the Texas Transportation Company and the date of construction is not known. The terminal railway company was chartered in 1897 and ran between the Galveston, Harrisburg, and San Antonio Railroad tracks and Pearl Brewery. This structure was not documented during the standing structure survey. 


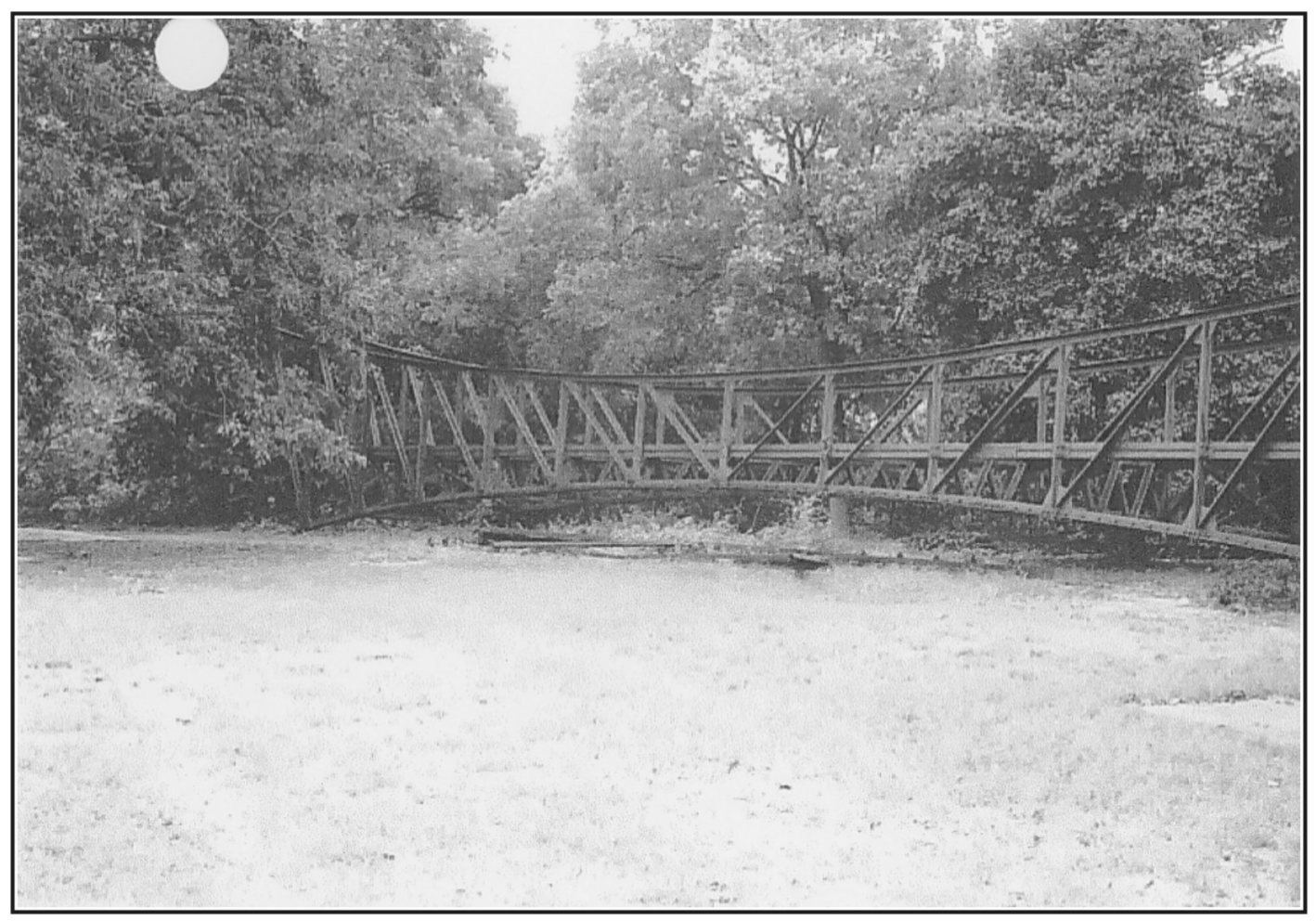

Figure 2-6. The iron bridge from Lone Star Brewery located on Roy Smith (Historic Resource \#48).

\section{Acequia Outflows (Desague)}

During the Colonial Period, the Franciscan missionaries took advantage of the abundant waters of the San Antonio River to construct elaborate irrigation networks of ditches or canals to water the extensive agricultural lands that dotted the river valley around the missions. Some of the canals, diversion dams, and even an aqueduct constructed by the Spanish are still visible and in use today. Unfortunately, the locations of portions of the elaborate irrigation system (acequias) have been lost over the years or at least have not been corroborated by archaeological excavations. Although the acequia system was very elaborate and consisted of miles of canals and numerous outflows and returns, only three outflow canals (desague) are known to have entered into the river in the vicinity of the APE. The outflows served as return channels from the acequias to the river for the purpose of irrigating additional land and for flood relief during periods of extreme high water or heavy rainfall. None of the acequias were relocated during reconnaissance efforts.
Two of the three outflow canals enter the river cutting across its eastern bank between East Grayson and Newell Streets. The northernmost of these outflows entered a large meander in the river while the other joined the river south of the meander in a section that has not been redirected through channelization. Channelization cut through the meander so that the northern outflow falls outside of the APE proper. The second outflow canal crossed the area that is currently part of the Pearl Brewery. The outflow canal enters the river at the apparent spot where a large sewer main exits the property and flows into the river. The third known outflow channel entered the river from the west in the area of the "Big Bend" adjacent the Molina Blanco. However, because this area was channelized, the modern channel and the APE are at some distance from the original entrance of the outflow channel into the river. That is, the location of the third and southernmost outflow is outside of the APE. While it was important to relocate and document the second acequia outflow near the old Pearl Brewery, no other specific effort was expended on finding additional, perhaps historically not discussed or mapped, acequia outflows outside of the APE. 


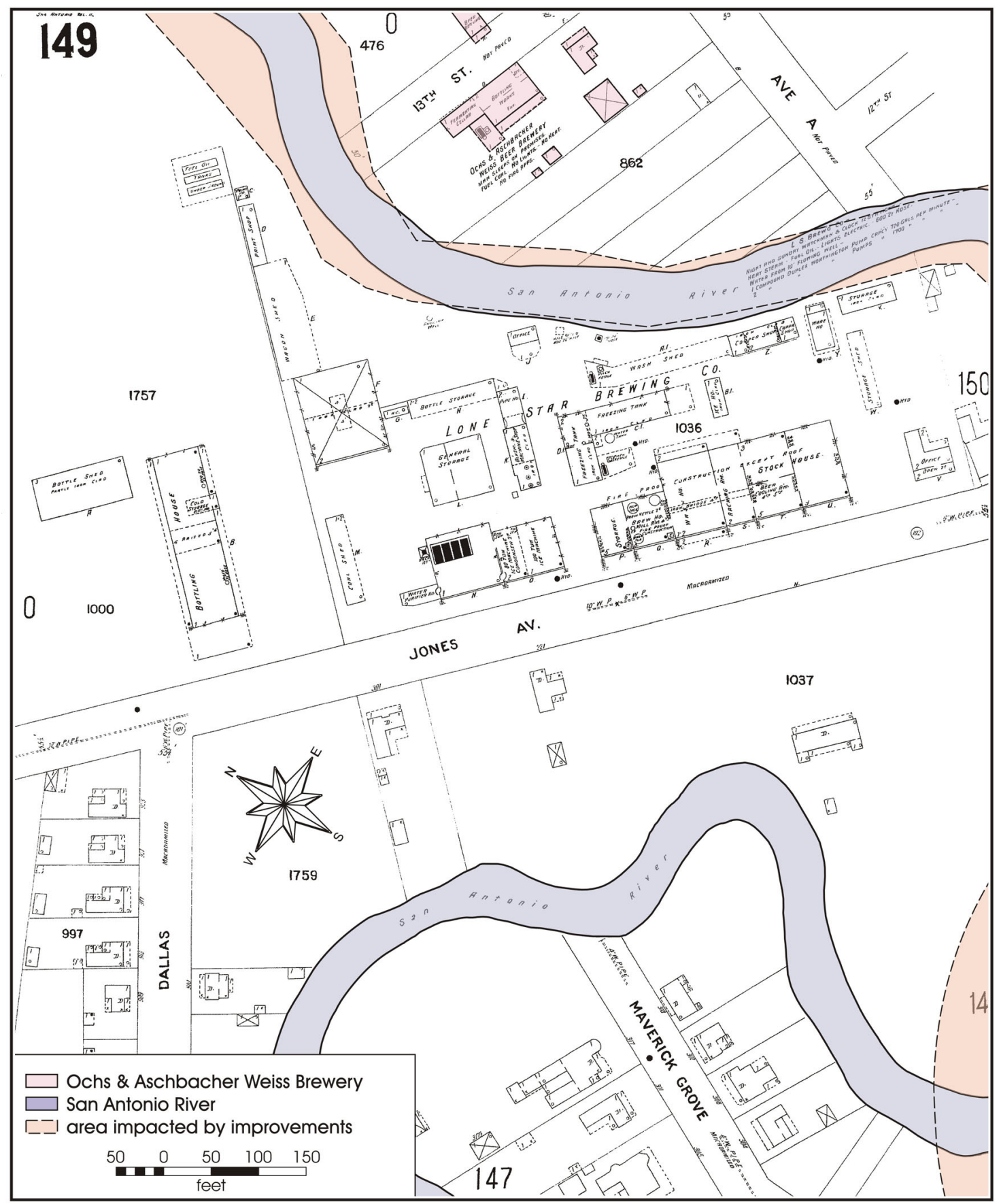

Figure 2-7. Sanborn map, dated 1904, depicting the location of the Ochs and Aschbacher Weiss Brewery. 


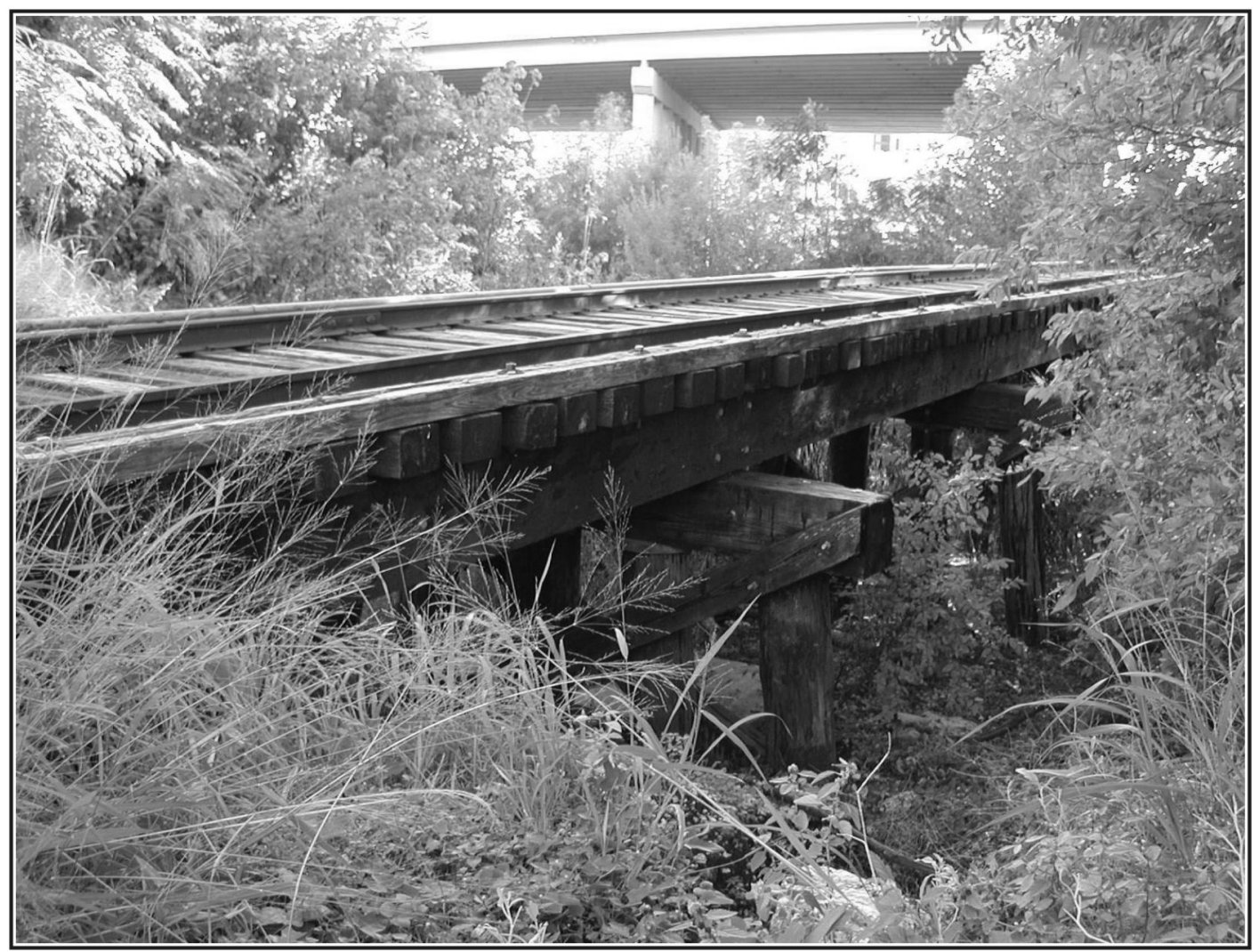

Figure 2-8. Wooden trestle bridge located between Camden Street and IH-35.

\section{Pearl Brewing Company (Historic Resource \#38)}

A significant local historic landmark is the Pearl Brewing Company, located in the northern portion of the project area on Pearl Parkway (Figure 2-9). In 1883 the San Antonio Brewing Association was formed by local business leaders. The J. B. Behloradsky Brewery was purchased and founded as the City Brewery. The signature brand of the Brewing Association, "Pearl," began being produced in 1886. By 1887 there was a four-story brew house, engine house, stables, cooperage, bottling works, and several other support structures. Beginning in 1902, the original brewery was replaced under the direction of Otto Koehler. By 1916 the brewery was the largest in Texas with a capacity of 110,000 barrels per year. The brewery was the only one in the state to survive prohibition. The San Antonio Brewing Company changed its corporate name to Pearl Brewing Company. The brewery closed its doors in July of 2000 (Hennech 1996:110; Leibold 2000). According to the historic resources inventory form provided by Mainstreet Architects (2005:Historic Resources Inventory Form \#38), "the brewery complex is comprised of a variety of masonry buildings of different scale and stylistic influences." The most dominant building and the one closest to the river is the nine-story masonry brewery with Second Empire influence.

\section{Lone Star Brewing Company (Historic Resource \#22)}

The old Lone Star Brewing Company (now San Antonio Museum of Art) is located at $230 \mathrm{~W}$. Jones Avenue (Figure 2-10). John H. Kampmann, a prominent San Antonio building contractor and financier, founded the Lone Star Brewing Company. The company was opened in 1884 and operated until 1892. Construction dates on the building range from 1884 to 1904 . The company was sold to Adolphus A. Busch, the famed St. Louis brewer. Prohibition laws affected the company's beer business so they began producing the soft drink "Tango." Prohibition ultimately caused the brewery to close. In 1921 it became the Lone Star Cotton Mill depicted on a 1922 Sanborn map (Figure 2-11; Walworth 2004). The Lone Star Ice and Food 


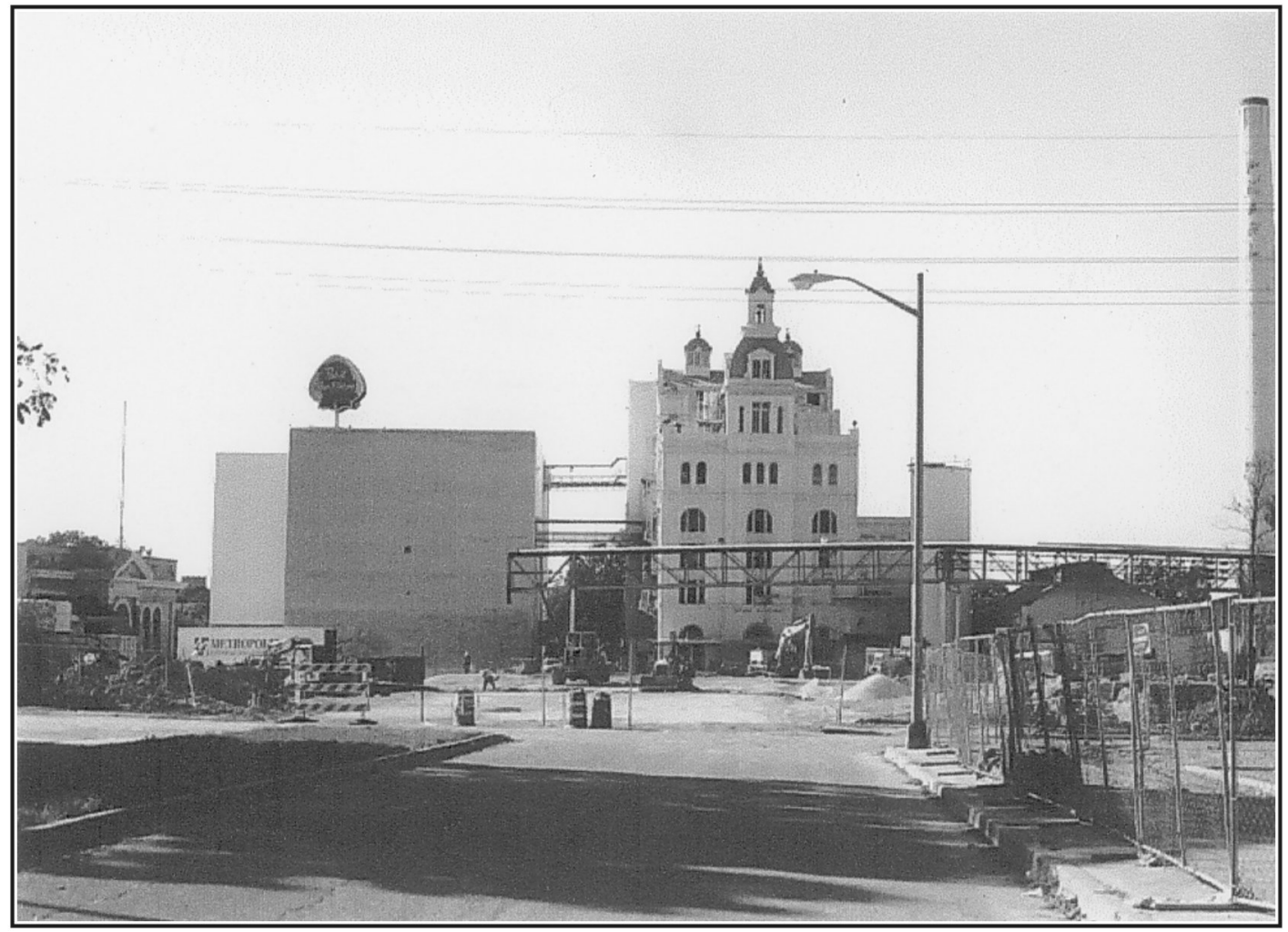

Figure 2-9. Pearl Brewing Company (Historic Resource \#38, east façade).

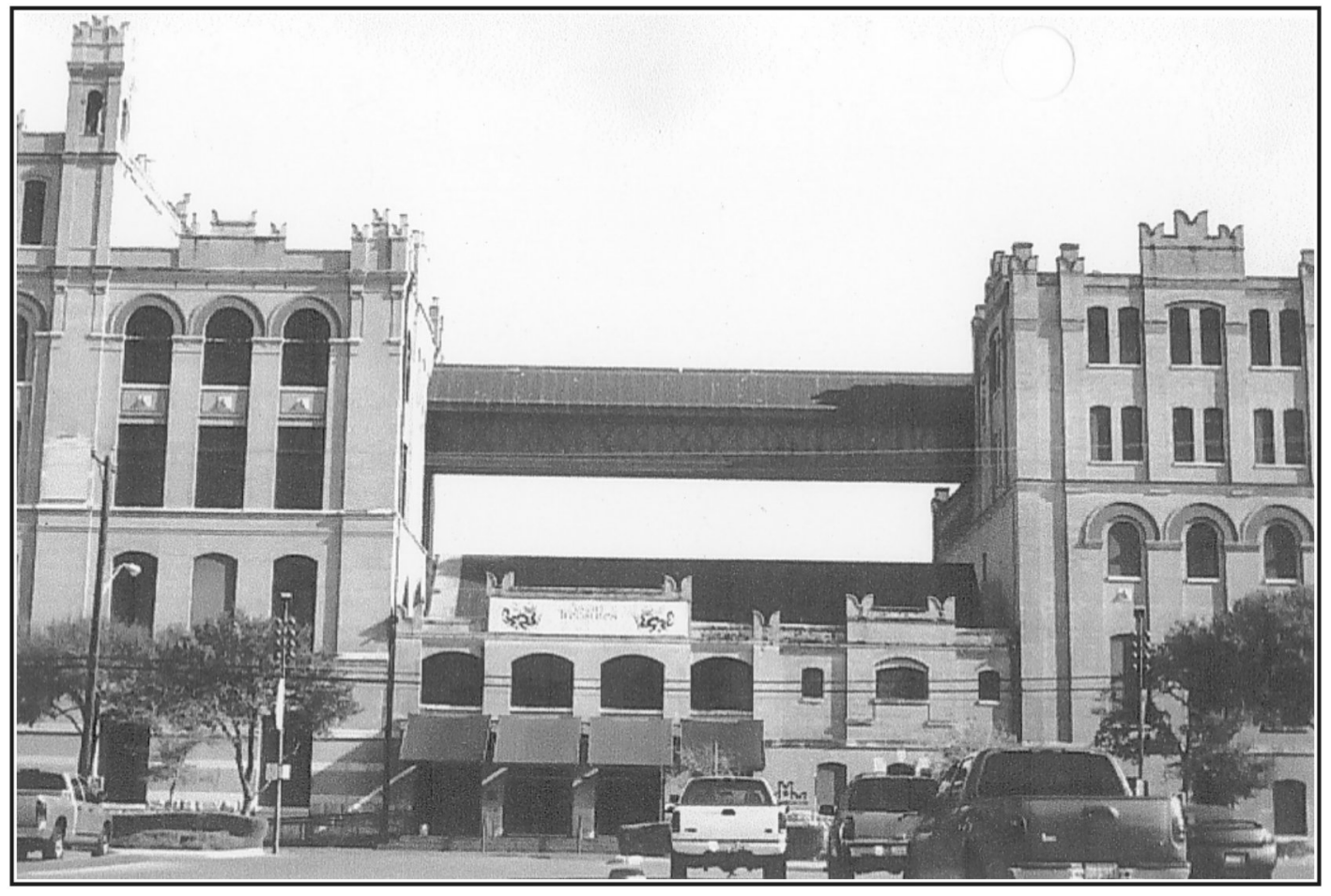

Figure 2-10. Lone Star Brewing Company (Historic Resource \#22, southwest façade). 
Company was in the building when the cotton mill closed in 1925 (Jennings 1998:261). The San Antonio Conservation Society saved the building and in 1981 the building was reopened as the San Antonio Museum of Art. The Lone Star Brewery was placed on the National Register of Historic Places in 1972.

The complex consists of load-bearing brick buildings ranging in height from one to five stories, with corbelled brick detailing, crenellated projections at the parapet, and arched openings. The original buildings of the brewery complex included a bath house, hops house, ice house, brewery, stables and a warehouse. There have been contemporary additions constructed since it became an art museum.

\section{Molina Blanco}

The Molina Blanco, a small gristmill constructed during the later part of the seventeenth century or early eighteenth century, is on a return channel of the Upper Labor acequia (Figure 2-1). It is located just west of North St. Mary's and north of Brooklyn Avenue. The property was not included in the standing structure survey, but it is a significant historic property and the Upper Labor acequia connected to the pre-channelized San Antonio River.

The suerte, or portion of land, was granted to Joseph Macario Zambrano as a shareholder on the initial channel of the Upper Labor on February 17, 1776 (BCC 2006b). Although the mill has been reported to have been constructed as early as 1733 , it could not have possibly been constructed until after 1733 (see Buck 1980:171-172; Cox et al. 2002; Jackson 1971:10).

Macario Zambrano and his wife Juana de Ocon y Trillo (or Oconitrillo) had ten children (Chabot 1937:196-197; Wright 1996:1140-1141). Of these, two figured prominently in early Texas history; José Darío (1768-1826), an ordained priest, joined his brother Juan Manuel (1772-1824) in the Royalist counter-revolution against the Casas Revolt in 1811. When the pastor of San Fernando Church was implicated in a revolutionary plot a short time later, José Darío was appointed to replace him. When the insurgents of the Guetiérrez-Magee occupied San Antonio, José Darío again joined the Royalist forces and served as one of their chaplains (Wright 1996:1140-1141). The little mill gained lasting fame in 1835 when it became the assembly point for the forces under Ben Milam during the Siege of Bexar.
In November of 1839, James W. Robinson purchased the mill from the estate of Juan Manuel Zambrano with the intent to put the old mill back into operation; however, there is no evidence that this was ever done (BCC 2006c).

In 1851, the land was conveyed by Miguel Yndos (Indos), a Zambrano heir, to José Luis Carabajal and his wife Mariá de Jesus Flores. They, in turn, sold the property for $\$ 700$ to Warwick Tunstall in June of 1854 (BCC 2006d). Tunstall, a native of Kentucky, had arrived at that time with his first wife, Mary, and later married Florida Boswell, a widow, in 1848. He had a large, two-story home constructed near the mill ruins by noted local architect John Fries (Chabot 1937:338; Long 1996:4-5). Their daughter Ethel, wife of Harry P. Drought, later inherited the property. They constructed their home on the property near the turn of the century. In July of 1950, Ethel conveyed the property to the Sisters of Divine Providence for the site of Central Catholic High School (BCC 2006e). This home, now the 1200 block of North St. Mary's Street, is currently under restoration as a guesthouse for the order.

\section{Standing Structures Predating 1955}

Historic Resource \#1B is listed as a drain enclosure located underneath the Lexington Avenue Bridge. The drain enclosure is a 6-ft.-high rubble rock wall surrounding the drain. The bridge itself was constructed in 1929, though no date is known concerning the origin of the drain enclosure.

Historic Resource \#2 is the Clarion Fiesta Riverwalk Hotel. The El Tropicano Hotel purchased the property from R. E. Dumas Milner in 1962 (BCC 2006f). The hotel construction commenced that same year. It appears to be the first hotel constructed on the banks of the San Antonio River. By 1989, El Tropicano filed bankruptcy, later selling the property to Karim Hospitality, Inc. (BCC 2006g). In 1996, Karim Hospitality, Inc. sold the property to Preferred Riverwalk L. P. (BCC 2006h). The hotel was conveyed to La Salle Bank in August of 2004. By March of 2005, the hotel was under new ownership and renamed the Fiesta Riverwalk Hotel (BCC 2006i). The concrete slope associated with the hotel, listed as Historic Resource \#3, is likely to have been constructed after it was purchased by El Tropicano, though deed records make no indication of the origin of the slope.

Historic Resource \#10 is located at 815 Avenue B and was constructed in 1935 (Figure 2-12). Currently, the building is used as covered parking for the AT\&T building. Deed 


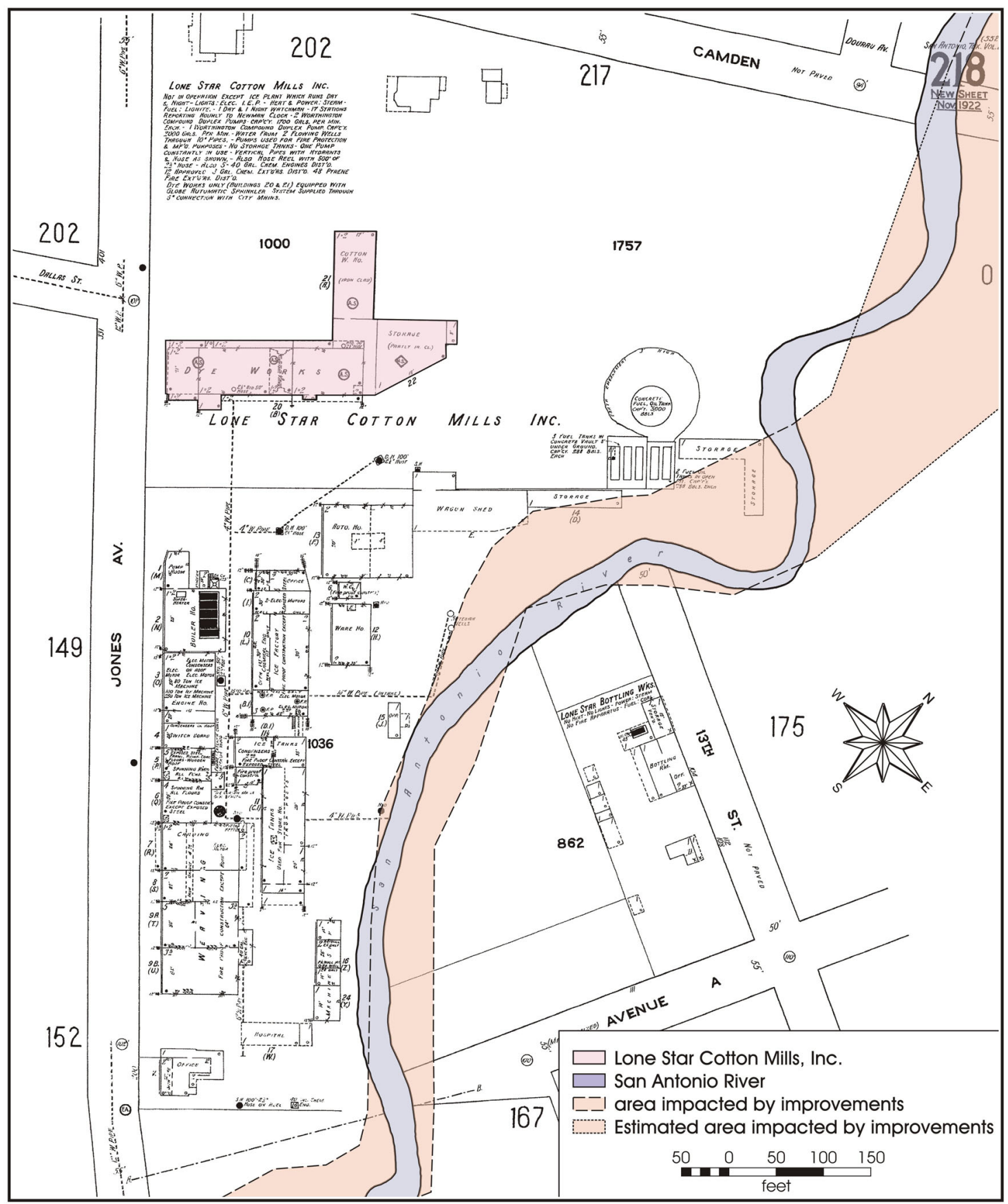

Figure 2-11. Sanborn map, dated 1922, depicting the location of the Lone Star Cotton Mills, Inc. 
records indicate that prior to $\mathrm{SBC}$ ownership, the property belonged to Belle Rive Investments (BCC 2006j). The earliest deed encountered is dated 1943 when Southwestern Greyhound Lines, Inc. conveyed the land to Corona Realty (BCC 2006k). According to several deeds, C. W. Carroll and Leo Picard were business associates and trustees of the Universal Book Bindery Profit Sharing Retirement Plan. Carroll was also the president of Corona Reality. A 1911 Sanborn map depicts a bookbinding facility where the property is located (Figure 2-13). The Crystal Ice and Manufacturing Company is depicted on an 1896 Sanborn map of this property (Figure 2-14; Sanborn Maps 2006: Sheet 51). In 1887, an artesian well that supplied large quantities of pure, clear water was drilled on the property (Schuchard 1951:36). Crystal Ice and Manufacturing Company was sold to Ben T. Cable in November of 1900 (BCC 20061). Cable sold the property to the Artesian Ice Company in August of 1901 (BCC 2006m). According to deed records, the Artesian Ice Company was conveyed to Van Petty in 1907 (Figure 2-15; BCC 2006n). The building complex was located at the end of a mill race connecting back to the San Antonio River. A mill race is the fast-moving stream of water that drives a mill wheel (Answers.com 2006). On the 1896 Sanborn map the mill race is shown running in a southwest-northeast direction. It began at the San Antonio River just northwest of Tenth Street and terminated at Eighth Street, where the pre-channelized river meandered. There might have been a mill along the mill race course prior to the ice plant.

It is possible that the ice plant utilized a Carré absorption machine to manufacture ice. The machine utilized ammonia, which it heated and passed into a coil over which a large amount of cool water flowed, lowering the ammonia's temperature to as low as $-27^{\circ} \mathrm{F}$, therefore effectively freezing water from the artesian well. It appears the race may have provided the cool water from the river to pass over the heated ammonia. The mill race does not appear on the 1911 Sanborn map, indicating there may have been a change in the ice manufacturing technique.

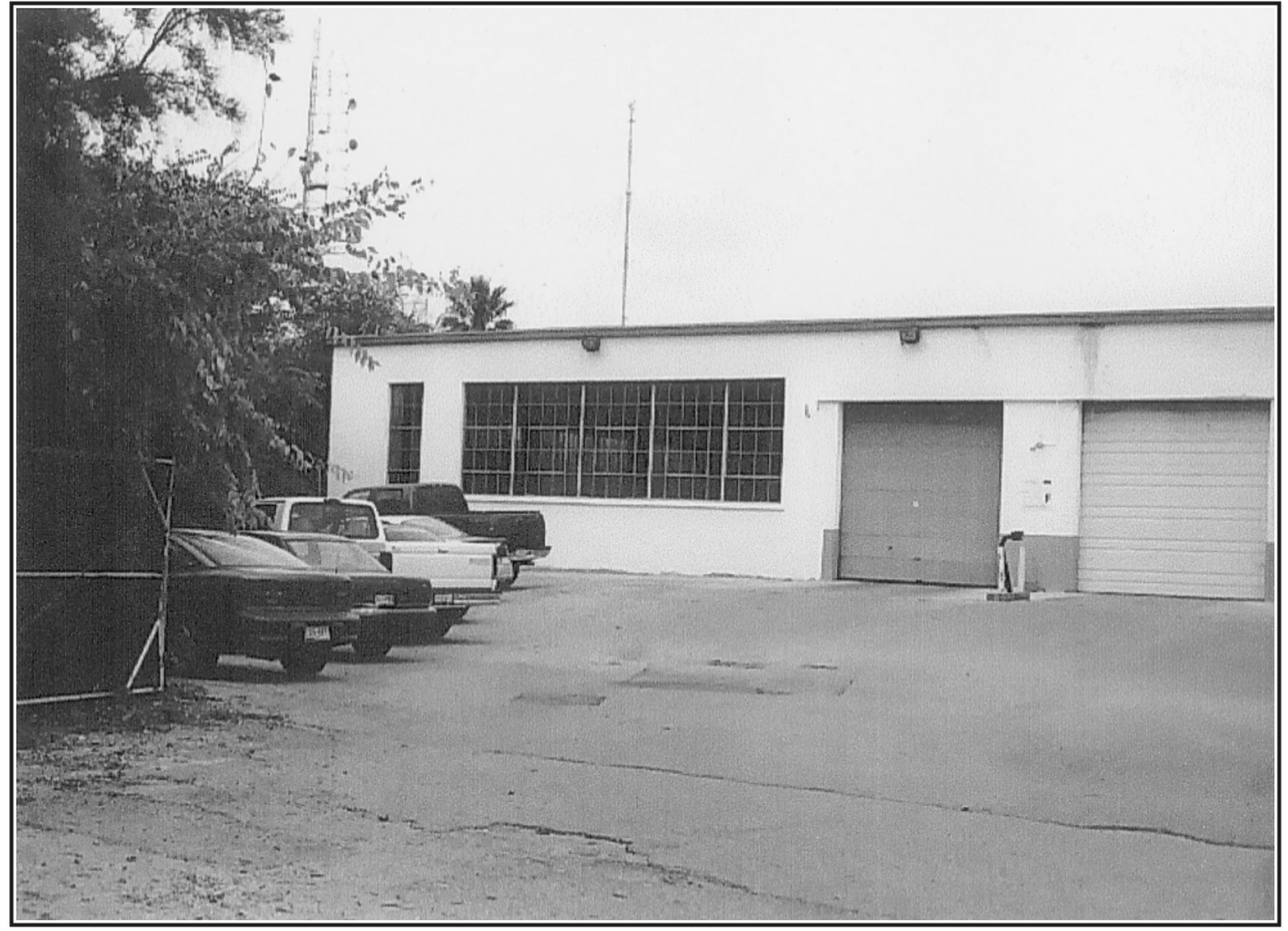

Figure 2-12. Historic Resource \#10 located on Avenue B (southwest façade). 


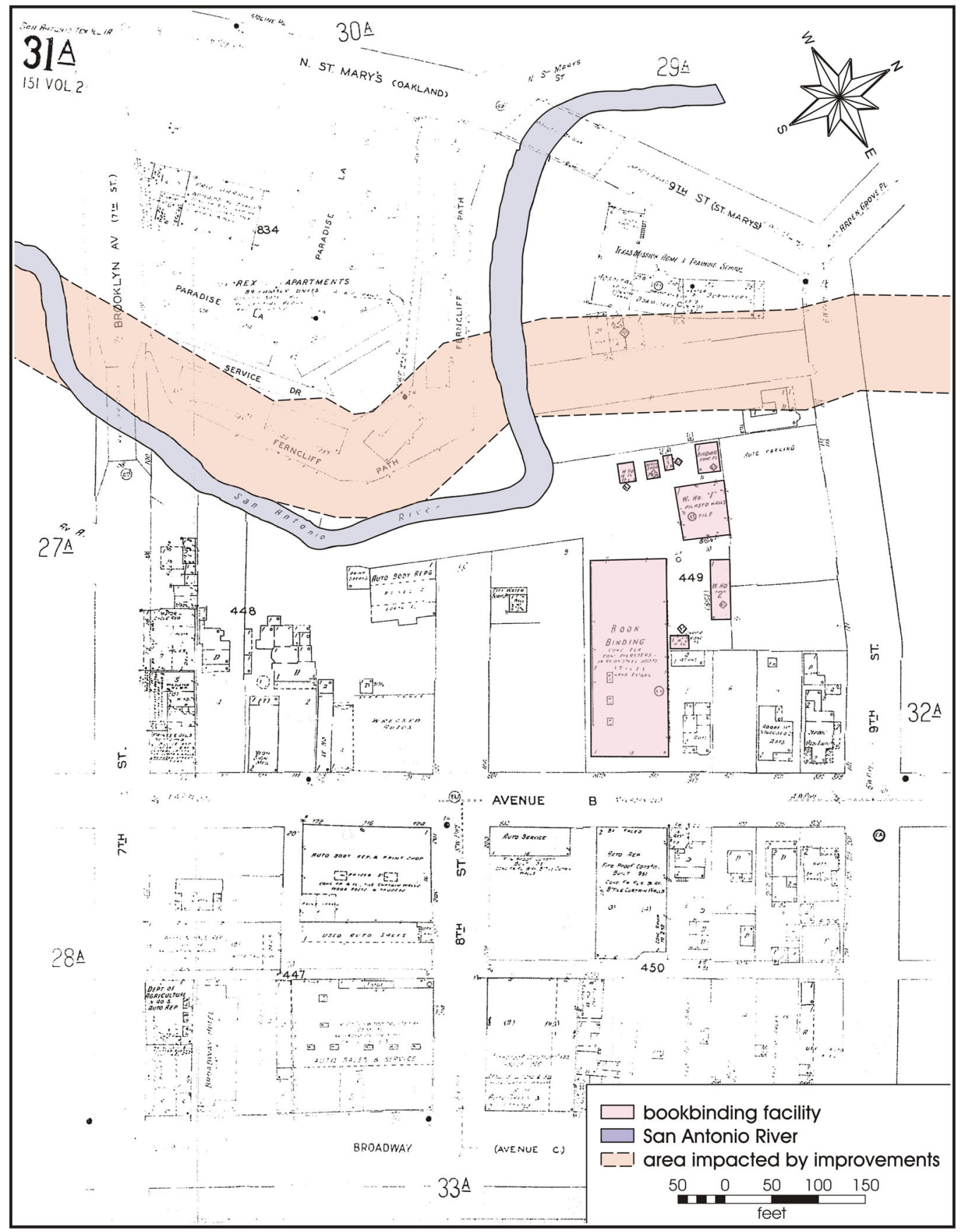

Figure 2-13. Sanborn map, dated 1911, depicting the location of the bookbinding facility. 


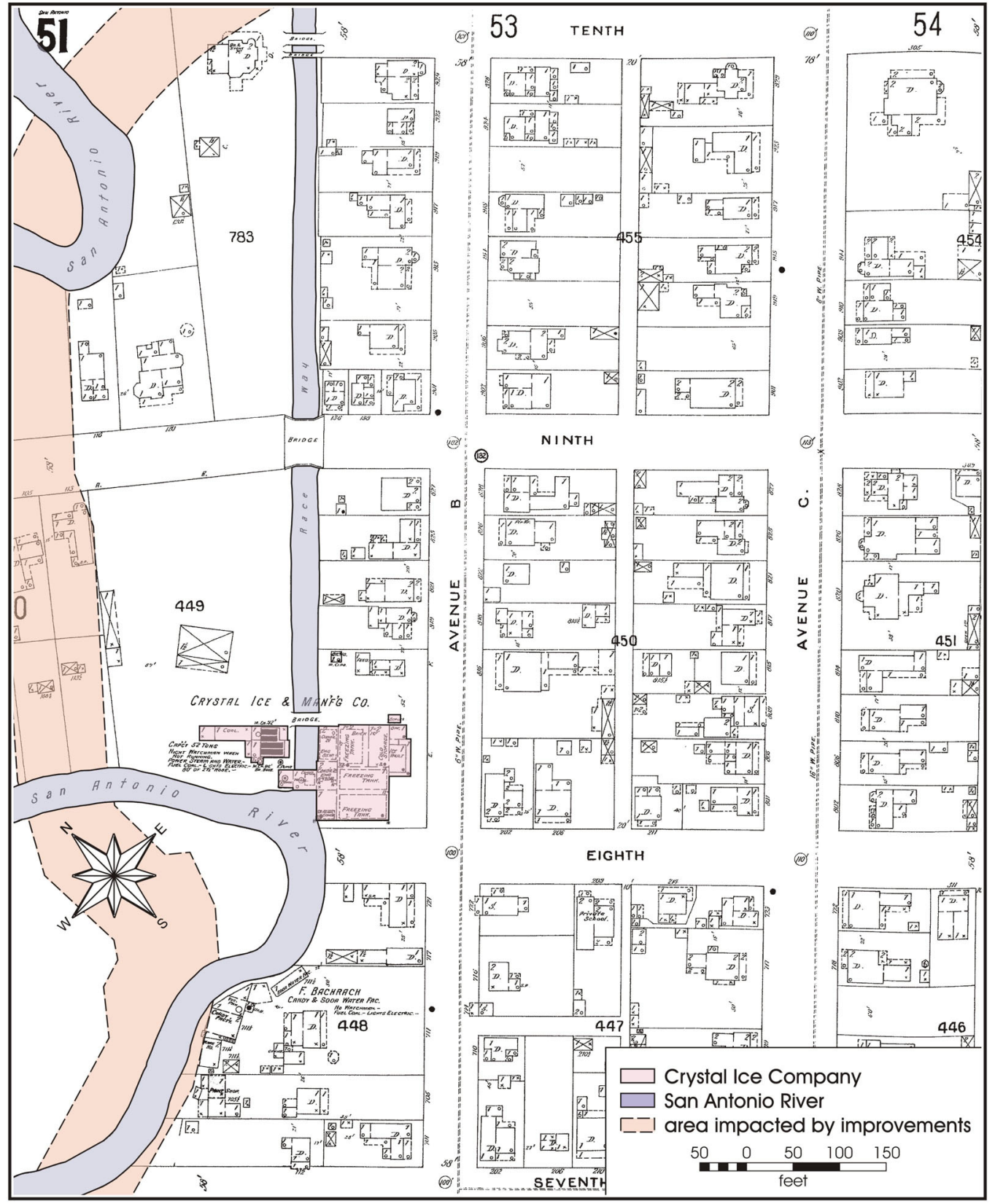

Figure 2-14. Sanborn map, dated 1896, depicting the location of the Crystal Ice and Manufacturing Company. 


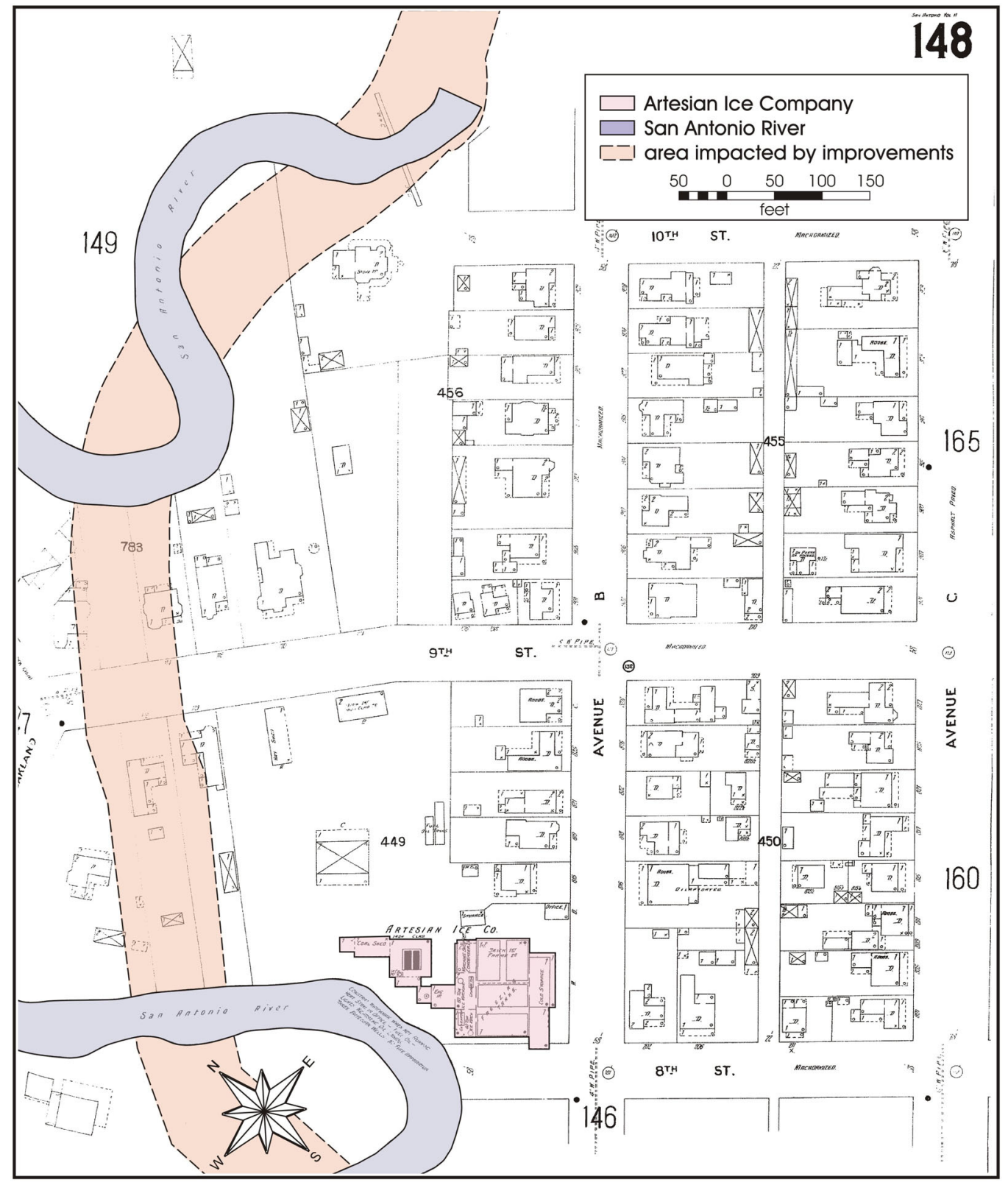

Figure 2-15. Sanborn map, dated 1904, depicting the location of the Artesian Ice Company. 
The current building has a single-story with an open plan. It has a low slope roof that has a painted finish over concrete blocks and clay tile. The east facade of the building is a two-tone brick with diapering above the windows.

Historic Resource \#11 is located at 120 Ninth Street (Figure 2-16). According to the historic resources inventory provided by Mainstreet Architects it was constructed around 1940. A plaque found on the interior of the structure reveals that architect Marvin Eickenroht constructed the building in 1939. Annie L. Henry, Ernest L. Brown, and Clinton G. Brown, all heirs of the J. N. Brown estate, conveyed the property to Turner's, Inc. sometime in 1939 (BCC 2006o). A portion of the property had been owned by J. N. prior to 1909, and V. A. Petty conveyed the remainder to him in that year (BCC 2006p). The resource consists of a singlestory commercial building with a rectangular two-part plan. The southwest portion of the building (facing the river) has clay tile with a concrete base. Though the window openings have been filled with concrete blocks, the cast lintels and sills are remaining. There is one overhead door at the dock. The western portion of the south façade is brick with distinctive art deco detailing and brick banding, and a recessed entry. The eastern portion is covered with metal panels and louvers at the base of the building. The southeast wall is brick with steel casement windows and a rowlock sill. The northern portion of the southeast wall has wood, double-hung windows and metal attic vents. A small clay tile addition projects from the building at its northernmost end. This property is currently being utilized as a bowling alley.

Historic Resource \#13 is located on 10 Tenth Street (Figure 2-17). The building was constructed ca. 1896 and currently functions as VFW Post 76. It is a two and a half story shingle style house with strong classical porch details. The house has a hipped roof with cross gables and asphalt shingles. It is located in the "Irish Flats" and served as the brew master's house for the Lone Star Brewery. It began as a dome-shaped residence and was the largest estate in San Antonio as of

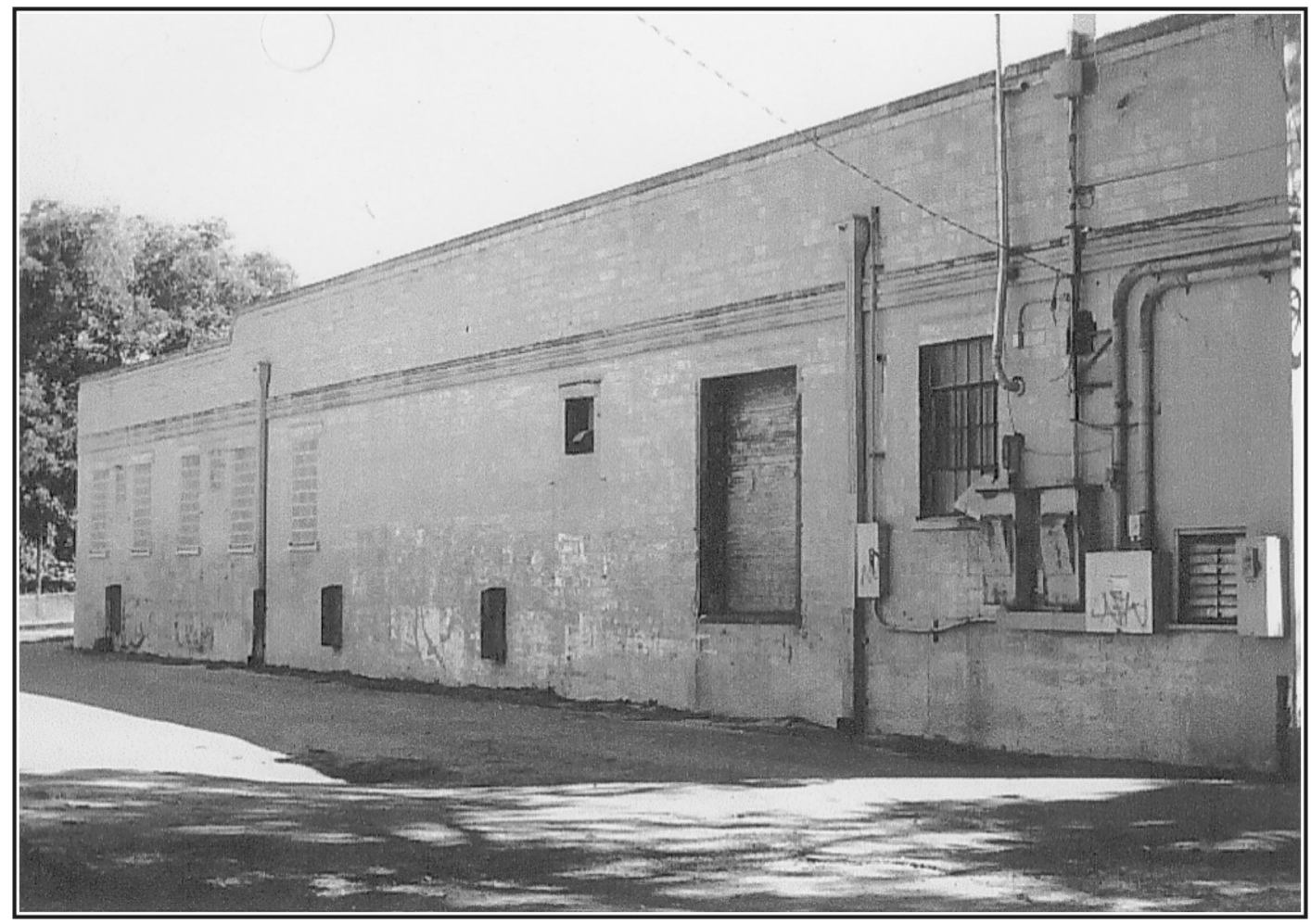

Figure 2-16. Historic Resource \#11 located on Ninth Street (north façade). 
1936 when a second-story balcony was added. Mr. Van Petty built the original house with 17 rooms and five bathrooms. The structure was deeded to the VFW Post in 1947.

The "Irish Flats" was settled by Irish immigrants that had moved to San Antonio in the mid-1800s. The "Irish Flats" consists of the area bounded by Alamo Plaza and Houston Street on the south, Avenue C on the west, Sixth Street on the north and the Acequia Madre on the east (Salsa.net 2006). The houses in this area of San Antonio were usually flush to the street with narrow front porches, low ceilings, limestone walls, and thatch roofs (later replaced by shingles or tin). The styles of the houses in the "Irish Flats" were based on homes the immigrants left in Ireland, as well as some ideas borrowed from local Spanish and German styles.

Bexar County deed records indicate the land was deeded to the Sam Houston VFW Post 76 on June 20, 1947, from Dabney E. Petty (BCC 2006q). The land was passed on to Dabney E. Petty from Van Petty, the builder of the brew master's house. An affidavit of adverse use states that the land was "part of the remaining portion of the Alamo Mill
Race, a 27.78-ft.-wide strip of land described in a deed dated October 3, 1878 to Stahl, Geddes, and Jones from George M. Maverick" (BCC 2006r). An 1896 Sanborn map (Sheet 51) depicts a mill race along the eastern portion of the property (Figure 2-14). This is the same mill race that ran along the property where Historic Resource \#10 is located.

Historic Resource \#14 has been identified as a fallout shelter on the property at 206 Arden Grove. Deed research did not identify the date of construction of the fallout shelter. Rudolph and Adelpha Quinones purchased the property in September of 1964. No additional records were encountered indicating the ownership prior to the Quinones. The Quinones conveyed the property to Arden Grove Corporation in September of 1967. Arden Grove Corp. later became Manion-Arden Grove Ltd. Manion-Arden Grove conveyed the property to Joe Rainey Manion in December of 1992. Fallout shelters became popular after the end of WWII when individuals became wary of the possible threat of nuclear attack. The height of the popularity of such fallout shelters/bomb shelters was during the 1950s and 1960s. Community fallout shelters were established in most

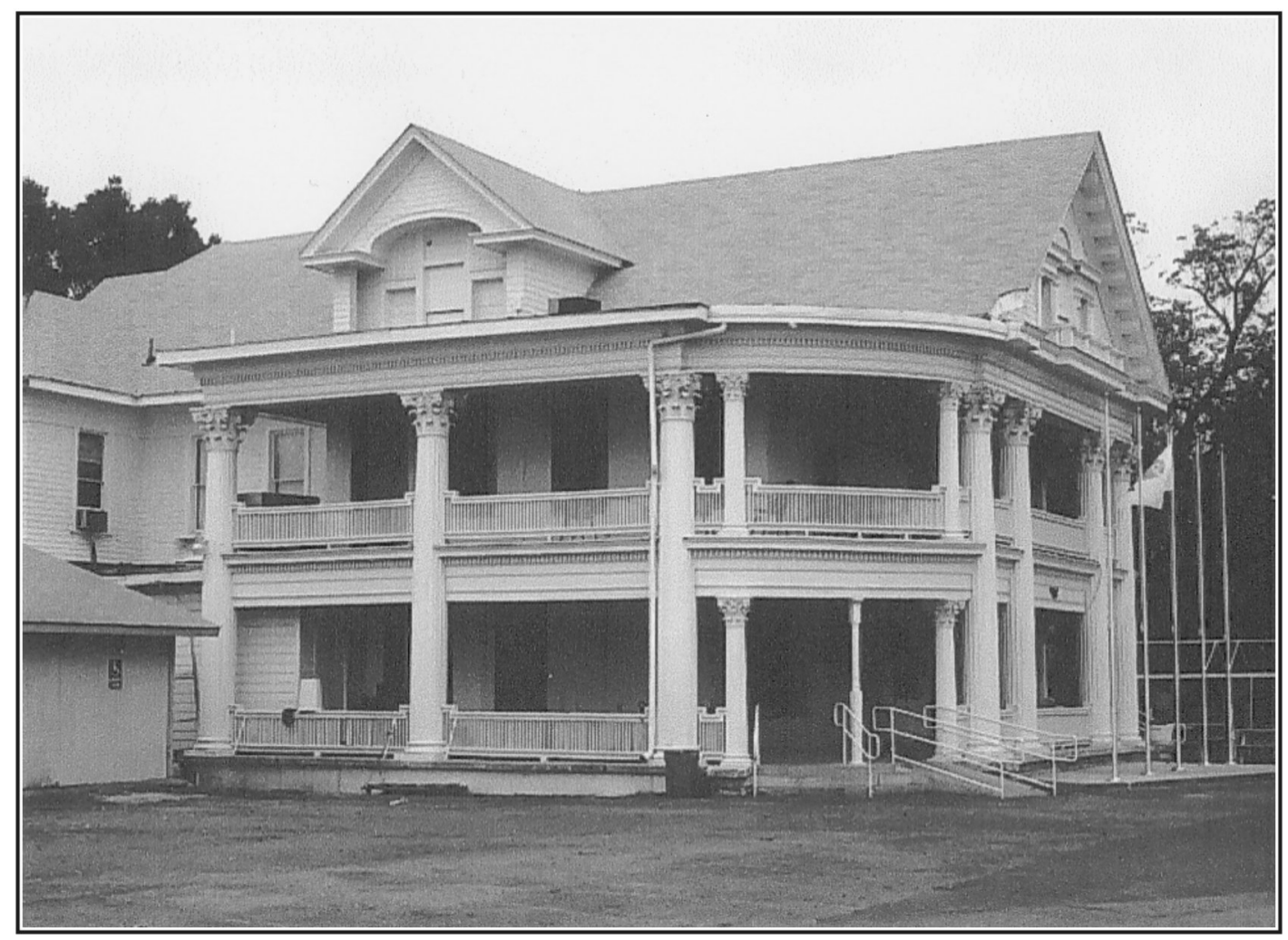

Figure 2-17. VFW Post 76 and former residence of the Lone Star Brewery brew master, located on Tenth Street (Historic Resource \#13). 
communities and were stocked with provisions to support the stated capacity of each shelter. Structures that contained fallout shelters can be found all over Texas today. Each would be marked with a plaque indicating that a fallout shelter was within. Examples of these can presently be found at the old Community Savings Building in Fredericksburg, Caldwell Elementary School in McKinney, several public buildings in and around the Dallas area including a fire station, and Baylor University has one on campus in one of the science buildings. The community shelters were constructed during the early 1950s and some continued to be constructed up until the 1980s (Marten 2006). Little information is known concerning individual shelters, but it would appear that Historic Resource \#14 was constructed either by the Quinones, or by a previous owner. It does not seem likely that a corporation would construct a shelter of this size on one of their business properties.

Historic Resource \#16 is located at 1033 Avenue B and was constructed ca. 1945 (Figure 2-18). It is a single-story, rectangular, commercial building of concrete block construction with a low slope, built-up roof with parapet on three sides. At the time of its construction, Lloyd and Elma Hamm were the owners of the property (BCC 2006s). There is a single-story, concrete block addition with a low slope roof. Slight overhangs exist at the riverside portion of the building. Currently, the building is utilized as a lounge and its historical use is unknown.

Historic Resource \#18 is located at 1013 Avenue B and was constructed ca. 1945 (Figure 2-19). The deed search of the property revealed that the building would have been built when L. K. and Elma Hamm owned the property (BCC 2006t). The structure is a single-story commercial building with a rectangular plan. It is clad with grooved plywood panels over unknown original material. It has an aluminum and glass storefront that is recessed from the front façade.

Historic Resource \#19 is located at 1011 Avenue B and was constructed ca. 1912 (Figure 2-20). The building currently functions as a bar, but it was originally utilized as a residence. Deed records indicate that Van Petty owned the property from 1910 to 1926 (BCC 2006u). David Logan conveyed the property to Van Petty by 1910 , and it is

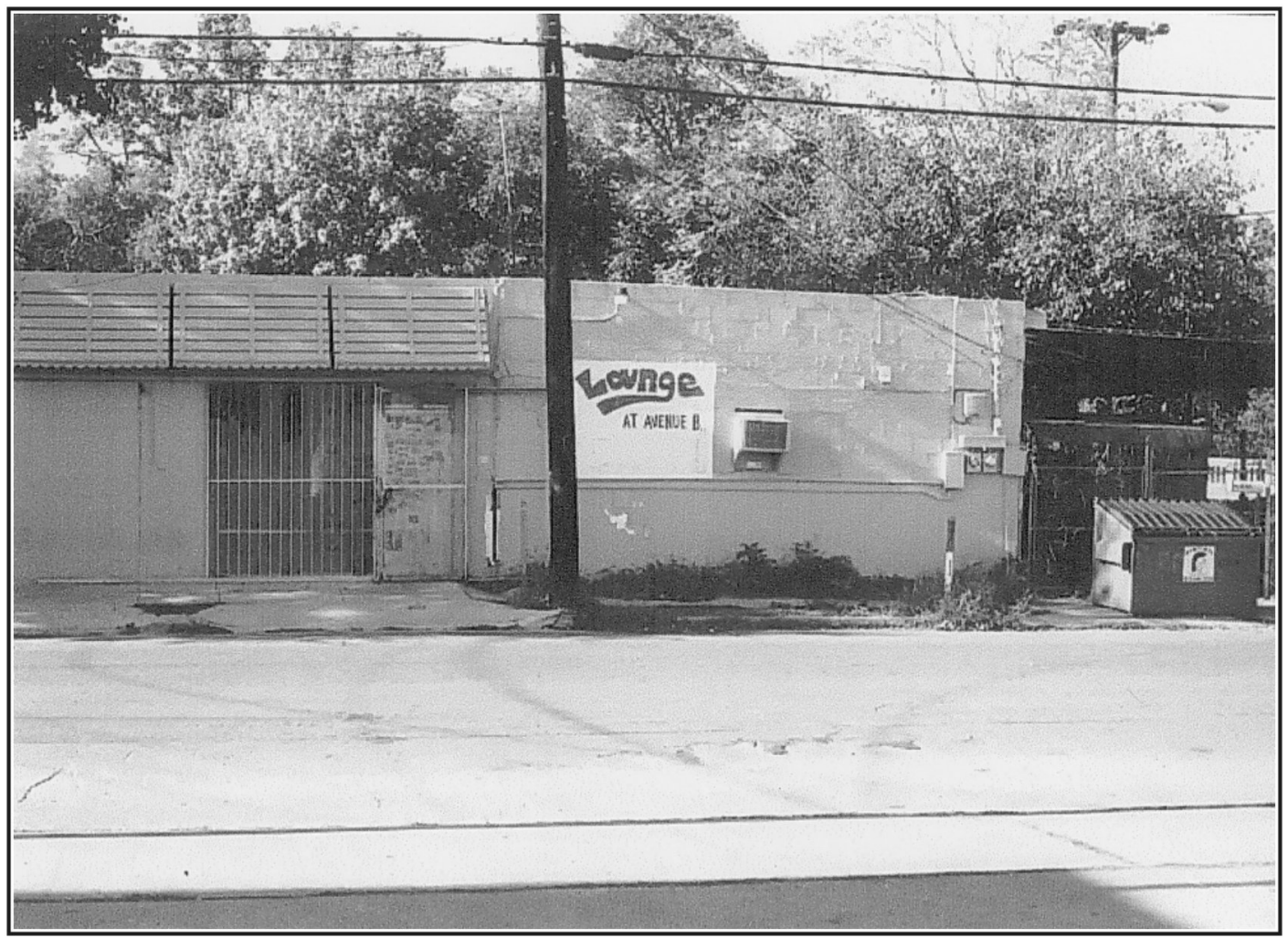

Figure 2-18. Historic Resource \#16 located on Avenue B (southeast façade). 


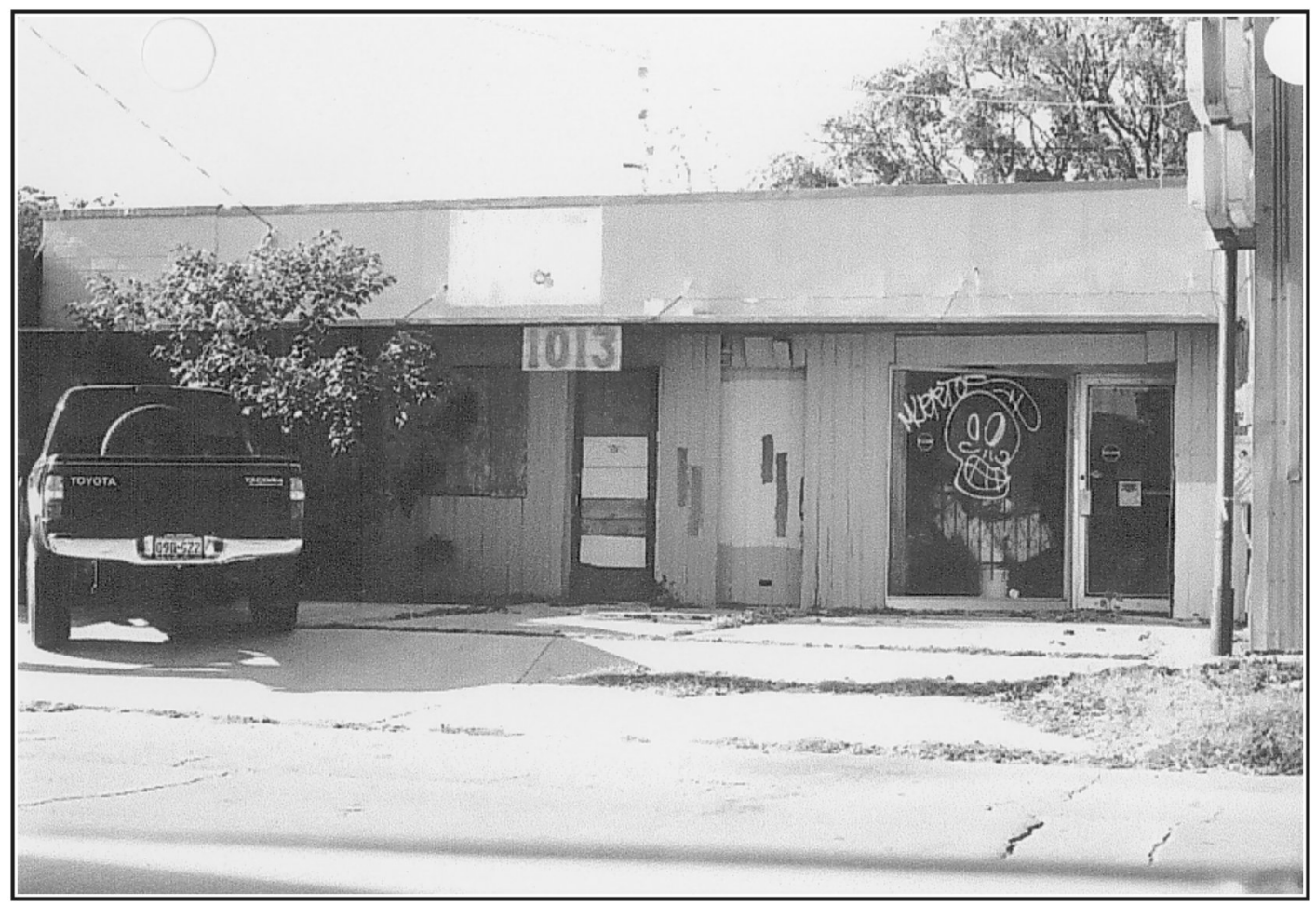

Figure 2-19. Historic Resource \#18 located on Avenue B (southeast façade).

possible the building was constructed while the property was in the hands of either individual. It is constructed of concrete block and has a square plan. It has a concrete foundation and a low slope roof with no overhang. The façade facing the street originally had two entrance doors but one is currently boarded shut. A rowlock sill is still visible and a window on the north side remains intact. A wood-supported canopy runs the width of the building.

Historic Resource \#20 is located at 1005 Avenue B and was constructed ca. 1900 (Figure 2-21). Historic Resource \#21 is located at 1001 Avenue B and was also constructed ca. 1900 (Figure 2-22). It appears that Historic Resources \#20 and \#21 were owned by Francis Smith prior to 1901 (BCC 2006v). David Logan was the property owner from 1901 to 1910 (BCC 2006v). Both houses have a singlestory, square plan with a front porch and a two-story tower on the left side. The architectural elements are executed in a Craftsman bungalow style. This style was prevalent during the early 1900s. The buildings are wood-framed with pier and beam foundations. The façades are composed of wood drop siding. There is an imitation limestone veneer approximately $3.3 \mathrm{ft}$. high.
Historic Resource \#26 is located at 201 Avenue A and was constructed ca. 1945 (Figure 2-23). The property has three freestanding buildings arranged in a clustered pattern. In the Bexar County Appraisal District records, two improvements were recorded: One improvement was added in 1945 and is described as a wood warehouse; the other improvement was dated 1955 and consisted of a masonry warehouse. The Mainstreet Architects inventory form for this historic resource only included the metal buildings, not the masonry or wooden resources. In 1945, the property belonged to Dabney Petty (BCC 2006w). The property was conveyed to Earl Denson in 1947 (BCC 2006x) and thereafter to F. P. Elizondo (BCC 2006y). Elizondo may have been the owner of the property in 1955 when the masonry warehouse was constructed.

Building \#1 is a single-story, rectangular metal building with a corrugated metal gable roof with a slight overhang. It has a fixed metal frame with six- and nine-pane sash windows and large sliding wood doors. Building \#2 is a metal rectangular mobile home. Building \#3 is a metal Quonset hut with a block false front and an arched, corrugated metal roof and elevated concrete slab foundation. 


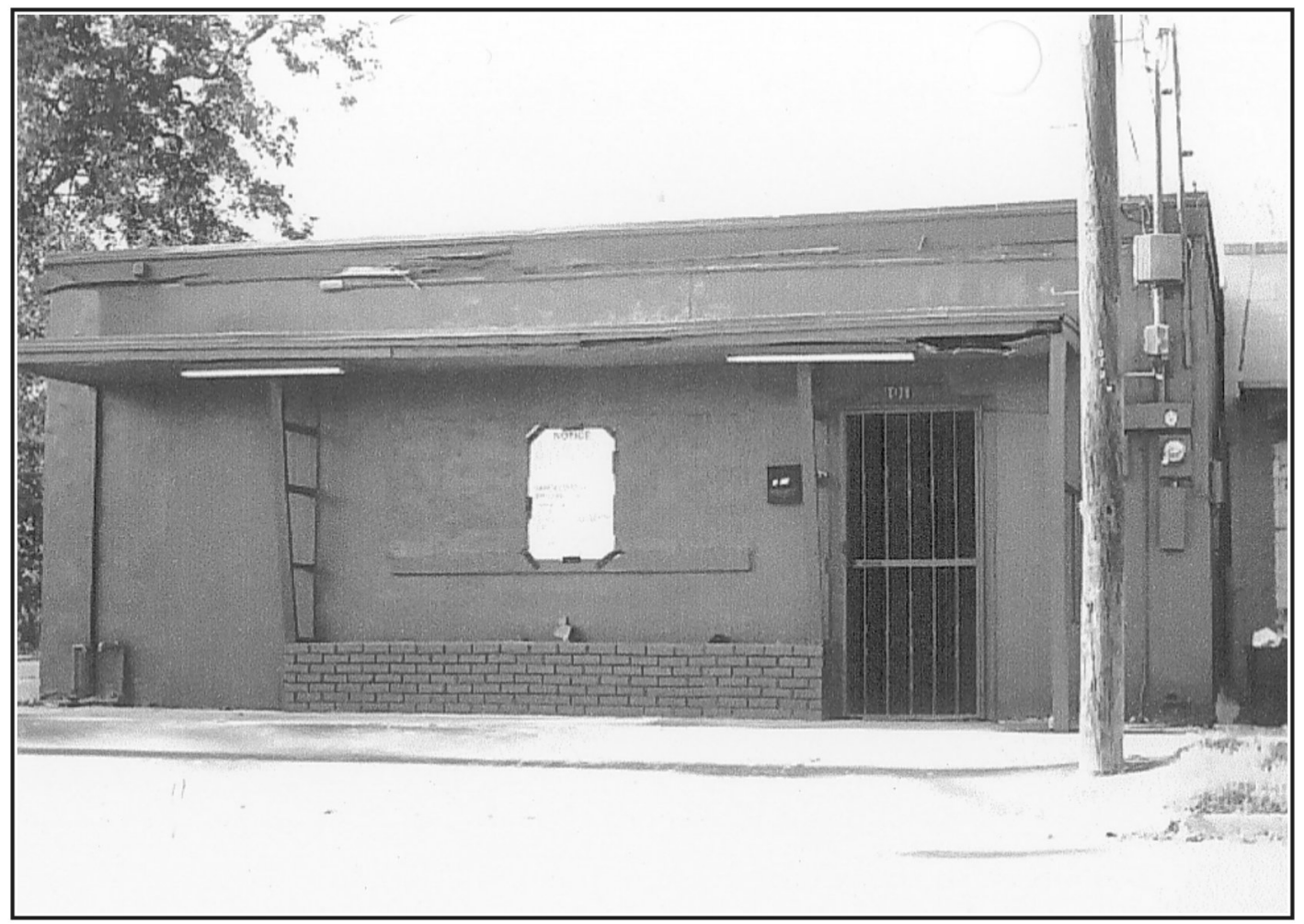

Figure 2-20. Historic Resource \#19 located on Avenue B (southeast façade).

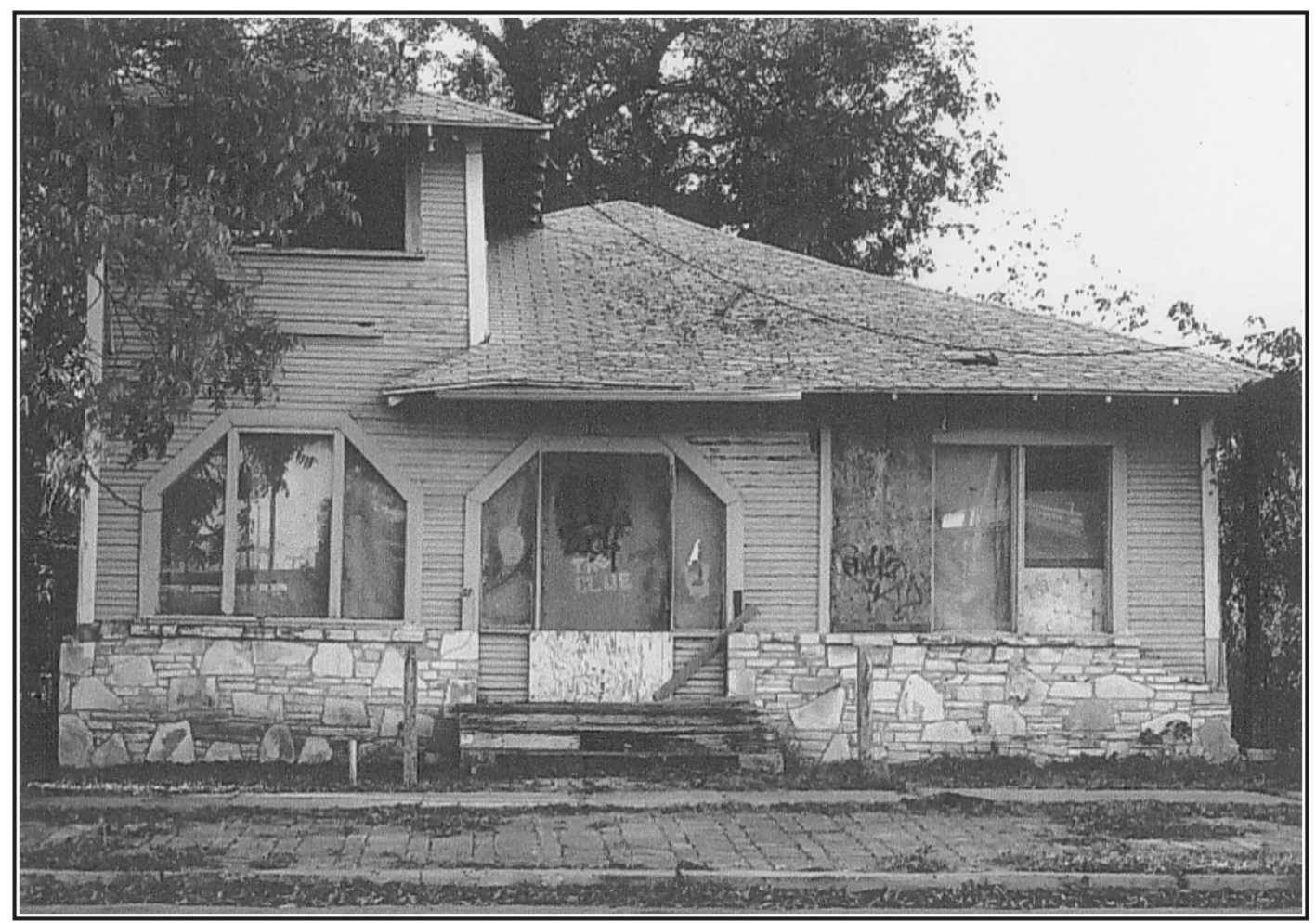

Figure 2-21. Historic Resource \#20 located on Avenue B (southeast façade). 


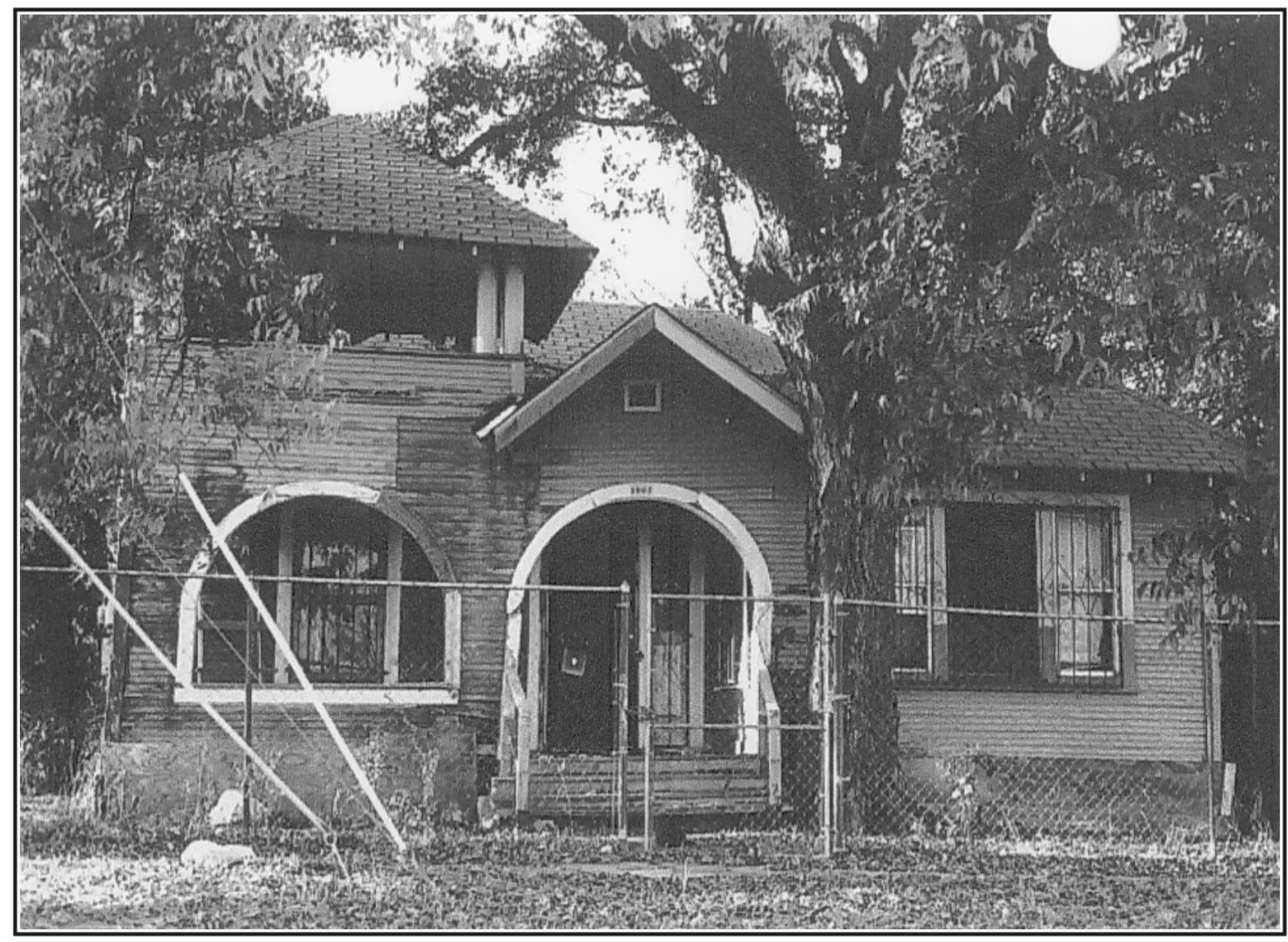

Figure 2-22. Historic Resource \#21 located on Avenue B (southeast façade).

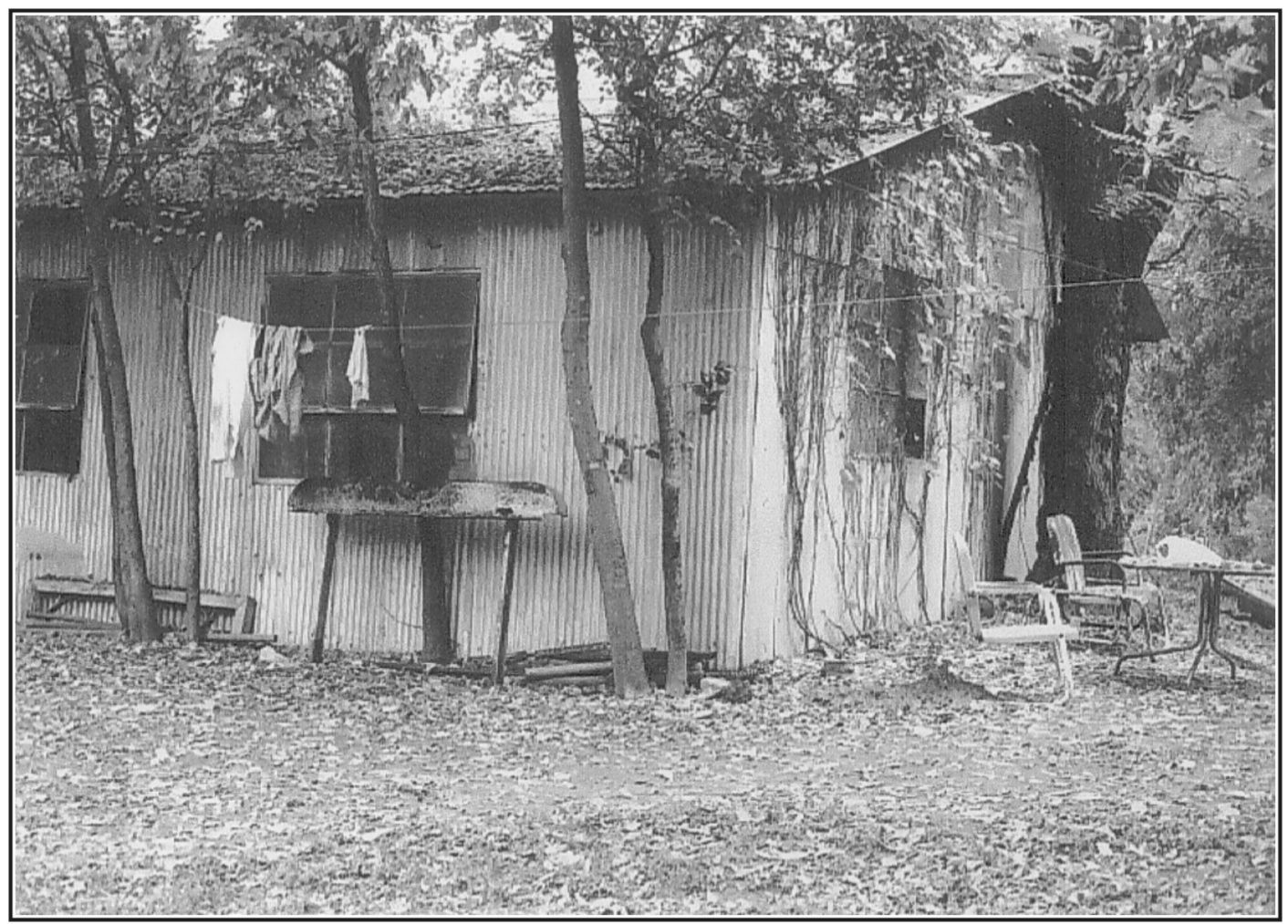

Figure 2-23. Historic Resource \#26 located on Avenue A (southeast façade). 
There is a dock area with a large overhead wooden door with visors. Currently, the property is used for storage but was used as a bookbinding facility in the past.

Historic Resource \#32 is located at 1126 E. Quincy Street and was constructed ca. 1945 (Figure 2-24). The property was owned by Julia M. Brogden until 1948 when she sold the property to D. R. Semmes (BCC 2006z). Currently, the building serves as an auto repair shop. There are four freestanding buildings arranged in an " $L$ " configuration on the property. Building \#1 is a two-story, rectangular brick building. The building has a metal frame, industrial windows (eight and 16 pane), wood doors and an elevated concrete slab foundation. Building \#2 is a single-story, rectangular metal building on an elevated concrete slab foundation used as a loading dock. It has a corrugated metal gable roof with overhangs. Building \#3 is a small, single-story, rectangular metal building with a corrugated metal gable roof. Building \#4 is a small, rectangular, metal-clad mobile office with a corrugated metal gable roof, metal doors, and windows.

Historic Resource \#33 is located at 221 Newell Avenue and was constructed ca. 1950 (Figure 2-25). It appears the property has been in the hands of the Samuel Glass
Company since the construction of the buildings. This historic resource consists of two primary buildings, both with multiple phases of construction. The main building is one story with a brick façade. The front portion has an art deco influence. There are numerous one-story clay tile blocks on the eastern portion of the buildings. The west building has three primary components. The southern portion is a metal building, with a metal roof and siding. The central portion is composed of structural clay tile with brick trim, industrial sash and a low slope roof. The eastern portion is composed of glazed metal.

Historic Resource \#35 is located at 212 Newell Avenue and was constructed ca. 1945 (Figure 2-26). Mitchell Motors, Inc. sold the property to Elwood Cluck in 1978 (BCC 2006aa). The Yellow Cab and Baggage Company purchased the property in May of 1948 from J. M. and Emma Harris. J. M. Harris contracted with G. W. Mitchell in April of 1940 to build a structure on the premises (BCC 2006bb). This historic resource is a single-story building composed of concrete block with a flat roof and concrete foundation. There are variety of window types, configurations and materials (steel, aluminum and wood). The building is currently used as an auto repair shop but was a taxicab company in the past.

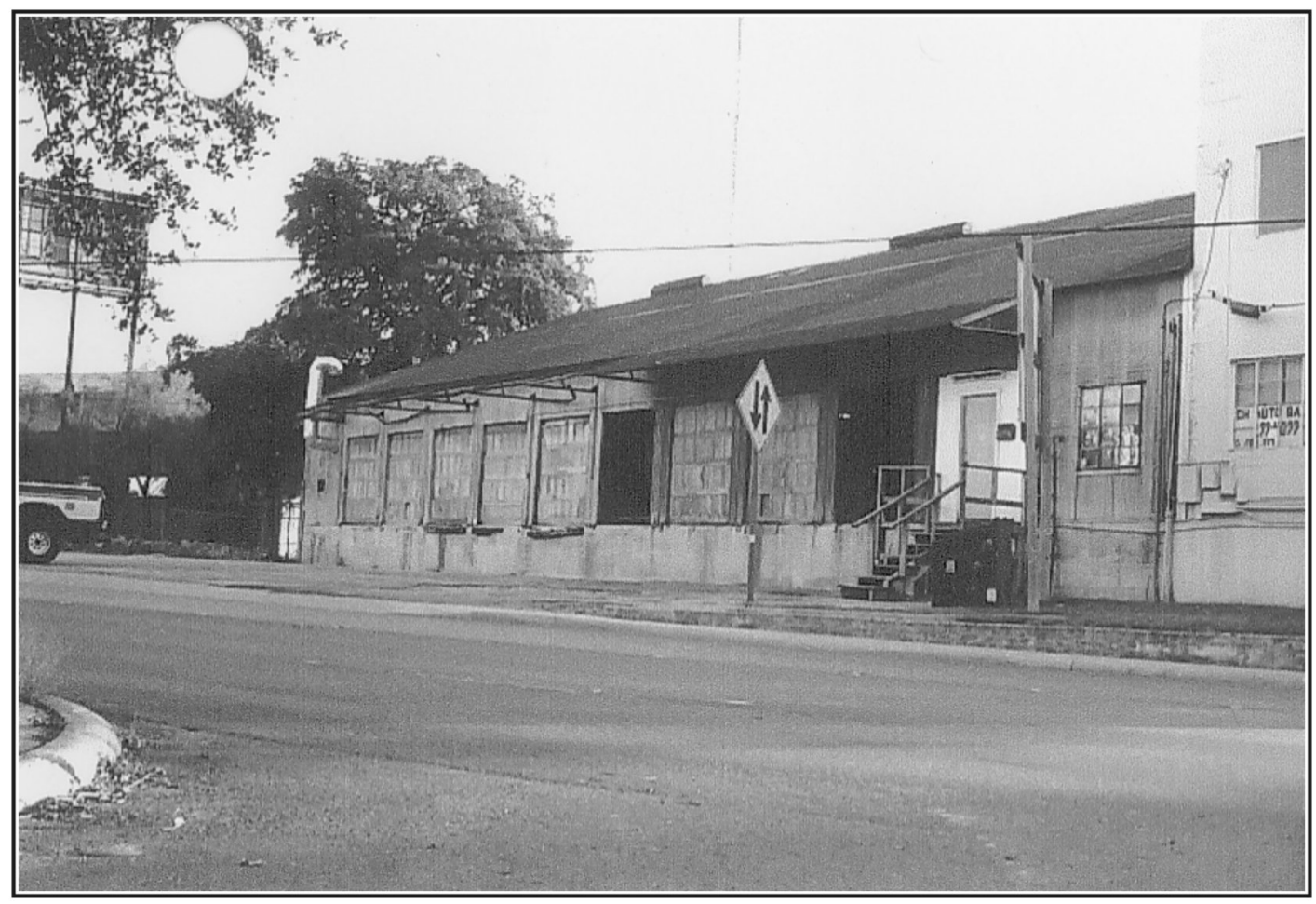

Figure 2-24. Historic Resource \#32 located on East Quincy Street (north façade). 


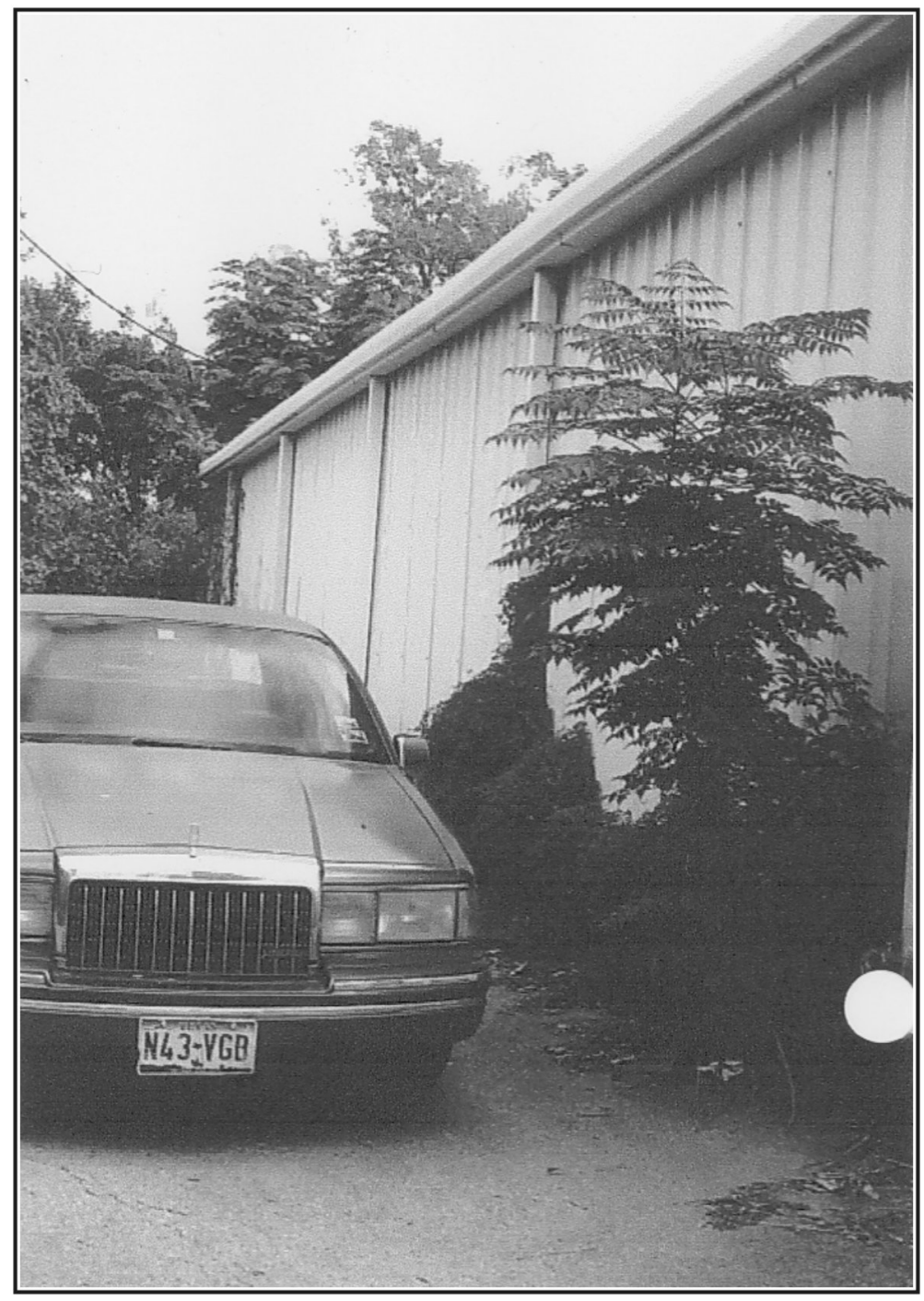

Figure 2-25. Historic Resource \#33 located on Newell Avenue (southwest façade).

Historic Resource \#37 (currently Elmira Motor Inn) is located at 1200 Elmira Street and was constructed ca. 1945 (Figure 2-27). The property was owned by Robert Lowe from 1938 to 1947 (BCC 2006cc; BCC 2006dd). This historic resource consists of four standing buildings arranged in a " $\mathrm{V}$ " that are currently used for motel purposes. Building \#1 is a two-story, rectangular brick veneer building with a low slope roof, boxed overhangs, and a concrete foundation. It has an out-set wooden porch, wooden doors, aluminum frame windows, exterior corridors and two exterior metal stairways.
Building \#2 is a single-story, rectangular brick veneer building with a low slope roof, boxed overhangs, and a concrete foundation. It has small, aluminum frame windows, wood doors, and an exterior corridor. Building \#3 is a single-story, rectangular, veneer brick building with a low slope roof, boxed overhangs and a concrete foundation. The southeast façade has wood doors, aluminum frame windows and an exterior corridor.

Building \#4 is a two-story, volume brick veneer structure that has a square plan. It has a low slope roof with boxed overhangs and a concrete foundation.

Historic Resource \#41, identified as an industrial property located at 102 Grayson Street, appears to have been built in 1950 (BCAD 2006). Bexar County Appraisal District states that a 7,200square-foot commercial garage service was constructed during that year. A 1953 plat shows that the property was owned by Foremost Dairies at that time. The Foremost Dairies purchased the property from R. L. White, J. H. White, Joella White Bitter, and Evelyn White Thomson in August of 1949 (BCC 2006ee). It appears that the building was constructed by Foremost Dairies during the early 1950 s.

Historic Resource \#42 is located at 100 Grayson Street and was constructed ca. 1945 (Figure $2-28$ ). The deed for this property was only traced back to 1994 when it was owned by William W. Atwell. Dead records prior to 1994 were not located. This historic resource is a two-story building that has a "T" plan configuration, described in three zones. At the north façade is a rectangular, single-story building with a metal low-pitch roof (Zone 1). Zone 2 is a half wood, two-story building with a slightly sloped roof of corrugated metal. The southern end (Zone 3 ) is a single-story block structure that forms the "T" of the building. The building is currently vacant.

Historic Resource \#45 is located at $102 \mathrm{~W}$. Josephine Street. Mainstreet Architects gave the building an estimated construction date of 1945, but according to the Bexar County Appraisal District records, construction in the form of a concrete block store and warehouse occurred in 1961. 


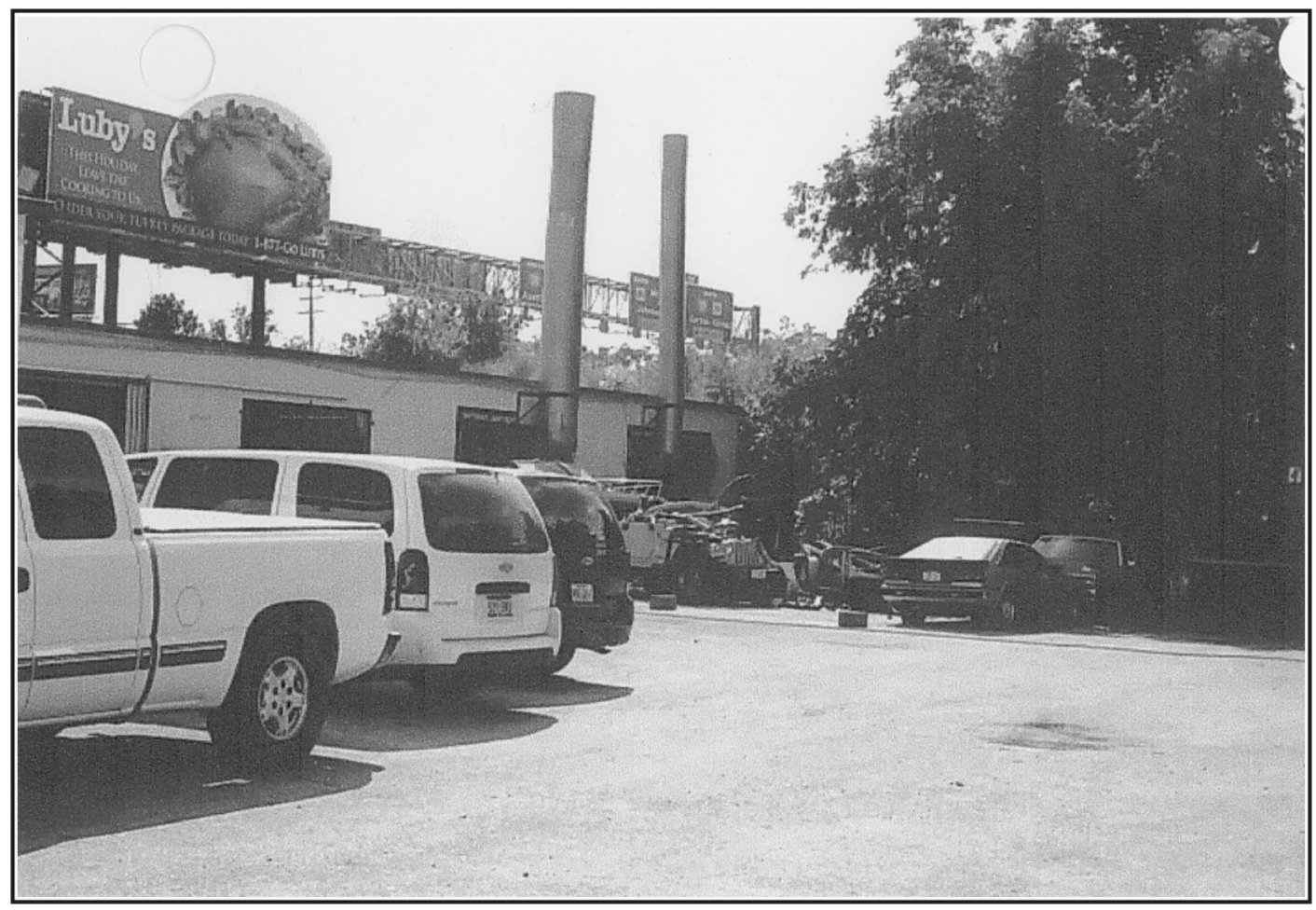

Figure 2-26. Historic Resource \#35 located on Newell Avenue (west façade).

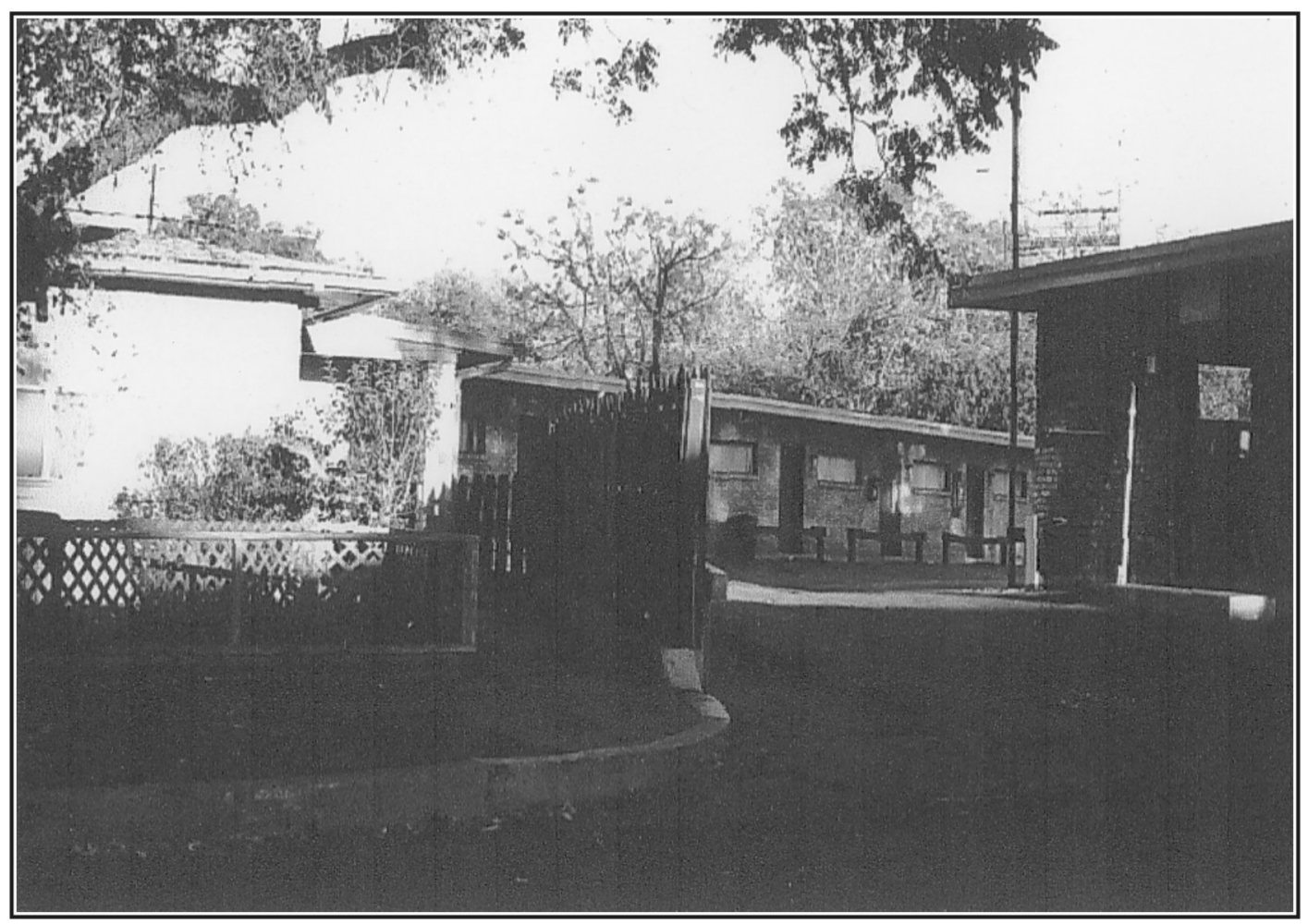

Figure 2-27. Historic Resource \#37 located on Elmira Street (view from the southeast). 


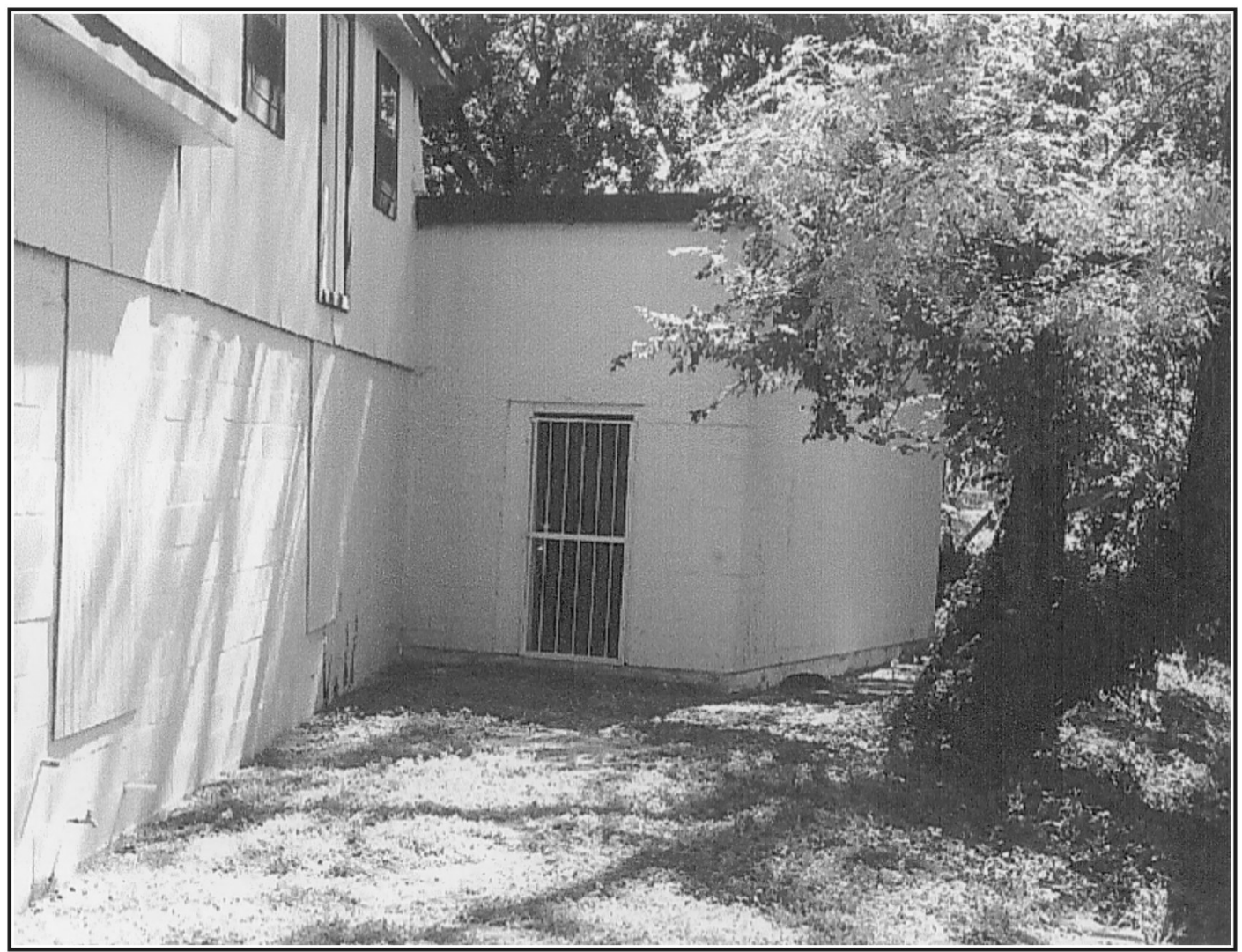

Figure 2-28. Historic Resource \#42 located on Grayson Street (west façade).

Though the building may have been constructed post-1955 according to Bexar County tax records, the property was owned by Frances G. and Sidney E. Cross in 1945 (BCC 2006ff). In 1946, Cross contracted William P. Lawless to construct a building on Lots 1 and 2 of the same block.

The property has three distinct building forms (storefront, house and warehouse) that are placed linearly. Building \#1 is a single-story, rectangular brick commercial storefront building with an asphalt shingle, hipped roof. It has red brick, aluminum-frame storefront windows. This is possibly the structure referred to in the Bexar County Appraisal District archives. Building \#2 is a two-story, rectangular plan that was originally a residential building. This structure was most likely built by Cross prior to 1945 . It has a floorlevel foundation with an asphalt shingle, hipped roof. The building has a stucco finish and wood-frame residential windows. Building \#3 is a single-story building with an elevated concrete slab foundation and a corrugated metal gable roof. The building has metal-frame windows facing the property's parking area.
Historic Resource \#46 (previously Taco Land) is located at 103 Grayson Street and was constructed ca. 1945 (Figure 2-29). The property was owned by Magnolia Petroleum Co. from 1933 to 1957; thereafter, the land was sold to W. F. Traxler (BCC 2006gg; BCC 2006hh). The property is a local historic landmark. It was home to "Taco Land," a live music hot spot in San Antonio. The owner, Ramiro Ayala, was shot to death in 2005 and the business shut down shortly thereafter. The property has three distinct building forms. Building \#1 is a single-story, rectangular brick building with an asphalt shingle roof. The southwest façade has a small pass-through opening and a metal door with a visor. Building \#2 is a brick building with a corrugated metal roof with a gable pop-up detail and stucco walls. Building \#3 is a taller, single-story, rectangular block building with an asphalt shingle, gable roof. On the west façade there is one wood passage door and one metal overhead door.

Historic Resource \#49, located at 120 Ninth Street, was identified as a single-story, square plan building with a metal roof. Bexar County Appraisal District indicates that a brick 


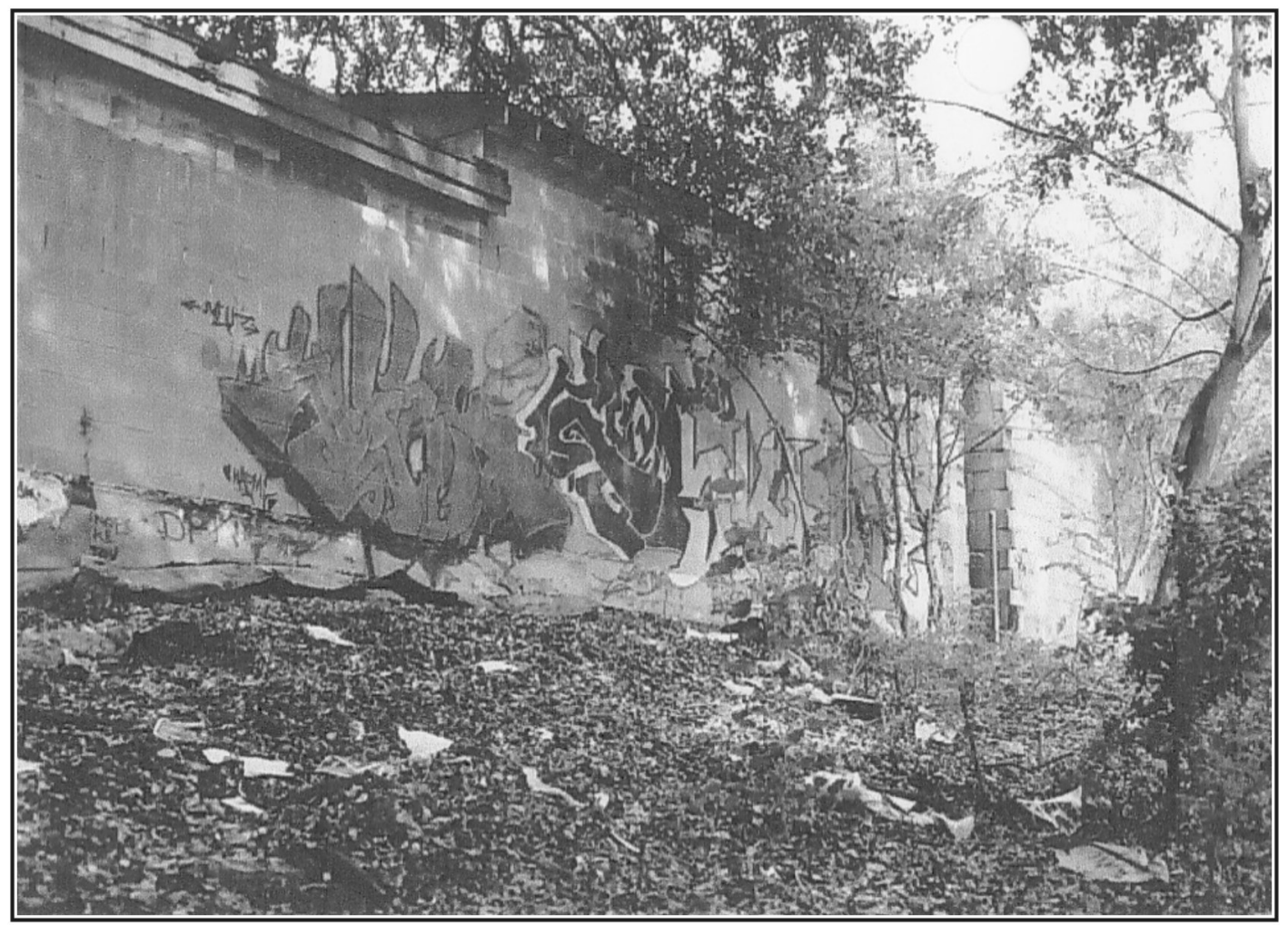

Figure 2-29. Historic Resource \#46 (Taco Land), east façade, located on Grayson Street.

clubhouse was constructed in 1965. The 1951 Sanborn map shows a building on the property, but no information of the building's purpose was recorded. Turner's, Inc. purchased the property in July of 1939 from Ernest Brown (BCC 2006ii). Turner's, Inc. has remained in possession of the property to this day, indicating that the structure was constructed by them and possibly utilized as an outbuilding.

Historic Resource \#50, located at 506 Brooklyn, is described as a single-story, three-bay, brick building. Bexar County records indicate that this was a restaurant constructed in 1938. A structure was noted on the 1924 Sanborn map at the same location. The City Directory indicates that a business under the name of Tom Jones Radio Shop was on the property during the late 1930s, though the address was listed differently. The property was conveyed to Billy Morton in March of 1968. The property was part of the estate of Emeline H. Pancoast and was sold to Morton so the beneficiaries could divide the proceeds (BCC 2006jj). It appears that the property remained in the Pancoast family from the early 1900s. It is possible that it was part of a larger portion owned by A. C. Pancoast and was passed to his wife, then the daughters. The building would have been built while the Pancoasts had ownership.

\section{Summary}

Of the 51 structures reviewed in the Historic Resources Inventory, 23 contained structures that predate 1955. The Inventory listed several more with possible construction dates occurring prior to 1955, but reviews of the Bexar County Deed Records and Bexar County Appraisal Records indicate that structures not previously discussed would have been constructed post 1955 .

There are several properties along the Museum "Urban" Reach corridor that are significant local landmarks in San Antonio. The Pearl Brewing Company (Historic Resource \#38) and the Lone Star Brewing Company (Historic Resource \#22) are renowned breweries in Texas history. Historic Resource \#13, located in the "Irish Flats" of San 
Antonio, is significant due to its location and historical use as the residence of the Lone Star Brewery brew master. Taco Land (Historic Resource \#46) is another significant San Antonio landmark. Though the construction period of several of the standing structures was estimated by architectural means, the historical use of a majority of the standing structures and properties is unknown. The historic structures that were once along the project area may have been removed to make way for newer structures. Many properties have been utilized since the late 1800 s, and possibly earlier by indigenous groups. 


\section{Chapter 3: Field and Laboratory Methods}

Although no known, previously recorded archaeological sites exist within the Museum "Urban" Reach portion of the project area, and channelization efforts may have destroyed all sites located in the immediate vicinity of the channel, significant archaeological sites may still exist within the floodplain of the San Antonio River. The Museum Reach project area was investigated using reconnaissance and intensive pedestrian survey methods in the form of backhoe trenches. Reconnaissance efforts were conducted along the ROW to inspect the project area prior to the intensive pedestrian survey. The goal of the intensive pedestrian survey was to locate all historic and prehistoric archaeological sites within the APE and to determine their size and the depth of their cultural material.

\section{Reconnaissance}

The main goals of the reconnaissance were to inspect the surface for cultural material, identify any potential areas not affected by channelization that would be appropriate for testing, and also search for an acequia outflow that would have been located along the eastern bank of the river behind the Pearl Brewery. During the reconnaissance, the western and eastern banks of the San Antonio River were explored by two teams, each made up of two individuals. Both teams utilized aerial photographs of the area for orientation. The goal of the reconnaissance was to locate appropriate areas for intensive archaeological pedestrian survey.

\section{Survey and Backhoe Trenching}

Based on the preliminary inspection of the geotechnical cores recovered along the project area by Arias \& Associates, Inc. and the inspection of the lower terrace during reconnaissance, shovel testing on the lower terrace would proceed through clay and would quickly reach waterlogged deposits given that this surface is only 4-6 ft. above the waterline. The colluvial slope that provides a transition between the lower and upper terraces is relatively steep, so no shovel testing was recommended along it, given the likely secondary depositional context of any materials found within the slope. This left the upper terrace, or portions of the riverbanks that have not been scoured through channel-widening, for subsurface investigations. Three such areas that contain sufficiently large segments of the upper terrace to allow for the search for buried deposits through backhoe trenching were identified during the reconnaissance. Given the degree of disturbance of the project area ROW, the limited areas where a deep profile still remains, and the absence of surface cultural materials observed during the reconnaissance, CAR proposed a significant alteration of the traditional shovel test-oriented survey methodology. Specifically, CAR proposed to eliminate the traditional pedestrian survey of the project area and focus archaeological and geoarchaeological efforts within the three areas identified above. In each of these areas, CAR proposed to limit subsurface investigations to $1-3$ backhoe trenches. The purpose of the trenches was to expose the subsurface deposits, allow geomorphological descriptions of soils and stratigraphy and also search for buried cultural deposits.

This method was recommended based on the assumption that archaeological deposits were buried more than 60-100 $\mathrm{cm}$ below surface (cmbs) in the floodplain of the San Antonio River, too deep for traditional shovel test methods to encounter. According to method guidelines, in the event that shallow archaeological deposits were revealed in a backhoe trench, shovel tests would be excavated to investigate the horizontal distribution of cultural materials. If cultural deposits were exposed in a backhoe trench deeper than $60 \mathrm{cmbs}$, auger boring was to be implemented to determine the extent of the subsurface deposits. In the case of deeper deposits, 9-in.-diameter auger bores were to be excavated to a maximum depth of $120 \mathrm{cmbs}$ in three, $40-\mathrm{cm}$ levels. If shovel tests were placed instead of auger boring, they were to be $35 \mathrm{~cm}$ in diameter and excavated in $10-\mathrm{cm}$ levels to a depth of $60 \mathrm{cmbs}$. All sediments would be screened through 1/4-in. mesh, all artifacts would be collected, and auger boring observations recorded on standardized forms. All backhoe trenches were recorded using a hand-held Trimble GeoExplorer II Global Positioning System (GPS) unit.

Backhoe trenches were excavated to a minimum depth of $1.5 \mathrm{~m}$ below surface and a maximum of $5.5 \mathrm{~m}$ or the depth of the water table. The backhoe trenches were $5 \mathrm{~m}$ in length and excavated perpendicular to the stream. Soil from the backhoe trenches was not screened, though notes on the stratigraphy and cultural features (if encountered) were recorded. At least a segment of one wall of each backhoe trench would be profiled unless the trench walls reflected a 
great degree of homogeneity, in which case only backhoe trenches reflecting different depositional processes and/or histories were to be documented. Soil column samples were extracted from selected trench walls to serve as a source for pollen presence/absence studies and magnetic soils susceptibility investigations.

\section{Laboratory Methods}

Only temporally diagnostic artifacts on the surface were to be collected and their location recorded with a GPS unit and on a sketch map. In case of artifact recovery, the specimens were to be washed, air dried and stored in 4-mm zip-locking bags at the CAR laboratory. Acid-free labels were to be placed in all artifact bags. Each label was to include provenience information and a corresponding lot number written in pencil or laser printed. Lithics and ceramics were to be labeled with permanent ink over a clear coat of acrylic and covered by a second acrylic coat. Artifacts were to be separated by class and stored in acidfree boxes identified with standard tags.

All project-related field notes, forms, photographs and drawings were placed in labeled archival folders. Photographs were labeled with archivally appropriate materials and placed in archival-quality sleeves. Inkjetproduced maps and illustrations also were placed in archival-quality page protectors. Sediment sub-samples from selected boreholes examined by the project geomorphologist, and all project-associated documents and records are permanently curated at the Center for Archaeological Research. 


\section{Chapter 4: Results of Reconnaissance Survey and Backhoe Trenching}

The reconnaissance portion of the fieldwork involved inspecting the ROW along the project corridor for potential shovel test and/or backhoe trench locations. Eight backhoe trenches were placed along the ROW of the project area. Boreholes were also drilled throughout the project area on both banks of the river. This chapter will discuss the results of the reconnaissance, backhoe trenching and auger boring. Backhoe trenching and auger boring in the APE have confirmed cultural resources may be preserved but historical channelization efforts have impacted the project area. Pollen analysis was conducted on samples obtained from backhoe trenches and boreholes (see Appendix C).

\section{Results of the Reconnaissance Survey of the Project Area}

On May 6, 2005, a reconnaissance was conducted along the Museum "Urban" Reach (Lexington to Josephine Streets) portion of the San Antonio River Improvements Project. The main goals of the reconnaissance were to inspect the surface for cultural material, identify any potential areas not affected by channelization that would be appropriate for testing, and also search for an acequia outflow that would have been located along the eastern bank of the river behind the Pearl Brewery.

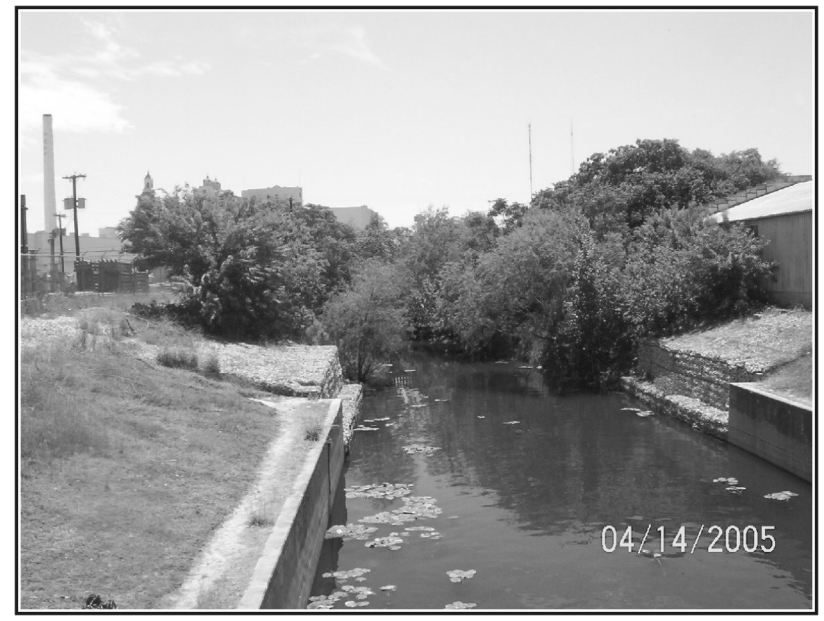

Figure 4-1. Concrete embankments near the northern end of project area, looking south from E. Josephine Street Bridge.
The dense vegetation and steepness of the channelized bank made reconnaissance efforts difficult. Unfortunately, the known location of the acequia outflow could not be closely inspected due to the narrowness and steepness of the bank in the portion of the APE abutting the Pearl Brewing Company fence line, and the fact that a large sewer outflow was located in the immediate vicinity.

Portions of the project ROW have been heavily impacted by modern alterations of the banks of the river including concrete embankments (Figure 4-1), bridge construction (Figure 4-2), and landscape-related sculpting (Figure 4-3). The reconnaissance indicated that there are two river channel profiles predominate within the project area. The most common channel profile is characterized by narrow stretches of high banks just inside of the project ROW dropping rapidly and steeply to lower terraces sitting 4-6 $\mathrm{ft}$. above water level immediately adjacent the active channel of the river (Figure 4-4). While the active, water-carrying channel is usually $8-10 \mathrm{ft}$. in width, the adjacent, lower terrace varies from $5-15 \mathrm{ft}$. on each bank of the stream. The higher, upper terrace sits $8-10 \mathrm{ft}$. above the lower terrace and only in a few places is it more than 3-6 ft. wide along the project ROW.

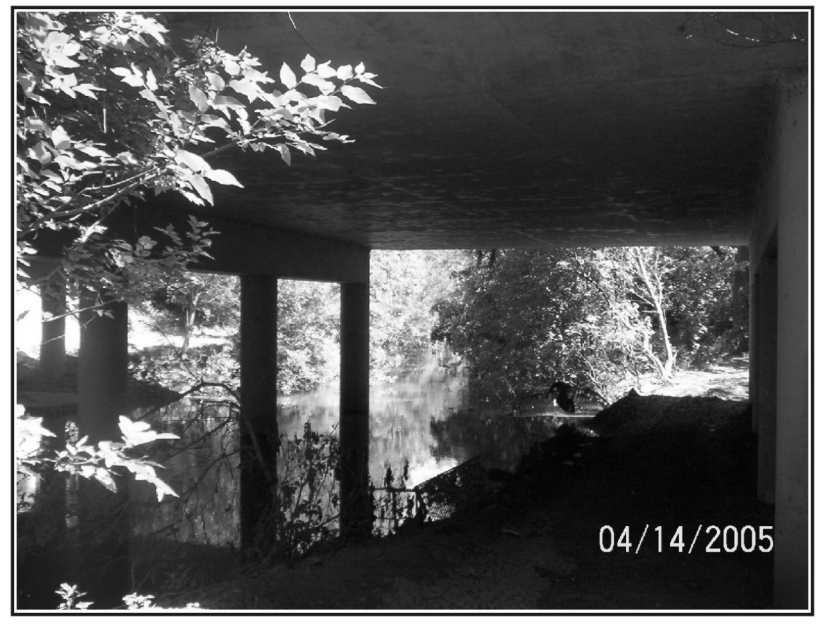

Figure 4-2. West bank of San Antonio River under the Newell Street Bridge. 


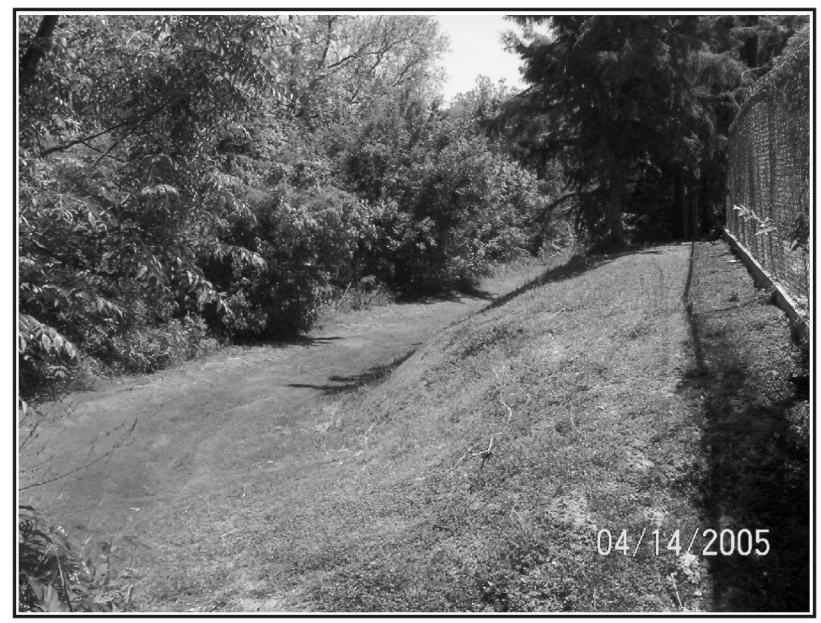

Figure 4-3. Cleared portion of west bank of the San Antonio River near the IH-35 overpass.

In portions of the San Antonio River, this profile is the result of channelization; however, the profile is also found in portions of the river that have not been channelized according to available records. In these areas, the profile results from systematic widening of the channel rather than its reorientation through channelization. The channel of the river appears to have been widened in many places where channelization did not eliminate meanders in order to allow greater flood capacity without floodwaters exiting the channel proper. The upper terrace represents the original ground surface of the floodplain. The lower terrace merges into the upper terrace as a relatively steep colluvial slope.

The second channel profile is found in only a limited number of areas and consists of steep banks that drop immediately to the edge of the water in the active stream channel. In these instances a lower terrace is not present adjacent the active channel but instead the stream flows immediately up to and against the bank. The top of the bank represents the ground surface of the San Antonio River floodplain. This bank morphology may be the result of active bank undercutting by the river.

The reconnaissance of the APE conducted by CAR personnel did not identify any surface archaeological deposits along the ROW. The low terrace sits only about 4-7 ft. above the waterline and is covered with dense secondary growth; the deposits that may have had cultural materials were removed either through channelization or the widening of the active channel. The upper terrace that is $10-17 \mathrm{ft}$. above the waterline is the original floodplain surface but it is present within the project ROW only as

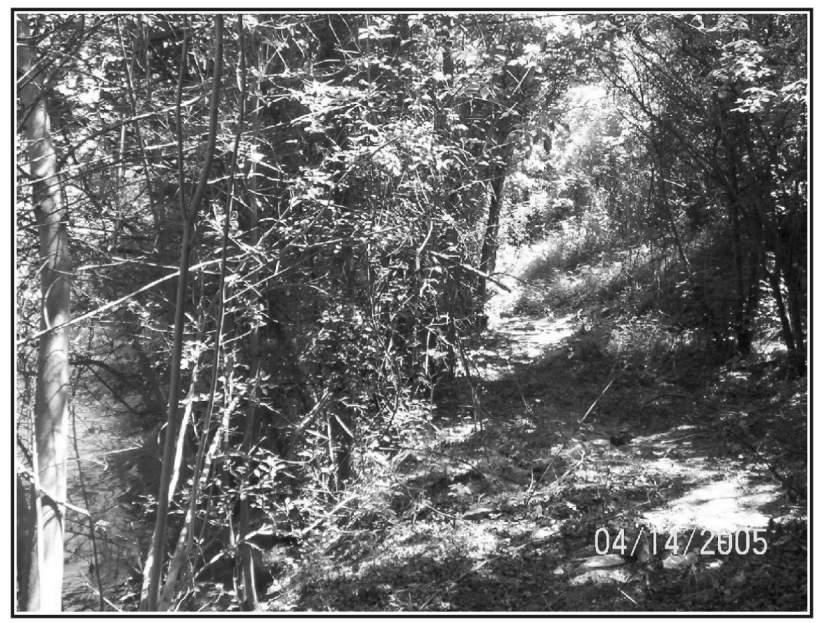

Figure 4-4. Lower terrace immediately adjacent to active channel of the San Antonio River.

narrow strips rising from the lower terrace and abutting property fence lines. Archaeological deposits were not noted on the slope connecting the two terraces.

Three areas that retain portions of the upper terrace sufficiently wide enough to allow subsurface inspection for buried archaeological deposits were identified during the reconnaissance. The northernmost of these locations is on the west-descending bank of the river between East Myrtle Street and Newell Avenue just east of Schiller Street (Figure 4-5). It is immediately across from an acequia outflow and current location of a sewer main that crossed under the Pearl Brewery. The locality is immediately south of one of the meanders that was cut through by channelization efforts. The second location, also on the west-descending bank, begins immediately south of West Jones Avenue and is immediately north of a section that was straightened through channelization (Figure 4-6). The third location where a section of the upper terrace of the San Antonio River is preserved and accessible for subsurface investigations is located immediately north of Ninth Street on the westdescending bank (Figure 4-7). This section is in a channelized portion of the river, well away from the original channel that flowed west of its current location.

Short and narrow segments of the upper terrace are preserved in other portions of the project area; however, these segments are not accessible from street level, rather, one would have to access them from the lower terrace of the river and in most instances the insertion of heavy equipment would be difficult and dangerous, if at all possible. 


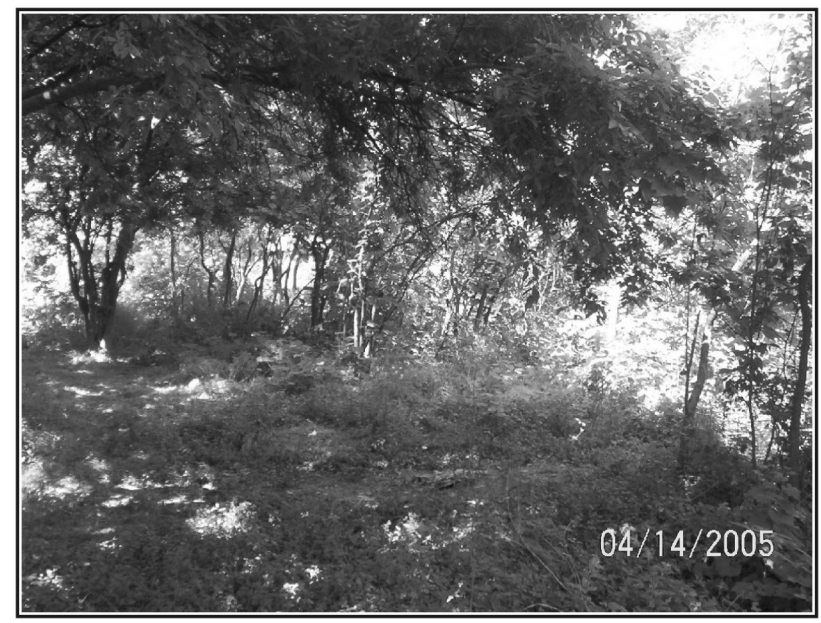

Figure 4-5. Northern segment of the upper terrace available for backhoe trenching along project area just east of Schiller Street.

The entire project ROW was inspected in search of additional areas that may have geomorphological potential or intact floodplain deposits. No such areas, besides the three identified during the initial reconnaissance were noted. The following section describes the results of the geomorphological work conducted by geomorphologist Christopher Caran and CAR staff member Charles Speer.

\section{Geoarchaeology of the Proposed San Antonio River Improvements Project, Museum Reach}

\section{S. Christopher Caran and Charles A. Speer}

\section{Introduction and Geomorphic Setting}

The Museum Reach project area is part of the upper San Antonio River basin in the West Gulf Coastal Plain physiographic region (Fenneman 1946; Geological Survey 1992). Intermittent streams drain into the upper San Antonio River from its surficial watershed in part of northern Bexar County (Geological Survey 1985, 1992). The upper San Antonio River itself is perennial, primarily conveying discharge from San Antonio Springs, located $2.6 \mathrm{~km}$ northeast of the Museum Reach (Brune 1975:32-33, 1981:70-72; Geological Survey 1992). Flow from San Pedro Springs (now essentially inactive) formerly entered the San Antonio River farther downstream, through San Pedro Creek.

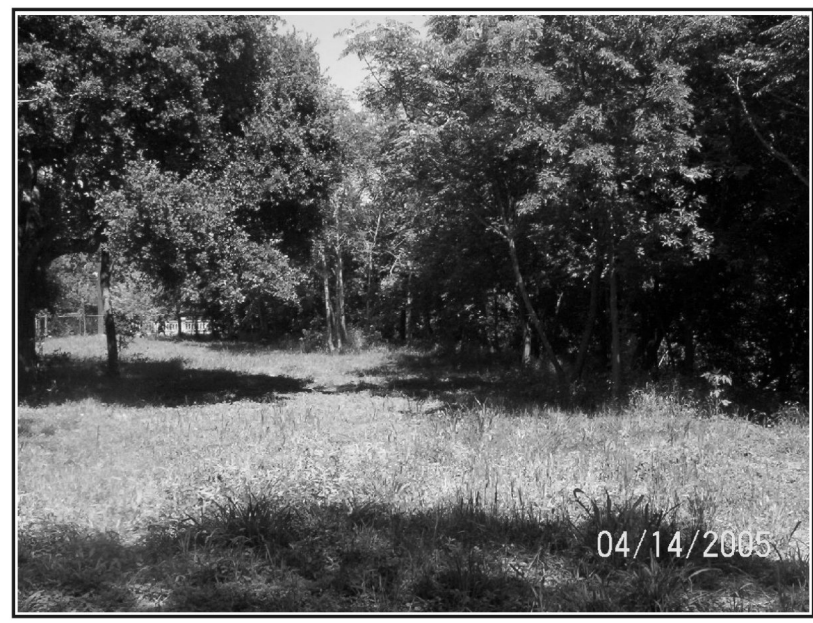

Figure 4-6. Segment of upper terrace available for backhoe trenching just south of $W$. Jones Avenue Bridge.

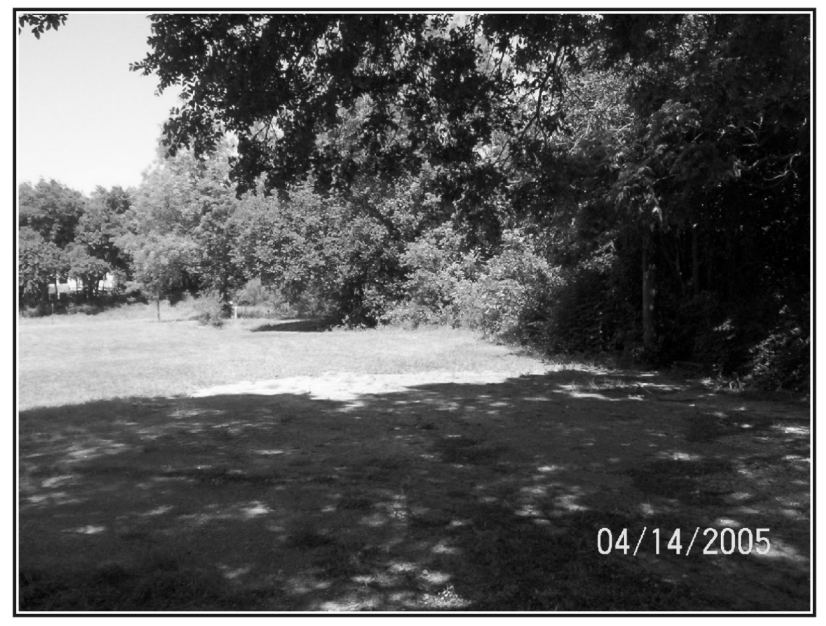

Figure 4-7. Southern segment of upper terrace on west bank of river, just north of Ninth Street Bridge.

Exploitation of these water resources began during the Spanish Colonial Period. Water was diverted from both the river and San Pedro Creek for irrigation beginning in 1719, and continues to be taken from the river even today (Cox 2005:17-22). Flow was sufficient to also power a series of grain mills from 1730 to the mid-1900s and hydroelectric power generators beginning in the 1900s (Brune 1975:33). From the early nineteenth century to the present, ground water withdrawal from numerous wells has greatly reduced the spring volume, such that flow must now be supplemented to maintain the river (Brune 1981:71-72). In addition, the river channel has been modified repeatedly by partial realignment and dam construction for the 
previously mentioned purposes, flood control, and scenic value, and filling and bank stabilization for agriculture and urbanization (Brune 1975:33; Cox 2005:25-27). The channel within the Museum Reach was extensively, but not completely, rectified in the aftermath of a devastating flood in 1921 (highest water level since at least 1819) and to enhance urban beautification beginning in 1939 (Donecker 1996:811; Patterson 1965:298).

Geomorphic and related characteristics of the Museum Reach in the prehistoric past can be reconstructed from early historical accounts and stratigraphic evidence (see Stratigraphic Profiles, below). The river was far different from the slow, narrow, modestly meandering, and relatively deeply inset, yet shallow stream of today. In 1716, Father Espinosa reported that

...we arrived at the River San Antonio. This river is very desirable and favorable for its pleasantness, location, abundance of water, and multitude of fish. It is surrounded by [a heavy growth and wide variety of woody and herbaceous plants, including mesic and aquatic species]. Merely in that part of the density of its grove which we penetrated, seven streams of water meet. Those, together with others concealed by the brushwood, form at a little distance its copious waters, which are clear, crystal and sweet. In these are found catfish,...[other fish],... and alligators [Tous 1930:3, 5].

George W. Bonnell (1964[1840]:96) provided another early description:

The San Antonio river is formed by about one hundred large springs in a beautiful valley... Many of these springs would singly form a river; and when they unite in the San Antonio, they form a bold and rapid stream of two hundred feet in width, and about four feet deep over the shoals. The river has considerable fall, and the early settlers have taken advantage of it for irrigation, and by means of ditches, the water of the river has been carried over the whole valley of the San Antonio. The fertility, beauty, and healthiness of this valley have been celebrated from its earliest settlement.

Yet other observations were offered by Frederick Law Olmsted (1982[1857]:156-157):
The San Antonio Spring may be classed as of the first water among the gems of the natural world. The whole river gushes up in one sparkling burst from the earth. It has all the beautiful accompaniments of a smaller spring, moss, pebbles, seclusion, sparkling sunbeams, and dense overhanging luxuriant foliage. The effect is overpowering... The temperature of the river is of just that agreeable elevation that makes you loth to leave a bath, and the color is the ideal blue... It remains throughout the year without perceptible change of temperature, and never varies in height or volume.

These statements foster a number of conclusions regarding prehistoric conditions along the upper San Antonio River. Ground water reportedly discharged from numerous springs in close proximity, with a combined flow that was both enormous and relatively stable. The source of the springs had to be an aquifer so vast that it transmitted large volumes of ground water and was well insulated from the effects of local, seasonally variable rainfall events that might otherwise cause wide fluctuations in flow rates. The commentaries further indicate that the water temperature was constant and comfortable. This confirms that the aquifer was large enough to retain infiltrated rainwater through one or more full years, allowing it to reach equilibrium with the mean annual air temperature of $20.6^{\circ} \mathrm{C}$ at San Antonio (Griffiths and Bryan 1987:49). In addition, both the springs and river were said to be clear to bluish in tint and the water was not merely potable but pleasing to taste. The high diversity of plant and animal life further corroborates the reputed excellent water quality. These are characteristics of ground water discharged from a porous limestone aquifer at a high rate of flow. In fact, San Antonio Springs have long been known to emerge from the karstic Edwards limestone aquifer, which was under tremendous artesian pressure until well withdrawals became excessive during the past century (Hill and Vaughn 1898).

Before merging into the river, the spring waters apparently flowed into short, spring-run streams draining through a heavily vegetated marshy area bordered by riparian woodlands. These observations indicate that the head of the San Antonio River was a wide cienega or ground water sustained marsh in which shallow, spring-fed streams meandered, diverged, and rejoined (cf. Bates and Jackson 1980:112). Marshy conditions may have extended several kilometers downstream. The river probably had a braided 
channel comprising a number of distributaries, uniting into a broadly meandering channel with a wide floodplain beyond. This conception of the river is different from that held traditionally, but appears to be consistent with historical accounts. Drainage modifications and water utilization from the early eighteenth century to the present have served to stabilize the channel network, creating the single, gently meandering, moderately entrenched river channel of today. We may test the hypothesized model of a more complex channel system in the past when examining the stratigraphic evidence.

Flow conditions at the river's headwaters were comparatively stable, maintained year-round by spring discharge. Beginning just a short distance downstream, however, runoff from heavy seasonal and episodic rains caused flooding of moderate to severe intensity (Patterson 1965:298). South-central Texas is one of the most floodprone areas in the United States (Caran and Baker 1986; Slade and Patton 2003). Floods are capable of transporting very coarse bedload, but most remains within the deepest parts of the river channel where flow is fastest. Coarse sediment is thus confined during all but the most extreme floods, even when floodwaters extend across the entire floodplain. Outside of the channel, floods normally carry sediment only in suspension. The suspended sediment consists of low-density organic matter and clay- to silt-size particles of inorganic minerals. Suspended sediment is easily transported. Large quantities are conveyed out of the channel and onto the floodplain, or are simply redistributed within the floodplain itself. This sediment is then deposited as the waters recede, particularly if the floodplain is wide, such that flow velocity dissipates quickly.

The process of fluvial sedimentation (deposition by rivers and streams) has important implications for culturalresource management. Archaeological sites on floodplains often remain undisturbed by floods. Flow velocity declines dramatically when the water overtops the banks and spreads laterally. Slow flowing water cannot entrain dense materials such as hearthstones and lithic artifacts, but can carry finegrained, organic-rich sediment. When flow velocity drops too low, this sediment falls out of suspension. The resulting overbank deposition is sufficient to bury sites quickly and perhaps deeply. Conversely, if no flooding had occurred, or if all or most of the deposits were Pleistocene in age or older, the likelihood of discovery of prehistoric cultural resources at depths greater than a few tens of centimeters would be very small. The importance of an accurate geoarchaeological model of the landscape is clear.
The principal published geological map of the San Antonio River Improvements Project (SARIP) area identifies the deposits within and immediately adjacent the San Antonio River as Holocene "low terrace deposits above flood level" (Brown et al. 1983). This indicates that the terrace is thought to be an inactive relict landform on which there would be little potential for burial and preservation of cultural resources. Based on data collected during the present investigation, this interpretation is erroneous. Through most of the Museum Reach, the river need rise only 3 to $4 \mathrm{~m}$ to overtop its bank (Bacon 2005; Geological Survey 1992). Stages of this and greater magnitudes have been recorded several times since gaging began in 1915 at a site $2.4 \mathrm{~km}$ southwest (Patterson 1965:298; Slade and Patton 2003). Major floods of the historical past are often good indicators of flooding potential during prehistory. Thus, for at least the past several thousand years, the "low terrace" may have received significant overbank sediment. The published soil survey of Bexar County supports this conclusion. Taylor and others (1962:32, Map Sheet 54) mapped the soils of most of the SARIP area as the "Trinity and Frio soils, frequently flooded." The presence of Holocene flood deposits denotes a potential for archaeological site preservation.

Historical channel rectification, emplacement of artificial fill, and diminished mean flow (as a result of reduced spring discharge) have changed the nature of the upper San Antonio River valley dramatically. Classifying the present broad landforms adjacent the riverbanks as floodplains is, therefore, inappropriate. Instead, these landforms do have the morphologic expression of low terraces - proximity to the river, relatively flat topography, and limited, yet pronounced vertical separation from the channel - as noted by Brown and others (1983). In contrast to Brown and others (1983), however, the history of flood inundation, even in recent years, and the associated potential for Holocene deposition demonstrate that these terraces should be referred to as "flood terraces," a term coined by Caran and Mandel (1988). This terminology is adopted here, but with some qualification because the current vertical separation from the channel is largely attributable to artificially enhanced channel entrenchment and widespread filling to raise the ground level. Despite clear evidence of artificial filling, a preliminary assessment of the project area indicated that Holocene deposition within the project area was almost certainly more extensive than the available geological mapping suggested, and may have effected at least moderate site burial. The cultural-resource potential of the project area was, therefore, tested directly, through examination of 
stratigraphic profiles in eight backhoe trenches and 17 boreholes drilled previously for geotechnical investigations.

\section{Stratigraphic Profiles}

The present investigators examined stratigraphic profiles at three locations, in a total of eight backhoe trenches (Figure $4-8$ ). Seven of the trenches exposed as much as $2.6 \mathrm{~m}$ of historical and modern fill materials, but no natural deposits. Pre-modern, non-anthropogenic strata were found in only one trench, beneath $65 \mathrm{~cm}$ of fill. S. C. Caran described the local geomorphic setting and stratigraphy of each trench profile and collected a limited number of sediment samples for laboratory analyses. C. A. Speer recovered and identified a number of historical and modern artifacts and collected selected items for further study and use in the teaching collection at the Center for Archaeological Research. All profiles and their landscape contexts were photographed.

Encountering extensive deposits of artificial fill was merely one of the challenges associated with trenching in the urban environment of San Antonio. It was also necessary to avoid paved surfaces, underground utilities, and existing structures. In addition, the proposed construction corridor is extremely narrow, impeding backhoe access in some areas, particularly in the southern part of the Museum Reach. The eight backhoe trenches were excavated in the only locations considered suitable, but they failed to provide complete coverage of the project area. Safety issues and other considerations limited the maximum depth of the trenches to less than $3 \mathrm{~m}$; whereas the thickness of Holocene deposits along the nearby Medina and other rivers in the region may exceed $10 \mathrm{~m}$ (Thoms and Mandel 2006). The chronology and genetic history of deposits within the upper San Antonio River valley were virtually unknown prior to the current study.

For these reasons, the present investigators sought a more robust data set. Arias and Associates, Inc., a geotechnical engineering firm in San Antonio, had drilled numerous deep boreholes throughout the project area to obtain core samples for foundation testing. The borehole records and any surviving samples were requested from Arias, in order to determine if they might provide stratigraphic data for the current geoarchaeological assessment. Moreover, the data were from more locations and greater depths than those accessible by trenching. Arias staff readily offered all relevant drilling information and those core samples not destroyed during testing. S. C. Caran described the existing samples from the most complete core sequences and collected subsamples from three of them. Results of the examination of the backhoe trench profiles and cores and of the analyses of samples from both the trenches and boreholes are discussed below. Radiocarbon/carbon stableisotope and palynological analyses of the samples are also presented as Appendices B and C, respectively.

\section{Backhoe Trenches}

As noted previously, a total of eight backhoe trenches (BHT1 through BHT8) was excavated at three locations on the right (northwestern) bank flood terrace of the San Antonio River:

1. Jones Avenue locality: A large tract containing one or more former residences, now cleared, located immediately southwest of the northwestern end of the Jones Avenue bridge over the river (BHT1-2);

2. Schiller Street locality: Several cleared and/or undeveloped lots southeast and east of the corner of Schiller Street and East Quincy Street (BHT3-4) and southwest of the southeastern end of East Myrtle Street (BHT5); and

3. Ninth Street locality: A long, narrow, partly cleared strip within the grounds of a former home site immediately northeast of the northwestern end of the Ninth Street bridge over the river (BHT6-8).

Observations at these trenches are summarized in Table A-1 (Appendix A). Seven of the trenches (BHT1-7) exposed historical and modern fill throughout their profiles, to depths greater than $2.6 \mathrm{~m}$. One trench, BHT8, similarly unearthed a layer of historical to modern fill material, but reached natural deposits, as well (Table A-2; Figures 4-9 and 4-10). Sediment samples were collected from this profile for radiocarbon/carbon stable-isotope (three samples) and palynological (five samples) analyses.

\section{Boreholes}

Arias and Associates, Inc. drilled 63 boreholes (B-1 through B-30 and B-32 through B-64) throughout the Museum Reach, on both the right and left banks of the San Antonio River (Bacon 2005). In general, the boreholes were numbered from north to south, i.e., downstream. Maximum 


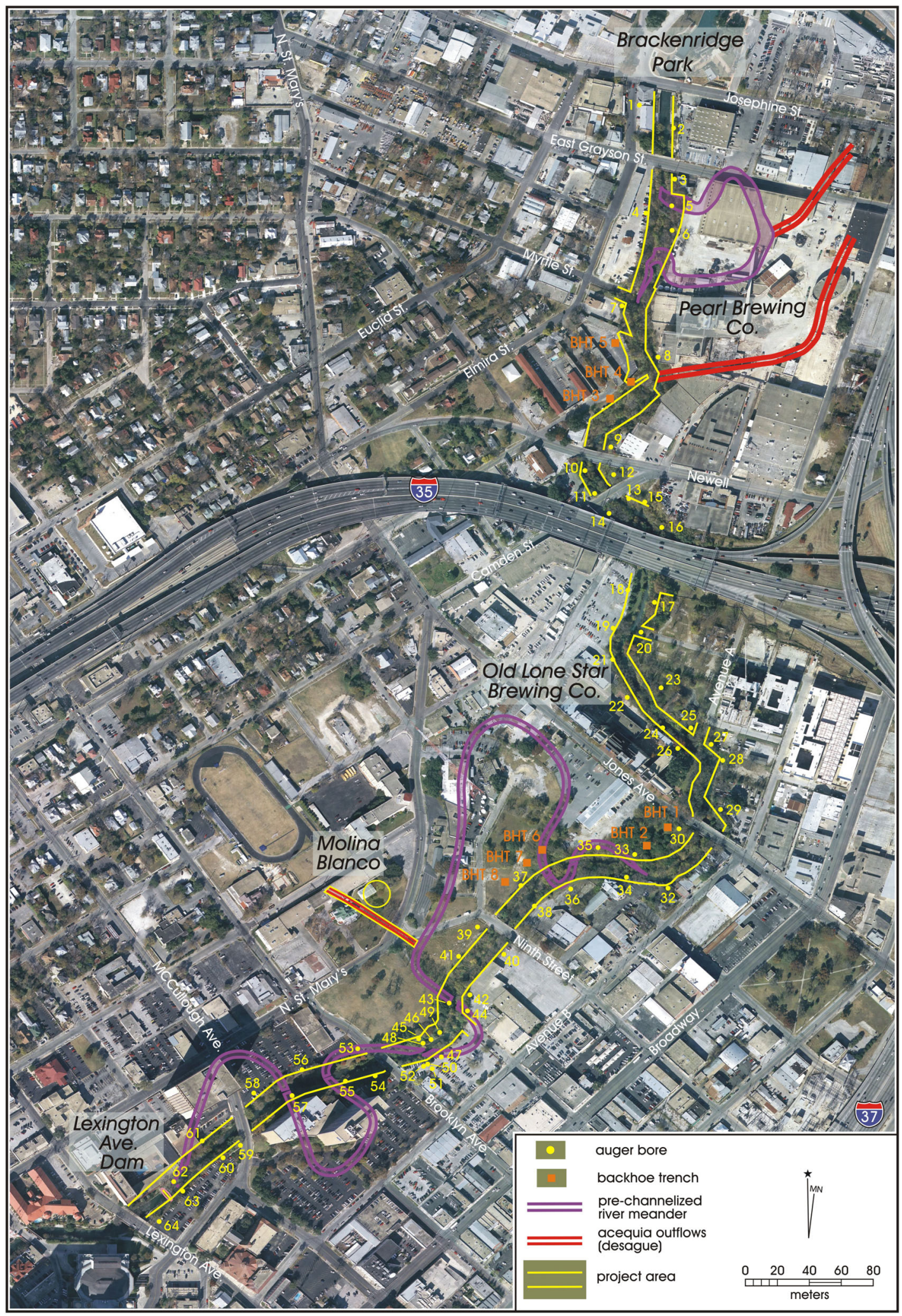

Figure 4-8. Locations of backhoe trenches and auger bores in the project area. 


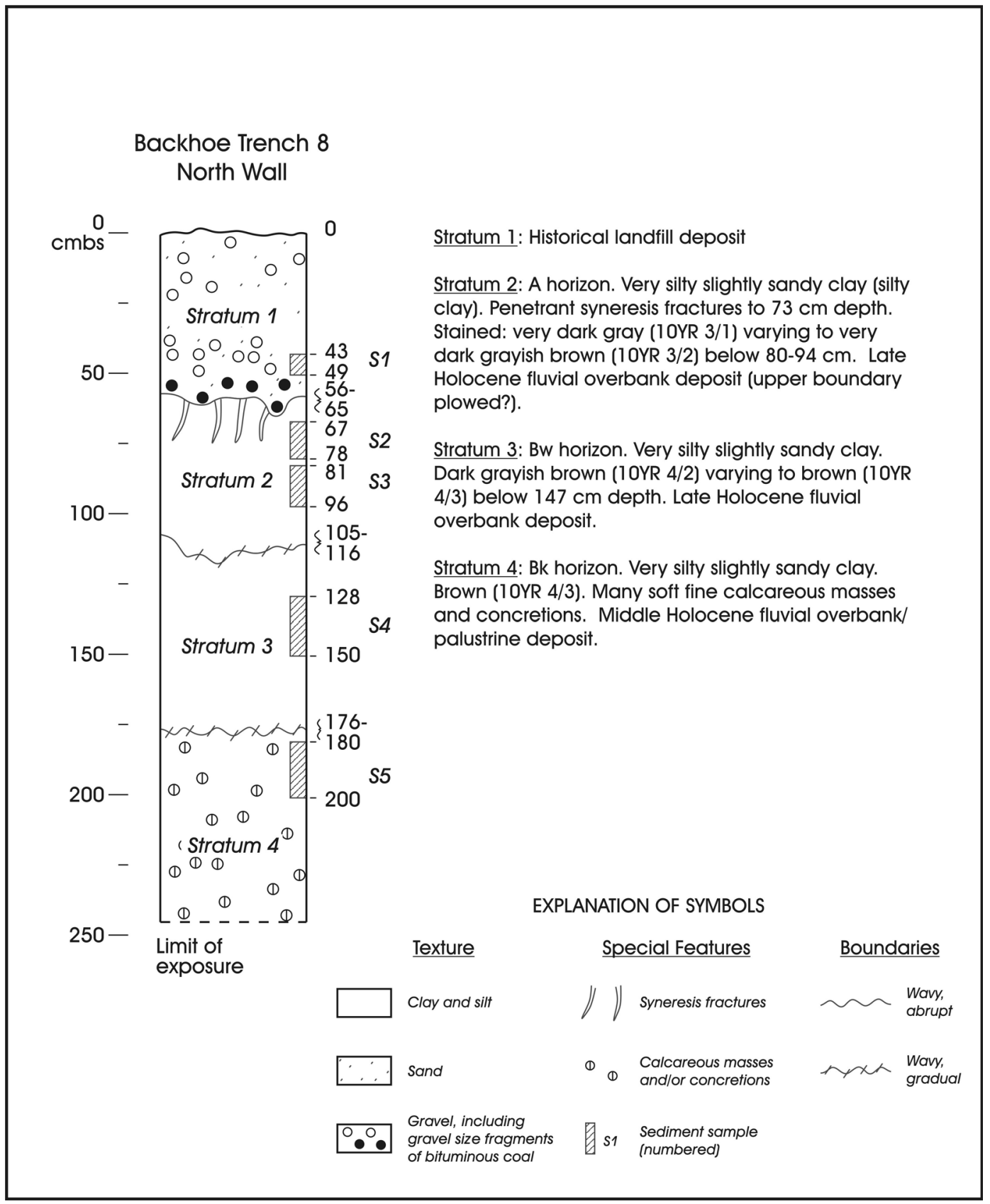

Figure 4-9. Stratigraphic profile exposed in northern wall of Backhoe Trench 8 (see Tables A-1, A-2, and $B-1)$. 


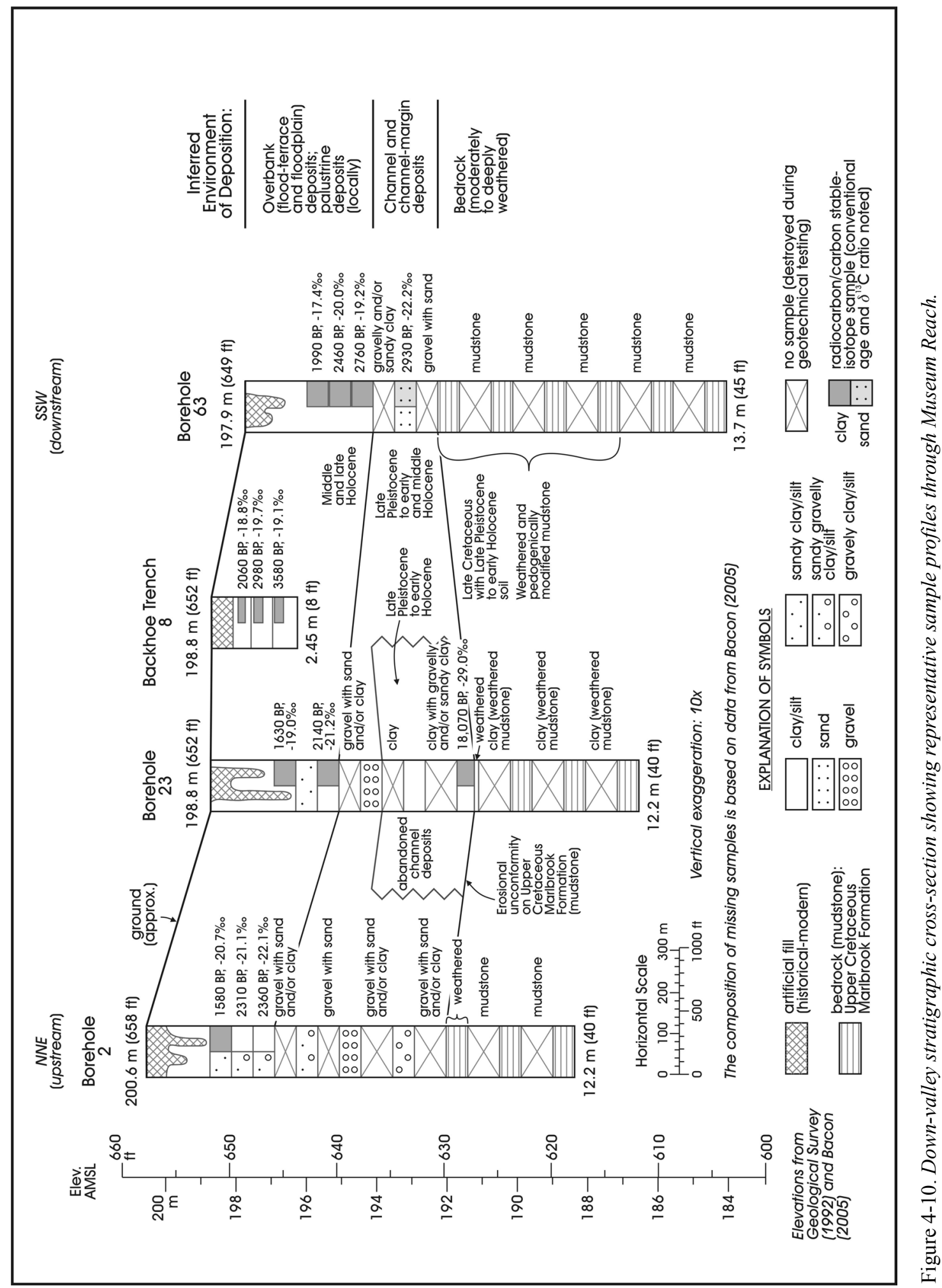


depth of drill penetration was $21.3 \mathrm{~m}$ (B-46), well beyond the range of backhoe trenching. The boreholes therefore provided data regarding deposits that were otherwise inaccessible. By the time the present geoarchaeological investigation began, however, many of the core samples were missing, having been subjected to destructive geotechnical testing. None of the core sequences were fully intact and those fragments that had been preserved were often small and disaggregated. In addition, earthen fill and historical debris were present at each of the borehole locations, in thicknesses varying from approximately 0.6 to $3 \mathrm{~m}$. Evidently, thick fill covers all or much of the flood terrace within the Museum Reach, on both banks. Despite these limitations, Caran was able to describe the residual samples from 17 of the boreholes and collected subsamples from three of them: B-2, B-23, and B-63 (Table B-1, Appendix B). Ten radiocarbon and carbon stable-isotope analyses were obtained from these cores. Stratigraphic records at most of the 17 boreholes chosen for this study were relatively complete and inferences regarding the genetic stratigraphy and age of the strata are reasonable. The availability of borehole samples and drilling data greatly enhanced the findings of the present investigation, providing information that, while imperfect, is to date the most comprehensive synthesis of the Quaternary history of the San Antonio River.

\section{Observations and Interpretations}

The following observations and interpretations are based on the results of the field and laboratory findings of project personnel and the results of geotechnical drilling and testing by the staff of Arias and Associates, Inc. (Bacon 2005).

\section{Historical Fill and Topographic Features}

The presence of fill deposits in all eight backhoe trenches and 17 boreholes discussed here is telling. Both the river and adjacent lands within the Museum Reach have been modified extensively since the advent of local European settlement, probably in 1719 (Cox 2005:18). The fill represents deliberate and incidental wastes from household, municipal, and industrial/commercial sources; earth materials from acequia construction, agriculture, channel rectification, bank stabilization, and flood protection; structural foundations and roadways; anthropogenic debris dispersed by flood waters; and other substances. Based on the associated artifacts recovered during the present investigation, none of the fill examined was older than the late 1800s (Table A-1). Older historical deposits and artifacts have, however, been found at a number of sites nearby (Fisher 1996).

One goal of the investigations was to discover evidence of Spanish acequias, first excavated in the early 1700 s to provide communal water supplies (Cox 2005; Frkuska 1981). Maps of the acequias and later water-management systems along the San Antonio River demonstrate that the Museum Reach and flood terrace were continually reshaped throughout the city's history (Figure 4-8; Cox 2005:19, 21, 26). Small dams were built at several locations along the river and major streams, partly obstructing flow and raising the water levels. Water was then easily diverted into the excavated acequias and conveyed through ever-smaller canals until reaching individual fields and habitation sites. The overall slope of the flood terrace parallels that of the river channel: approximately $0.4 \%$ (Geological Survey 1992). This gentle downstream gradient produced a manageably slow rate of flow through the canals, but was sufficient to allow irrigation water to be dispersed across most of the valley floor, extending far beyond the Museum Reach.

The original alignment of the acequias corresponded to the natural topography and locations of arable lands within the valley. Once established, however, this essential water infrastructure defined or controlled property boundaries, roadways, and later, utilities. Even today, "the enduring impress of Spanish design on the American city" is clearly evident upon examination of any local street map (Cox 2005:viii). Roads outside of the valley floor primarily form a rectilinear grid corresponding to the cardinal directions. In contrast, the bottomlands are marked by a complex network of streets with orientations mirroring the former flow diversions, tailwater returns, and distributary ditches, which typically bifurcated in the downstream direction (Figure 4-11). For example, see the mostly unnamed roads between Josephine Street and Lexington Avenue on the right bank on the river in Figure 4-11. Although we were aware of the locations of some acequias and suspected others based on the road pattern, we were unable to find any direct evidence of them. The thickness of the historical fill prevented exposure of the natural landform and underlying deposits in all but one backhoe trench. In addition, repeated modification of the river channel has undoubtedly destroyed some canal segments and related structures. Nonetheless, future systematic investigation of the acequias could prove informative. 


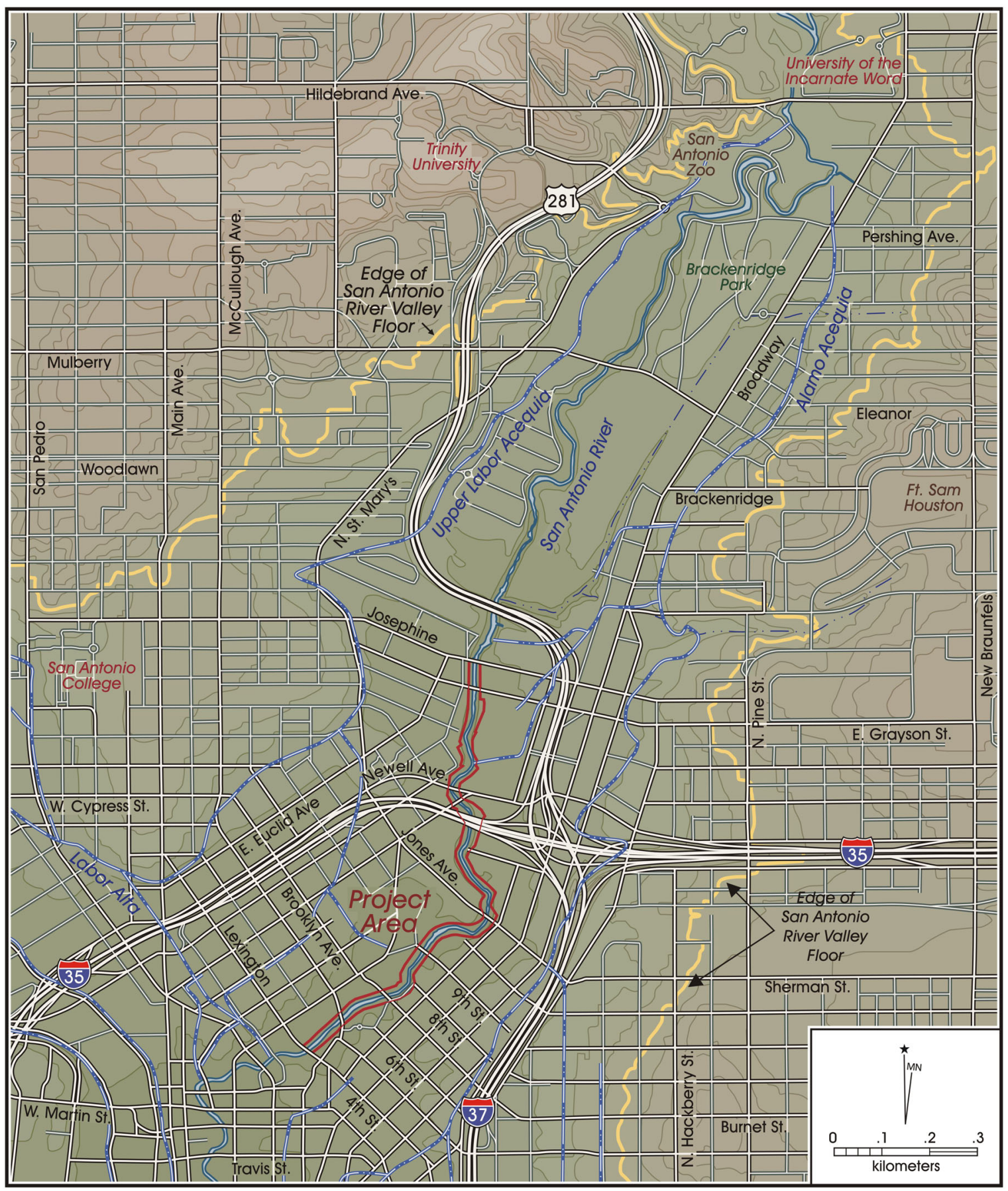

Figure 4-11. Road alignments reflecting Spanish water-distribution network. 


\section{Prehistoric and Early Historic Landscape and Strata}

Our information regarding the ancient deposits of the San Antonio River flood terrace is from BHT8 and 17 of the boreholes, at locations throughout the project area. Thickness of the Quaternary section (exclusive of historical and modern fill) varies from approximately 4 to $10 \mathrm{~m}$ (Table B-1). Beneath the historical fill, there is a generally upwardfining stratigraphic sequence consisting of coarse-grained channel deposits of Late Pleistocene and early to middle Holocene age, middle and late Holocene channel-margin deposits of variable texture, and fine-grained middle to late Holocene and modern overbank and palustrine (marsh) deposits (Tables A-2 and B-1; Figures 4-9 and 4-10). Each of the boreholes reached the subjacent bedrock, a weakly consolidated Upper Cretaceous mudstone, the Marlbrook Formation (upper Taylor Group; Brown et al. 1983). This calcareous to gypsiferous mudstone weathers deeply, producing a saprolite as much as $10 \mathrm{~m}$ thick, which can resemble fine-grained fluvial deposits when examined as borehole samples. The contact (erosional unconformity) between the weathered bedrock and Late Pleistocene or early Holocene channel deposits may lie as deep as $11.6 \mathrm{~m}$ and as shallow as $4.9 \mathrm{~m}$ below the surface (Table B-1).

\section{Basal Channel Deposits}

The basal channel deposits typically range from 2 to $4 \mathrm{~m}$ in thickness (Figure 4-10). Most of these strata consist of gravel, sandy or clayey gravel, or gravelly clay. In contrast, B-23 appears to have been drilled into an abandoned channel that filled with $2.6 \mathrm{~m}$ of clay and gravelly to sandy clay before the main channel shifted back to that location. A sample of clay from 7.0 to $7.6 \mathrm{~m}$ in depth-just above the bedrock contact - in B-23 yielded the oldest radiocarbon age of any of the samples from the Museum Reach, 18,070 \pm 560 BP (Tables B-1 and B-2). The $\delta^{13} \mathrm{C}$ value for the organic carbon from this sample was $-29.0 \%$, which is extremely depleted and much lower than the values for the other samples. In most fluvial deposits, the organic matter is a mixture of plant debris of slightly different ages from riparian vegetation and upland flora throughout the upper watershed. Plant materials decompose at different rates: the more reactive components typically yield relatively enriched values and younger ages and the more durable components produce comparatively depleted values and older ages (Wang et al. 2003:354). The durable material is often part of the organic matter originally deposited with the inorganic sediment and thus reflects the time of deposition of that stratum; whereas reactive material is mobile and tends to accumulate through pedogenesis, thus signifying the time of post-depositional soil development.

The bedrock below $7.6 \mathrm{~m}$ in depth in B-23 is deeply weathered and appears to have developed a soil, but this soil is evidently so old that most of its reactive organic matter has decomposed. Some of the residual, depleted carbon may have been incorporated into the sediment initially filling the channel, which was scoured into the weathered bedrock prior to its abandonment. Whether the radiocarbon age most closely represents the beginning of channel infilling or the end of soil development on the bedrock surface, preceding infilling, is unclear. The age difference between these events may, in fact, be small and laterally variable. Although both the radiocarbon age and $\delta^{13} \mathrm{C}$ value appear somewhat anomalous, both are credible (see additional evaluation and discussion of these analytical results in the section on radiocarbon ages and $\delta^{13} \mathrm{C}$ values below). This is the only radiocarbon sample from the basal channel deposits. Interpolating between this Late Pleistocene age and the ages of the next deepest samples indicates that the age of the channel deposits below the flood terrace are Late Pleistocene and early to middle Holocene. Late Holocene to modern channel deposits can be found within the existing (and pre-rectification) channels.

\section{Channel-Margin Deposits}

Overlying the coarse channel sediment and fine-grained abandoned-channel deposits are 2 to $4 \mathrm{~m}$ of generally sandy to sandy-gravelly channel-margin deposits. Channel-margin deposits accumulate within the transition zone between the channel and the floodplain, primarily during major floods. Relatively coarse, mixed-texture sediment is deposited along the bank as bar and lateral-accretion sequences, and is occasionally pushed onto the edge of the floodplain, creating levees and similar features. Channel rectification and artificial filling and leveling probably destroyed landforms of this type, but the deposits are preserved and recognizable. The age of these strata varies across the landscape, ranging from Late Pleistocene and early Holocene to modern, although most of the channel-margin deposits examined during this investigation are probably early to middle Holocene. The reason for this is that the boreholes were drilled on the flood terrace, usually some distance from the modern channel margin. Most late Holocene to modern channel-margin deposits would be found closer to the existing channel. Because the channel was realigned artificially, however, a few boreholes were in fact drilled close to the historical position of the river, and penetrated channel-margin deposits of late Holocene 
age. Coarse sediment at the base of the Quaternary section is generally considered a channel deposit because the bedrock contact represents the lowest point in the fluvial depositional environment, i.e., the ancestral channel. In fact, some of the basal channel deposits may have accumulated as channel-margin sediment during the Late Pleistocene to early Holocene. The only radiocarbon sample from deposits of this type is Sample 4 from B-63: $2930 \pm 70$ BP (Tables B-1 and B-2; Figure 4-10). This age is very nearly middle Holocene (nominally 3333 to $6666 \mathrm{BP}$ ), and we may infer that most of the channel-margin deposits are early to middle Holocene in age because they lie between dated Late Pleistocene and late Holocene strata.

\section{Floodplain/Flood-Terrace and Palustrine Deposits}

The vertical sequence of deposits beneath most floodplains/ terraces varies upward from coarse to fine overall. In the normal evolution of rivers and streams in the Western Gulf Coastal Plain, a channel migrates laterally across its valley floor for extended periods in a state of dynamic equilibrium. The basal floodplain deposits are thus an amalgam of the coarse-grained bedload of the shifting channel. Floodplains and flood terraces are, however, typically capped with finegrained overbank deposits. As flood waters rise above the river banks, the top of the water column spreads through the adjacent flat terrain. This process dissipates the flood's energy, causing sediment to fall out of suspension almost immediately. Only fine-grained mineral and organic sediment is transported in suspension and it is this sediment that accretes on floodplains and flood terraces. Coarse sediment is transported primarily as bedload and is confined to the channel and channel margin except during extreme floods. Because floodplains are low-lying landforms, they are subjected to frequent inundation, and deposition is therefore relatively rapid. Archaeological features are often preserved on floodplains and flood terraces because the river or stream is a locus of human activity and conditions favor frequent sedimentation and rapid burial without significant erosion or site disturbance.

Palustrine deposits are demonstrative of special conditions. In particular, the location must be persistently wet. If the water is shallow and relatively slow moving, aquatic and/ or riparian vegetation may be abundant; yet marsh environments can exist where there is generally no aboveground water if the substrate remains water-saturated. Marsh plants grow quickly and organic matter may accumulate faster than its rate of decomposition. Water saturation actually inhibits some types of chemical and biological decomposition by preventing atmospheric exchange and oxidation. Organicrich palustrine sediment is typically fine-grained because the rate of water flow is often slow in contexts that favor marsh flora.

If the upper San Antonio River valley was a cienega prior to artificial development of its water resources, palustrine deposits should be widespread. At least some probable palustrine deposits were found during the course of this investigation. Backhoe Trench 8 exposed brown, comparatively organic-rich, silty clays with calcareous rhyzoconcretions (Stratum 4, Bk horizon; Table A-2; Figure 4-9). Rhyzoconcretions are mineral deposits that fill cavities created by roots. They are common in palustrine deposits, especially where the soil water contained a high concentration of dissolved calcium carbonate. Spring waters discharged from the Edwards limestone aquifer are highly calcareous and may precipitate calcium carbonate in some contexts. The radiocarbon age of the palustrine deposits in BHT8 is $3580 \pm 70 \mathrm{BP}$, which is middle Holocene (Tables A-2 and B-2; Figures 4-9 and 4-10). There is yet other evidence. Ostracodes are aquatic arthropods with paired clam-like shells (known as valves) and are abundant in marshes. A few ostracode valves were found in a sample from 1.2 to $1.8 \mathrm{~m}$ in depth in B-63 (Table B-1). A radiocarbon sample from 1.8 to $2.4 \mathrm{~m}$ in depth in B-63 yielded an age of $1990 \pm 70 \mathrm{BP}$, late Holocene (Tables B-1 and B-2). Marshes are the most likely environments in which ostracodes would be found and preserved in the San Antonio River valley. Small marshes exist even today along the river banks and were probably much more expansive in the past. Regardless of whether a large cienega existed at San Antonio Springs, marshes may have been present elsewhere in the upper valley.

\section{Radiocarbon Ages}

Thirteen radiocarbon ages were obtained on soil/sediment organic humate from samples collected at BHT8 and B-2, B-23, and B-63 (Table B-2). Assays were performed on three or four samples from each locality. Within these local sequences, the ages were stratigraphically coherent (increase with depth), and samples from comparable depths at different localities had similar ages. As a result, the ages appear to warrant a high level of confidence, but this conclusion may be tested by plotting the assays on age:depth graphs (Figures 4-12 and 4-13). In Figure 4-13, the ages of samples from each locality were plotted separately. Sample 3 from B-23 (18.070 BP, 7.0-7.6 m depth) was excluded because it fell far outside the age and depth ranges for the other samples. Least-squares testing (linear regression) 
provides a measure of the agreement in the data. Ideally, the assays should plot along a straight line that, if extended, would intersect the Y-axis at coordinates $(0.0,0.0)$. This would mean that sedimentation was continuous and there were no gaps in the profile caused by erosion or other processes. Likewise, mixing of carbon of different ages would be contraindicated.

The formula for the least-squares trendline has the form

$$
\mathbf{Y}=\mathbf{b X}+\mathbf{a}
$$

where $\mathbf{Y}$ is the mean depth of the sample in meters below ground surface, $\mathbf{b}$ is the slope of the trendline, a measure of the change in depth per unit time, $\mathbf{X}$ is the conventional radiocarbon age in years before present (YBP), and $\mathbf{a}$ is the Y-intercept. An additional, calculated factor, the coefficient of determination, $\mathbf{R}^{2}$, expresses the degree of scatter among the data, where 1.0 is perfect. The trendline for samples from B-23 (excluding Sample 3) had an $\mathrm{R}^{2}$ of 1.0 because there were only two samples and two points always define a straight line. Samples from BHT8 had an $\mathrm{R}^{2}$ of 0.9854 , which is very close to 1.0. The Y-intercept for this line, -0.4628 , is also nearly ideal, indicating continuous deposition at an essentially constant rate from 3580 years ago to the present (point 0.0,0.0). Because the upper 65 $\mathrm{cm}$ of deposits at BHT8 are artificial fill (not covered by the trendline), the similarity between its average rate of aggradation and the natural rate of overbank sedimentation must be considered fortuitous. In this kind of graph, a negative Y-intercept and steep slope mean that the samples

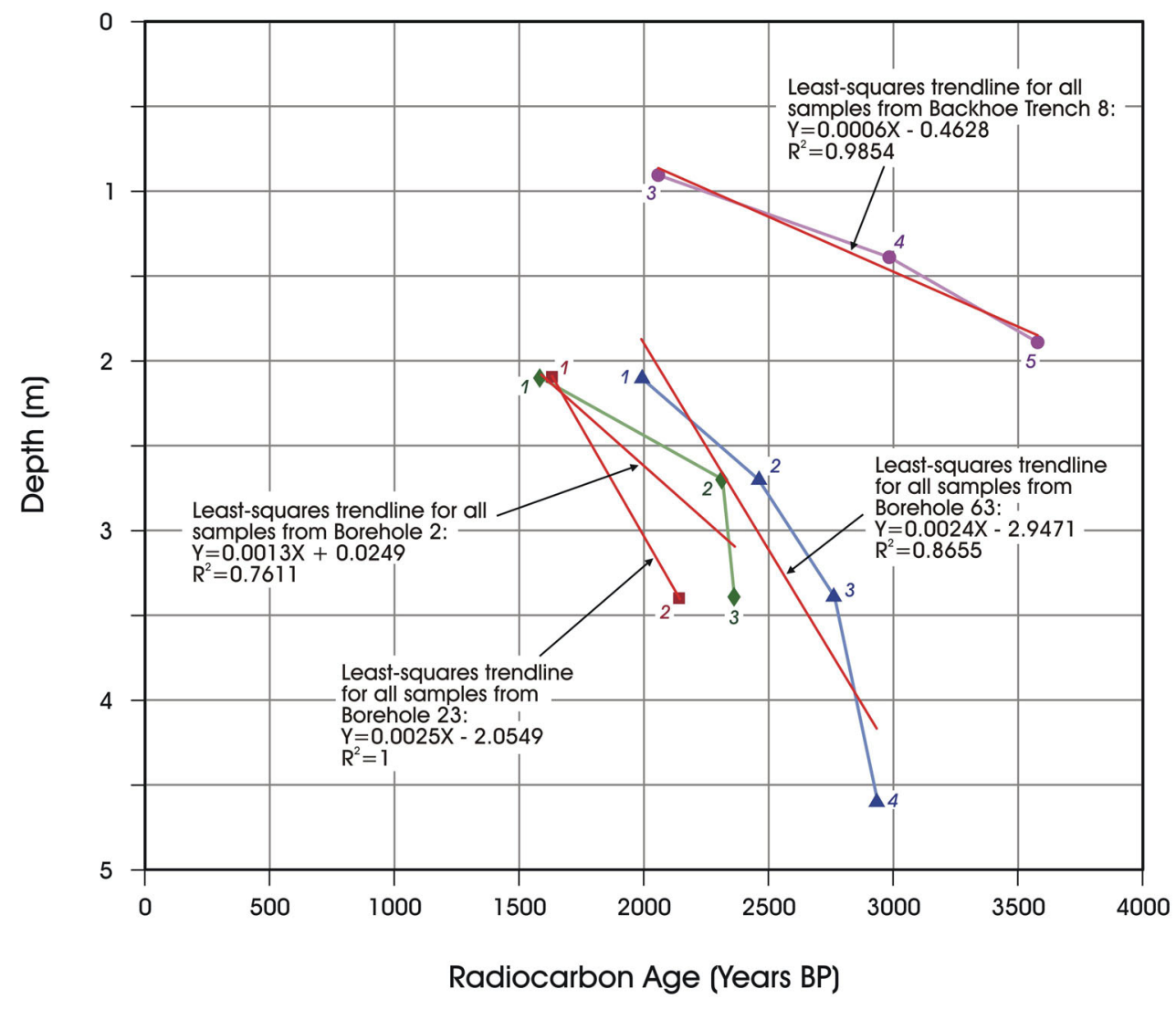

Figure 4-12. Age:depth relationships, Boreholes 2, 23, and 63, and Backhoe Trench 8. 


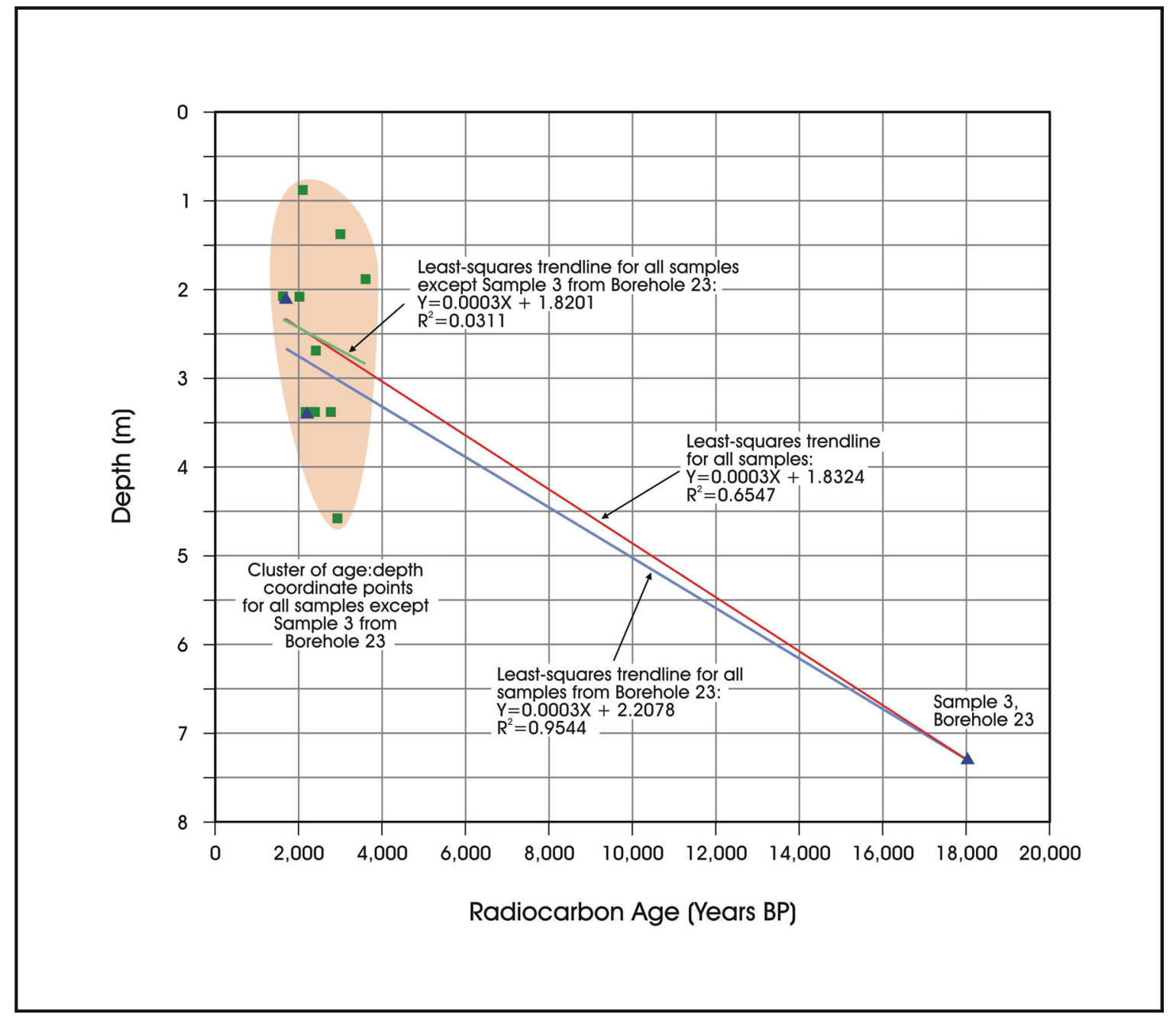

Figure 4-13. Age:depth relationships, all samples.

originated at a greater depth than might be expected given their radiocarbon age. It is also true that the sediment at a given depth is younger than anticipated. Steep slopes and Y-intercepts of strongly negative value are caused by downward infiltration of young organic matter, skewing the ages. This occurs most commonly in response to bioturbation and/or soil development. A moderately steep slope, 0.0024, and the most divergent Y-intercept, -2.9471, were calculated for the four samples from B-63. Those data produced an intermediate $\mathrm{R}^{2}$ value, 0.8655, as well. Formulae for the trendlines of B-63 and B-23 are much alike, as are those for BHT8 and B-2. Samples from B-2 had the lowest $\mathrm{R}^{2}, 0.7611$. Although there is considerable scatter in these age:depth coordinates, the Y-intercept, +0.0249 , is slightly positive and the lowest among these data sets. The effect of young carbon contaminants appears to increase with depth, perhaps because the Quaternary section is comparatively thin at this locality and near-surface carbon can therefore infiltrate to depth more easily.

The second graph explores data trends when all of the radiocarbon assays are combined (Figure 4-13). The ages of all samples except Sample 3 from B-23 are clustered on the left side of the graph between approximately 1600 and $3600 \mathrm{BP}$, but their age:depth coordinates exhibit considerable scatter. The $\mathrm{R}^{2}$ for the trendline for all samples except Sample 3 in B-23 is extremely low, 0.0311. This line has a low slope, 0.0003 , but a moderate Y-intercept, +1.8201 . Perhaps surprisingly, this line is virtually identical to those for all samples, including Sample 3 from B-23. These lines can, therefore, be used to predict radiocarbon ages at various depths, although the precision of these 
estimates vary considerably for shallow versus deep strata. One important finding is that the line for B-23 has a very high $\mathrm{R}^{2}$, which indicates that the sedimentation rate was stable from the Late Pleistocene to the late Holocene. The Y-intercept is also moderately high and positive, possibly reflecting ongoing addition of somewhat older, but nearly contemporaneous carbon from the saprolite on the underlying bedrock and from sources upstream. This would help explain the very depleted $\delta^{13} \mathrm{C}$ ratio for Sample 3 . Contamination with old, even radiocarbon-extinct carbon has a relatively small effect on most samples from Holocene deposits. Because radiocarbon decay is a geometric progression, a far greater effect is felt when the contaminant is younger. These observations serve to corroborate the age of Sample 3 from B-23, the oldest sample assayed. The chronology is, overall, representative of the Museum Reach as a whole. Establishing a well constrained radiocarbon chronology for Quaternary deposits within the upper San Antonio River valley is, by itself, a significant contribution to our understanding of geomorphic and depositional processes in this region.

\section{Carbon Stable-Isotope Ratios}

Carbon stable-isotope ratios were measured for each of the radiocarbon samples. The ratio is used to make a normally small correction of the measured radiocarbon age. The corrected age is known as the conventional radiocarbon age (also called the $\delta^{13} \mathrm{C}$-corrected age), and it is this number that is used routinely in discussions of chronology. The range of $\delta^{13} \mathrm{C}$ values for 12 of the 13 samples (exclusive of Sample 3 from B-23) is -17.4 to $-22.2 \%$, a $4.8 \%$ variation. Sample 3 from B-23 had a $\delta^{13} \mathrm{C}$ value of $-29.0 \%$, which is unusually depleted - that is, the concentration of the heavier ${ }^{13} \mathrm{C}$ isotope is low relative to that of lighter, but more abundant ${ }^{12} \mathrm{C}$. In addition to providing a means of adjusting measured radiocarbon ages, the $\delta^{13} \mathrm{C}$ ratio is an indicator of the composition and source of the organic carbon in the sample. Most of the organic carbon in fluvial deposits derives from plant detritus (leaves, twigs, etc.) that is deposited with the inorganic sediment or infiltrates during soil development. The detrital carbon is from vegetation growing within the riparian corridor (along the channel and on the floodplain) and/or in upland areas within that part of the watershed that is upstream from the site of deposition of the sediment.

In terms of their isotopic ratios, there are three broad categories of plants, characterized by differences in their photosynthetic processes. The most common type is known as $\mathrm{C}_{3}$ photosynthesis, which imparts a $\delta^{13} \mathrm{C}$ ratio of -32 to $-20 \%$, with a mean of $-27 \%$ (Boutton 1991:177). Values as low as -29 to $-32 \%$ are uncommon, which is why the analysis of Sample 3 from B-23 was conspicuous and raised concern over possible contamination. Temperate grasses and most trees and aquatic plants employ $\mathrm{C}_{3}$ photosynthesis. In contrast, warm-season grasses and a few subtropical and tropical trees utilize $\mathrm{C}_{4}$ photosynthesis, which produces $\delta^{13} \mathrm{C}$ values of -17 to $-9 \%$, with a mean of $-13 \%$. The final group includes the Cactaceae and Euphorbiaceae (cactuses and spurges) and some submerged aquatic plants, which apply the CAM process. CAM plants have $\delta^{13} \mathrm{C}$ ratios of -28 to $-10 \%$, although most have values of -20 to $-10 \%$.

The isotopic composition of organic matter in the soil or sediment closely corresponds to that of the plants contributing the detritus. If the detritus is from more than one type of plant, the $\delta^{13} \mathrm{C}$ ratio for the sample is an intermediate value, based on the proportional contribution from each. For example, if $70 \%$ of the carbon in a sample is from $\mathrm{C}_{3}$ plants with a value of $-27 \%$ and $30 \%$ is from $\mathrm{C}_{4}$ plants with a $\delta^{13} \mathrm{C}$ ratio of $-13 \%$, the combined value is $-22.8 \%$. Among the samples from the Museum Reach, all have $\delta^{13} \mathrm{C}$ ratios representing at least partial mixing of carbon from $\mathrm{C}_{3}$ and $\mathrm{C}_{4}$ sources. Riparian vegetation would be dominated by $\mathrm{C}_{3}$ plants, whereas $\mathrm{C}_{4}$ species might be more abundant in upland areas. CAM plants are not likely to have made significant contributions. Considering the range of measured isotopic ratios in these samples, it is probable that upland grasses were a major source of organic carbon. A sample with a $\delta^{13} \mathrm{C}$ ratio of $-17.4 \%$, the most enriched value reported, may have received $68.5 \%$ of its carbon from $\mathrm{C}_{4}$ species. The depleted value $-22.2 \%$ may indicate that $66 \%$ of the carbon is from $\mathrm{C}_{3}$ plants.

In a fluvial context, radiocarbon samples with $\delta^{13} \mathrm{C}$ values close to those of riparian flora may be somewhat more reliable in that the carbon came primarily from proximal sources that were contemporaneous with the deposits. Carbon from the surrounding uplands must have been eroded and redeposited and thus may be older. In fact, this pattern has been widely observed and may indicate a tendency for humates in fluvial sediment to yield radiocarbon ages that are slightly older than the actual time of deposition of the sediment. This process, known as the soilreservoir effect, may produce ages that are a few hundred to a few thousand years too old (Birkeland 1984:150-151; Wang et al. 2003:348-349). This effect is, presumably, lessened when a majority of the carbon is from riparian sources. Although $\mathrm{C}_{3}$ plants are predominant in the riparian 
corridor along the San Antonio River, $\mathrm{C}_{3}$ trees and other species are present in the uplands as well, and thus may have affected the results of the radiocarbon assays. Fortunately, the stratigraphic coherence of the radiocarbon ages and convergence of the regressions indicates that contamination of these samples was probably minimal (Table B-2; Figures 4-12 and 4-13). Sample 3 from B-23 presents a special problem: did some of the organic carbon come from the soil developed on the subjacent weathered bedrock and therefore represent a contaminant? The $\delta^{13} \mathrm{C}$ value is strongly depleted, but still within the range for $\mathrm{C}_{3}$ plants. One possibility is that much of the carbon was from phytoplankton and aquatic macrophytes (water plants), most of which are $\mathrm{C}_{3}$ species, but have $\delta^{13} \mathrm{C}$ ratios even more depleted than many of their terrestrial counterparts (Boutton 1991:181). The sampled deposits accumulated near the bottom of an abandoned channel, which may have formed an oxbow lake or similar environment in which aquatic flora and microflora were the primary carbon sources, at least initially. Under these conditions, the radiocarbon age and $\delta^{13} \mathrm{C}$ value would be entirely representative. In the absence of other evidence, the radiocarbon age of Sample 3 from B-23 is accepted.

\section{Palynological Data}

V. M. Bryant analyzed 15 samples for pollen, of which 13 were splits from the radiocarbon samples (Appendix C). The results of the palynological investigation confirmed the often-reported absence of pollen preservation in southcentral Texas (Bryant and Holloway 1985). Few pollen grains were recovered and their condition was poor. Recovery was so sparse that the report did not provide locality- or sample-specific data. Pollen that was identified included Pinus sp. (pine tree, probably wind blown from distant sources); Celtis sp. and Quercus sp. (hackberry and oak trees, respectively, species of which are common in both the riparian woodlands and upland savannahs); Carya sp. (pecan, a tree largely restricted to riparian woodlands); and Poaceae, Asteraceae, and ChenopodiaceaeAmaranthaceae (grass, sunflower, and goosefoot-amaranth families, respectively, consisting of herbaceous species primarily found in the uplands). The report gave no evidence regarding the relative concentration of each, and because there was no indication of which samples contained pollen, the age of the few preserved grains cannot be determined. All of the reported taxa are common in the project area today (Turner et al. 2003). We can provide no evidence regarding their presence or frequency in the geologic past.

\section{Cultural-Resource Potential}

As stated previously, floodplains and flood terraces are often ideal settings for rapid burial and preservation of cultural resources. The frequency of low-energy sedimentation would serve to isolate the materials from individual occupations. This process also has the effect of diluting site density by separating the cultural assemblages vertically, thereby reducing the likelihood of site discovery. Rapid burial may also afford a false impression that a site was not occupied continually. In these geomorphic contexts, numerous, deep excavations are the only effective means of assessing cultural-resource potential.

Despite these conditions favorable for site preservation, no cultural materials older than the late 1800 s were found during the present investigation of the Museum Reach. Our efforts were hampered by the difficulty of accessing localities suitable for backhoe trenching and by the universal presence of thick, late historical to modern fill. Although the eight trenches excavated within the project area represent a minimal effort, additional or deeper trenching would have been impracticable. Considerable stratigraphic and chronological data were obtained from examination of the borehole samples, but the small area of coverage of individual boreholes provided virtually no test of the presence or absence of buried sites. What can be said is that, potentially, cultural deposits of Late Pleistocene to Holocene age cover the entire flood terrace and are as much as $10 \mathrm{~m}$ thick. Further testing of this area would require broadened property access and utilization of deep excavators. Special effort should be devoted to exploration for Spanish Colonial water-management and agricultural features.

\section{Conclusions}

Thick fluvial and related deposits are present throughout the project area, spanning the period from Late Pleistocene to the present. Prehistoric and early historic sites may be preserved, but the current investigation has shown that the Museum Reach contains few locations suitable for a thorough assessment of buried cultural resources. No sites or cultural materials predating the late nineteenth century were found. Although the practical limitations on testing were a contributing factor, it is also probable that channel modification and incompatible land use have destroyed many sites, particularly the Spanish acequias and related water-distribution systems. The flood-terrace deposits do, however, retain an important record of landscape evolution 
and Quaternary paleoenvironmental conditions within the upper San Antonio River valley. This record has important implications regarding the lifeways of ancient peoples and the pace and process of European colonization. The dense matrix of engineering boreholes provided a portrait of Quaternary stratigraphy from the northern end of the Museum Reach to its farthest downstream extent. Ready access to samples from depths normally well beyond those reached during geoarchaeological investigations presented an opportunity for investigating paleoenvironmental conditions that may never be duplicated.

\section{Recommendations for Future Investigations}

The results of the present study demonstrate the difficulty of conducting geoarchaeological assessments in the narrow, urbanized confines of the Museum Reach. Future investigations should provide improved access and perhaps allow testing at locations near but outside of the proposed construction area. The necessity of deep testing means that large-scale excavators would be required; however, the shallow water table may impose a practical limit on the depth to which surface excavations may be opened. Coring would provide a partial solution and could perhaps be conducted in conjunction with geotechnical drilling.

We offer the following additional recommendations:

1. Curate the remaining borehole samples and records for future investigations. The present database could be expanded by analyzing additional samples and/or performing other analyses using the existing cores.

2. Conduct the investigation of other reaches along the San Antonio River following the model of the present assessment, but providing improved access to project areas.

3. Integrate geoarchaeological and geotechnical data collection during borehole drilling and/or ensure retention and proper curation of core samples collected independent of the geoarchaeological study. 


\section{Chapter 5: Conclusions and Recommendations}

During the spring and fall of 2005, CAR conducted reconnaissance and intensive archaeological pedestrian survey and geomorphologic investigations of the Museum "Urban" Reach portion of the San Antonio River Improvements Project in San Antonio, Bexar County, Texas. The San Antonio River Improvements Project is comprised of a southern "Historical" Mission Reach and a northern Museum Reach that consists of the "Urban" and "Park" sections. This report and the work reported herein focused on the "Urban" section that extends from Josephine Street to Lexington Avenue. The archaeological and geomorphologic work consisted of reconnaissance, backhoe trenching, and auger boring conducted within the project area.

The ROW of the project area, and therefore the project APE, consists of the active river channel and narrow strips of bank and floodplain along both sides of the channel. The active channel does not run down the center of this ROW, creating situations where the majority of the dry-land portion of the ROW occurs either on the east- or west-descending bank of the river. At its widest point, the project ROW is $150 \mathrm{ft}$. (approximately $46 \mathrm{~m}$ ) wide while at its narrowest point, the ROW measures approximately $75 \mathrm{ft}$. (approximately $24 \mathrm{~m}$ ) in maximum width. With the active channel taking up 20-30 ft. of the APE, often the width of the combined (i.e., east- and west-descending banks) dry-land portion of the ROW was only $45-120 \mathrm{ft}$.

Prior to the inception of the reconnaissance and survey, CAR carried out a comprehensive historic resources inventory review. Part of this review was coupled with the work conducted by Mainstreet Architects, Inc. for the Standing Structure Survey that was a secondary principal aspect of the project (Mainstreet Architects, Inc. 2005). The results of the Standing Structure Survey are reported in a separate document. Of the 51 structures reviewed in the Historic Resources Inventory, 23 contained structures that predate 1955. Among these are several properties that are significant local landmarks in San Antonio. For instance, the Pearl Brewing Company (Historic Resource \#38) and the Lone Star Brewing Company (Historic Resource \#22) are renowned breweries in Texas history. Historic Resource \#13, located in the "Irish Flats" of San Antonio, is significant due to its location and historical use as the residence of the Lone Star Brewery brew master. Taco Land (Historic Resource \#46) is another significant San Antonio landmark.
Though the construction period of several of the standing structures was estimated by architectural means, the historical use of a majority of the standing structures and properties is unknown. The historic structures that were once along the project area may have been removed to make way for newer structures. Many properties have been utilized since the late 1800 s, and possibly earlier by indigenous groups. In addition to these standing structures, historic records indicate that one Colonial Period feature, an outflow canal of the Acequia Madre entered the river somewhere at the southern end of the Pearl Brewery complex north of Newell Avenue on the east bank of the river. The area has been heavily impacted by a modern sewer outlet and the archaeological survey noted no sign of the canal. Nonetheless, it is possible that subsurface impacts in the area could reveal any remaining portions of the canal.

The archaeological reconnaissance and pedestrian survey revealed that portions of the project ROW are heavily impacted by modern alterations of the banks of the river including concrete embankments, bridge construction, and landscape-related modifications. The reconnaissance indicated that there are two river channel profiles predominant within the project area; both of them are the product of extensive channelization of the river either to remove meanders from the original stream channel or widen the existing channel to accommodate greater streamflow. Both of these modifications resulted in dramatic impacts to any potential archaeological resources that may have been found on the immediate banks of the stream, or on its floodplain where new channel segments were excavated.

The reconnaissance of the APE conducted by CAR personnel did not identify any surface archaeological deposits along the ROW. The low terrace sits only about 4-7 ft. above the waterline and is covered with dense secondary growth; the deposits that may have had cultural materials were removed either through channelization or the widening of the active channel. The upper terrace that is $10-17 \mathrm{ft}$. above the waterline is the original floodplain surface but it is present within the project ROW only as narrow strips rising from the lower terrace and abutting property fence lines. Archaeological deposits were not noted on the slope connecting the two terraces. While short and narrow segments of the upper terrace are preserved in other portions of the project area, these segments are usually 
not accessible from street level, rather, one would have to access them from the lower terrace of the river and in most instances the insertion of heavy equipment would be difficult and dangerous, if at all possible.

Three areas that retain portions of the upper terrace sufficiently wide enough to allow subsurface inspection for buried archaeological deposits were identified during the reconnaissance. The northernmost of these locations is on the west-descending bank of the river between East Myrtle Street and Newell Avenue just east of Schiller Street. It is immediately across from the acequia outflow and current location of a sewer main that crossed under the Pearl Brewery. The locality is immediately south of one of the meanders that was cut through by channelization efforts. The second location, also on the west-descending bank, begins immediately south of West Jones Avenue and is immediately north of a section that was straightened through channelization. The third location where a section of the upper terrace of the San Antonio River is preserved and accessible for subsurface investigations is located immediately north of Ninth Street on the west-descending bank. This section is in a channelized portion of the river, well away from the original channel that flowed west of its current location.

The geomorphologic investigations have showed that thick fluvial and related deposits discovered throughout the project area appear to span the entire period from Late Pleistocene to late Holocene. Although prehistoric and early historic sites may be preserved, the present investigation has shown that the Museum Reach contains few locations suitable for a thorough assessment of buried cultural resources. No sites or cultural materials predating the late nineteenth century were found, probably because of active site destruction through channel modification and incompatible land use.

Several soil samples were extracted from backhoe trench profiles, intended to be used for pollen analysis and radiocarbon dating. The results of the pollen analyses were disappointing in that pollen and/or phytolith preservation was poor and did not allow a reconstruction of the vegetation history of the upper San Antonio River basin. Nonetheless, the cursory review of the results indicates that portions (i.e., pockets of sediments) of the project area sampled either through backhoe trenching and/or geotechnical borings do contain long continuous depositional sequences. Such select areas may have potential for reconstructions of long paleoenvironmental sequences, provided that pollen and/or phytolith preservation is favorable. Unfortunately, none of the areas identified to date contain associated cultural deposits.

Overall, the historic background research has identified several historic properties that consist of standing structures that represent significant historic resources within the immediate vicinity of the project ROW. These resources are more fully discussed in a Standing Structure Survey report that is a second deliverable under this project. The likely location of an outflow canal or desague of the Acequia Madre also has been identified during archival research near the southern end of the Pearl Brewery complex north of Newell Avenue on the east bank of the river. Nonetheless, the reconnaissance of the project area and the intensive pedestrian survey and geomorphologic investigations did not identify signs of the canal or intact cultural deposits within the project area. The lack of intact prehistoric and/ or historic deposits is likely due to the extensive disturbances that are the products of stream channelization and channel widening that have occurred during the first half of the twentieth century. It is the recommendation of CAR that the construction project proceed as planned due to the absence of intact historic resources within the project area. We also recommend that the several standing structure historic resources in the vicinity of the project ROW proper be incorporated into the project's conceptual plans to take advantage of the rich historic context offered by the river. We anticipate no visual impact to any of the standing historic structures and resources identified outside but in the vicinity of the project boundaries during the Standing Structures Survey along the project area. This conclusion derives from the fact that the large majority of the improvements along the banks of the river will occur below the level of the banks and will consist of the construction of multi-use pathways, pedestrian pathways and bridges, planted areas, barge turning and passing basins, boat landing sites, access steps and ramps, docks, and a dam.

Finally, given the significant role the river has played in the historic fabric of San Antonio, we cannot assume that evidence of historic or prehistoric sites may not be present in hitherto undiscovered locations along the project ROW. While modern disturbances systematically extend to 24 inches below the current surface, undisturbed deposits may be found in selected localities along the project ROW. Therefore, we recommend that archaeological monitoring be conducted during any subsurface disturbances that 
extend deeper than two feet below the current surface whether they occur within the ROW proper or immediately outside of it and are related to utility tie-ins. In addition, given the known location of an outflow of the Acequia Madre within the project boundaries, we specifically recommend the need for monitoring of subsurface construction work within the vicinity of this locality to ensure that any remaining portions of this acequia are properly documented. 


\section{References Cited}

Answers.com

2006 Online dictionary, http://www.answers.com, accessed January 2006.

Bacon, D.

2005 Geotechnical engineering study, San Antonio River Improvements Project, Museum Reach: San Antonio, Texas. Manuscript on file, Arias and Associates, Inc., San Antonio, Texas.

Bates, R. L., and J. A. Jackson (editors)

1980 Glossary of Geology. 2nd edition. American Geological Institute. Falls Church, Virginia.

Bexar County Appraisal District [BCAD]

2006 Archives. Electronic database, http://bcad.org/, accessed January, 2006.

\section{Bexar County Clerk [BCC]}

2006a Public deed records, Book 201, p. 415. Electronic database, http://www.countyclerk.bexar.landata.com/, accessed February, 2006.

2006b Spanish Archives, Volume 3, p. 317-340. Electronic database, http://www.countyclerk.bexar.landata.com/, accessed February, 2006.

2006c Public deed records, Book A2, p. 298 and Book H1, p. 268. Electronic database, http://www.countyclerk.bexar. landata.com/, accessed February, 2006.

2006d Public deed records, Book M2, p. 38. Electronic database, http://www.countyclerk.bexar.landata.com/, accessed February, 2006.

2006e Public deed records, Book 2867, p. 46. Electronic database, http://www.countyclerk.bexar.landata.com/, accessed February, 2006.

$2006 \mathrm{f}$ Public deed records, Book 4809, p. 271. Electronic database, http://www.countyclerk.bexar.landata.com/, accessed February, 2006.

2006g Public deed records, Book 4871, p. 104. Electronic database, http://www.countyclerk.bexar.landata.com/, accessed February, 2006.

2006h Public deed records, Book 6793, p. 1506. Electronic database, http://www.countyclerk.bexar.landata.com/, accessed February, 2006.

2006i Public deed records, Book 11259, p. 1758. Electronic database, http://www.countyclerk.bexar.landata.com/, accessed February, 2006.

2006j Public deed records, Book 7258, p. 1030. Electronic database, http://www.countyclerk.bexar.landata.com/, accessed February, 2006.

2006k Public deed records, Book 1999, p. 164. Electronic database, http://www.countyclerk.bexar.landata.com/, accessed February, 2006.

20061 Public deed records, Book 199, p. 301. Electronic database, http://www.countyclerk.bexar.landata.com/, accessed February, 2006.

2006m Public deed records, Book 193, p. 26. Electronic database, http://www.countyclerk.bexar.landata.com/, accessed February, 2006.

2006n Public deed records, Book 273, p. 372. Electronic database, http://www.countyclerk.bexar.landata.com/, accessed February, 2006.

2006 o Public deed records, Book 1719, p. 221. Electronic database, http://www.countyclerk.bexar.landata.com/, accessed May, 2006.

2006p Public deed records, Book 309, p. 250. Electronic database, http://www.countyclerk.bexar.landata.com/, accessed May, 2006. 
2006q Public deed records. Book 2395, p. 509. Electronic database, http://www.countyclerk.bexar.landata.com/, accessed February, 2006.

$2006 \mathrm{r}$ Public deed records, Book 14, p. 10. Electronic database, http://www.countyclerk.bexar.landata.com/, accessed February, 2006.

2006s Public deed records, Volume 3427, p. 291. Electronic database, http://www.countyclerk.bexar.landata.com/, accessed February, 2006.

$2006 \mathrm{t}$ Public deed records, Book 2387, p. 38. Electronic database, http://www.countyclerk.bexar.landata.com/, accessed February, 2006.

2006u Public deed records, Book 335, p. 233. Electronic database, http://www.countyclerk.bexar.landata.com/, accessed February, 2006.

2006v Public deed records, Book 194, p. 399. Electronic database, http://www.countyclerk.bexar.landata.com/, accessed February, 2006.

2006w Public deed records, Book 2355, p. 92. Electronic database, http://www.countyclerk.bexar.landata.com/, accessed May, 2006.

2006x Public deed records, Book 2355, p. 92. Electronic database, http://www.countyclerk.bexar.landata.com/, accessed February, 2006.

2006y Public deed records, Book 2451, p. 108. Electronic database, http://www.countyclerk.bexar.landata.com/, accessed February, 2006.

$2006 z$ Public deed records, Book 2489, p. 468. Electronic database, http://www.countyclerk.bexar.landata.com/, accessed February, 2006.

2006aa Public deed records, Book 1075, p. 93. Electronic database, http://www.countyclerk.bexar.landata.com/, accessed February, 2006.

2006bb Public deed records, Book 228, p. 55. Electronic database, http://www.countyclerk.bexar.landata.com/, accessed May, 2006.

2006cc Public deed records, Book 2407, p. 566. Electronic database, http://www.countyclerk.bexar.landata.com/, accessed February, 2006.

2006dd Public deed records, Book 1489, p. 328. Electronic database, http://www.countyclerk.bexar.landata.com/, accessed February, 2006.

2006ee Public deed records, Book 2715, p. 95. Electronic database, http://www.countyclerk.bexar.landata.com/, accessed May, 2006.

2006ff Public deed records, Book 2183, p. 72. Electronic database, http://www.countyclerk.bexar.landata.com/, accessed February, 2006.

2006 gg Public deed records, Book 1339, p. 495. Electronic database, http://www.countyclerk.bexar.landata.com/, accessed February, 2006.

2006hh Public deed records, Book 4068, p. 11. Electronic database, http://www.countyclerk.bexar.landata.com/, accessed February, 2006.

2006 ii Public deed records, Book 1709, p. 37. Electronic database, http://www.countyclerk.bexar.landata.com/, accessed May, 2006.

2006jj Public deed records, Book 5919, p. 984. Electronic database, http://www.countyclerk.bexar.landata.com/, accessed May, 2006.

Birkeland, P. W.

1984 Soils and Geomorphology. Oxford University Press, New York.

Bonnell, G. W.

1964[1840] Topographical Description of Texas. To which is added an account of the Indian tribes. Reprinted. Texian Press, Austin. 
Boutton, T. W.

1991 Stable carbon isotope ratios of natural materials: II. Atmospheric, terrestrial, marine, and freshwater environments. In Carbon Isotope Techniques, edited by D. C. Coleman and B. Fry, p. 173-185. Academic Press, Inc. San Diego, California.

Brown, T. E., N. B. Waechter, and V. E. Barnes

1983 Geologic Atlas of Texas. San Antonio sheet (1:250,000-scale). The University of Texas at Austin, Bureau of Economic Geology, Austin, Texas.

Brune, G.

1975 Major and Historical Springs of Texas. Report 189, Texas Water Development Board, Austin, Texas.

1981 Springs of Texas. Vol. 1. Branch-Smith, Inc., Fort Worth, Texas.

Bryant, V. M., Jr., and R. G. Holloway

1985 A Late-Quaternary Paleoenvironmental Record of Texas-An overview of the Pollen Evidence. In Pollen Records of Late-Quaternary North American Sediments, p. 39-70. American Association of Stratigraphic Palynologists Foundation, Dallas, Texas.

Buck, S. M.

1980 Yanaguana's Successor's: The Story of the Canary Islander's Immigration into Texas in the Eighteenth Century. Reprinted. Robert M. Benavides, San Antonio.

Caran, S. C., and V. E. Baker

1986 Flooding along the Balcones Escarpment, central Texas. In The Balcones Escarpment: Geology, Hydrology, Ecology, edited by P. L. Abbott and C. M. Woodruff, Jr., pp. 1-14. Comet Reproduction Service, Santa Fe Springs, California.

Caran, S. C., and R. D. Mandel

1988 Quaternary terrace stratigraphy and geomorphology of the Texas Gulf Coastal Plain. In Geological Society of America Abstracts with Programs 20(2):93.

Caran, S. C., S. D. McCulloch, and J. Jackson

2005 Report on a Geoarcheological Investigation at the Palo Alto Battlefield National Historic Site (41CF92), Cameron County, Texas. Report No. 1, McCulloch Archeological Services LLC, San Marcos, Texas.

Chabot, F. C.

1937 With the Makers of San Antonio. Privately Published, San Antonio, Texas.

Cox, I. W.

2005 The Spanish Acequias of San Antonio. Maverick Publishing Company, San Antonio, Texas.

Cox, I. W., A. A. Fox, and S. A. Tomka

2002 San Antonio River Improvements Project, San Antonio, Bexar County, Texas Archaeological Background for the Museum Reach Project. Report on file, Center for Archaeological Research, The University of Texas at San Antonio.

Donecker, F.

1996 San Antonio River. In The New Handbook of Texas, Vol. 5, edited by R. Tyler, pp. 810-811. Texas State Historical Association, Austin, Texas. 
Fenneman, N. M.

1946 Physical Divisions of the United States. Map, 1:7,000,000-scale. United States Department of the Interior, Geological Survey, Washington, D.C.

Fisher, L. E.

1996 Saving San Antonio: The Precarious Preservation of a Heritage. Texas Tech University Press, Lubbock.

Frkuska, A. J., Jr.

1981 Archaeological Investigations at the San Pedro Acequia, San Antonio, Texas. Archaeological Survey Report No. 103. Center for Archaeological Research, The University of Texas at San Antonio.

Geological Survey

1985 State of Texas. Topographic map, 1:1,000,000-scale. United States Department of the Interior, Washington, D.C.

1992 San Antonio East, Texas. Topographic map, 1:24,000-scale. United States Department of the Interior, Washington, D.C.

Griffiths, J. F., and J. Bryan

1987 The Climates of Texas Counties. Natural Fibers Information Center, The University of Texas at Austin.

Hennech, M. C.

1996 Pearl Brewing Company. In The New Handbook of Texas, vol. 5, edited by R. Tyler, p. 110. The Texas State Historical Association, Austin.

Hill, R. T., and T. W. Vaughn

1898 Geology of the Edwards Plateau and Rio Grande Plain adjacent to Austin and San Antonio, Texas, with Reference to the Occurrence of Underground Waters. Geological Survey Annual Report 18, Part 2, pp. 193-321. United States Department of the Interior, Washington, D.C.

Jackson, A. T.

1971 Mills of Yesteryear. Texas Western Press, The University of Texas at El Paso.

Jennings, F. W.

1998 San Antonio: The Story of an Enchanted City. San Antonio Express-News, San Antonio, Texas.

Leibold, R.

2000 Article on the closing of Pearl Brewery. San Antonio Express-News, July 1.

Long, C.

1996 Fries, John M. In The New Handbook of Texas, vol. 3, edited by R. Tyler, p. 5. The Texas State Historical Association, Austin.

Mainstreet Architects, Inc.

2005 Standing Structures Survey for the specific area of the San Antonio River. Report on file, Center for Archaeological Research, The University of Texas at San Antonio.

Marten, J. A.

2006 Emergency Management. The Handbook of Texas Online. http://www.tsha.utexas.edu/handbook/online/articles/ EE/mzc1.htm, accessed December 2006. 
Olmsted, F. L.

1982[1857] A Journey Through Texas; or, A Saddle-trip on the Southwestern Frontier. University of Texas Press, Austin, Texas.

Patterson, J. L.

1965 Magnitude and Frequency of Floods in the United States. Part 8. Western Gulf of Mexico Basins. United States Department of the Interior, Geological Survey Water-Supply Paper 1682, Washington, D.C.

Salsa.net

2006 Irish Flats. Electronic document, http://www.salsa.net/peace/irishflats.html/, accessed February 2006.

Sanborn Maps

2006 Digital Sanborn Maps 1867-1970. Electronic database, http://sanborn.umi.com/, accessed February 2006.

Schuchard, E.

$1951100^{\text {th }}$ Anniversary Pioneer Flour Mills, San Antonio, Texas 1851-1951. Naylor Co., San Antonio, Texas.

Slade, R. M., Jr., and J. Patton

2003 Major and Catastrophic Storms and Floods in Texas. Geological Survey Open-File Report 03-193, Version 1.1. United States Department of the Interior, Washington, D.C.

Soil Survey Staff

1997 Official Series Descriptions, Frio and Trinity Series. Electronic database, http://soils.usda.gov/technical/ classification/osd/index.html, accessed March, 2006. United States Department of Agriculture, Natural Resources Conservation Service, Washington, D.C.

Taylor, F. B., R. B. Hailey, and D. L Richmond

1962 Soil Survey of Bexar County, Texas. United States Department of Agriculture, Soil Conservation Service, Washington, D.C.

Texas Historical Commission [THC]

2006 Texas Historic Sites Atlas. Electronic database, http://atlas.thc.state.tx.us/, accessed January, 2006.

Thoms, A. V., and R. D. Mandel (editors)

2006 Archaeological and Paleoecological Investigations at the Richard Beene Site, 41BX831, South Central Texas. Report of Investigations No. 8. Center for Ecological Archaeology, Texas A\&M University, College Station, Texas.

Tous, G. (translator)

1930 Ramon Expedition-Espinosa's Diary of 1716. Vol. I, no. IV. Preliminary Studies of the Texas Catholic Historical Society.

Turner, B. L., H. Nichols, G. Denny, and O. Doron

2003 Atlas of the Vascular Plants of Texas. Vol. 1, Introduction, Dicots. pp. 1-648. BRIT Press. Fort Worth, Texas.

Walworth, C.

2004 Texas Museum Collections: San Antonio Museum of Art. Electronic document, http://glasstire.com/features/ txmuseums_sama.htm, accessed January, 2006. 
Wang, H., K. C. Hackley, S. V. Panno, D. D. Coleman, J. C. Liu, and J. Brown 2003 Pyrolysis-combustion ${ }^{14} \mathrm{C}$ Dating of Soil Organic Matter. Quaternary Research 60:348-355.

Wright, R. E.

1996 Zambrano, José Dario. In The New Handbook of Texas, vol. 6, edited by R. Tyler, pp. 1140-1141. The Texas State Historical Association, Austin. 



\title{
Appendix A
}

\section{Stratigraphic Profiles of Backhoe Trenches}

\author{
S. Christopher Caran and Charles A. Speer
}


Table A-1. Summary of Stratigraphic Profiles Exposed in Backhoe Trenches 1 through 8 (BHT1-8)*

Jones Avenue locality: Two backhoe trenches (BHT1-2) were excavated on a large vacant (cleared) lot southwest of the northwestern end of the Jones Avenue bridge over San Antonio River, San Antonio, Bexar County, Texas. Geomorphic context: Right (northwestern) bank of river; "natural" (unrectified) channel reach; bank partly modified by filling; modified (filled and leveled) flood terrace, nearly level. Nominal soils: Trinity and Frio series (undivided). Vegetation: Dense to partly open riparian woodland, modified by urbanization, dominated by hackberry, anaqua, pecan, and live oak, with invasive non-native woody species. Land use: Former home site (cleared); ground has been leveled and river bank has been stabilized by repeated emplacement of exotic earthen fill and cultural debris; cultivated and probably irrigated historically (Cox 2005:19 map).

\section{BHT1}

UTM coordinates: Approximately $550320^{\mathrm{m}} \mathrm{E}, 3256230^{\mathrm{m}} \mathrm{N}$ (Zone $14 \mathrm{~N}$ ) (Geological Survey 1992).

Elevation: Approximately 199 m AMSL (Geological Survey 1992).

Trench dimensions: $1,020 \mathrm{~cm}$ long and $310 \mathrm{~cm}$ wide at ground level; $120 \mathrm{~cm}$ wide at depth; $250 \mathrm{~cm}$ deep.

Stratigraphy: Historical and modern fill, 250-cm exposed thickness, mostly silty sandy clay containing crushed limestone gravel, limestone boulders, and cobble- to boulder-size masses of clay. Fill appears to be vertically stratified in part, but younger fill also drapes over top of river bank, resulting in lateral stratification.

Sediment samples: None.

Artifacts: Near-surface assemblage (approximately 0- to 118-cm depth) includes low-fired yellow bricks, plastic objects, terracotta roofing tiles, fragments of clear window glass and variously colored bottle glass, aluminum cans, rusted metal objects and metal fragments, few bone fragments, metal rebars at 19- and 93-cm depths, and laid ceramic drain tiles (10-cm outside diameter) in situ at 50- and 63-cm depths, partly crushed. Deep assemblage (approximately 118- to 250-cm depth) includes low-fired yellow bricks, fragments of variously colored bottle glass and ceramic objects, whole and broken glass bottles with pointed (egg-shaped) bottoms, rusted metal objects, and metal fragments. Recovered provenienced artifacts include two complete bottles (aqua-colored glass, egg-shaped bottoms) from 130-cm depth, a fragment of white ceramic plate with an embossed design from 150-cm depth, and a fragment of brown bottle glass with an embossed date of "1890" from 180-cm depth.

\section{BHT2}

UTM coordinates: Approximately $550300^{\mathrm{m}} \mathrm{E}, 3256200^{\mathrm{m}} \mathrm{N}$ (Zone $14 \mathrm{~N}$ ) (Geological Survey 1992).

Elevation: Approximately 198 m AMSL (Geological Survey 1992).

Trench dimensions: $660 \mathrm{~cm}$ long and $210 \mathrm{~cm}$ wide at ground level; $100 \mathrm{~cm}$ wide at depth; $260 \mathrm{~cm}$ deep.

Stratigraphy: Historical and modern fill, $260 \mathrm{~cm}$ exposed thickness, mostly silty sandy clay containing crushed limestone gravel, limestone and cut granite boulders, and cobble-size masses of clay. Fill appears to be vertically stratified in part. Sediment samples: None.

Artifacts: Many low-fired yellow bricks, few fragments of mostly brown-colored bottle glass, fragments of cinder blocks and concrete, metal straps, numerous unidentified modern metal objects and metal fragments, and many bone fragments. Recovered provenienced artifacts include two bone fragments (bovine ribs) from 153-cm depth.

Schiller Street locality: Two backhoe trenches (BHT3 and BHT4) were excavated on an undeveloped tract southeast and east of corner of Schiller Street and East Quincy Street, and one backhoe trench (BHT5) was excavated on an undeveloped tract southwest of southeastern end of East Myrtle Street, San Antonio, Bexar County, Texas. Geomorphic context: Right (northwestern) bank of river; "natural" (unrectified) channel reach; bank partly modified by filling; modified (filled and leveled) flood terrace, nearly level. Nominal soils: Trinity and Frio series (undivided). Vegetation: Dense to partly open riparian woodland, modified by urbanization, dominated by hackberry, pecan, sycamore, and live oak, with invasive nonnative woody species. Land use: Cultivated and probably irrigated historically (Cox 2005:19 map); contiguous construction of commercial buildings; ground has been leveled and river bank has been stabilized by repeated emplacement of exotic earthen fill and cultural debris.

\footnotetext{
*See Figure 4-8.
} 
Table A-1. Continued...

\section{BHT3}

UTM coordinates: Approximately 550240 $\mathrm{m}$, 3256820 $\mathrm{m}$ (Zone $14 \mathrm{~N}$ ) (Geological Survey 1992).

Elevation: Approximately 199 m AMSL (Geological Survey 1992).

Trench dimensions: $430 \mathrm{~cm}$ long and $200 \mathrm{~cm}$ wide at ground level; $95 \mathrm{~cm}$ wide at depth; $260 \mathrm{~cm}$ deep.

Stratigraphy: Historical and modern fill, $260 \mathrm{~cm}$ exposed thickness, mostly silty sandy clay containing crushed limestone gravel and cobble-size masses of clay. Fill appears to be vertically stratified in part.

Sediment samples: None.

Artifacts: Many low-fired yellow bricks, fragments of clear window glass and variously colored bottle glass, fragments of terracotta roofing tiles at $100-\mathrm{cm}$ depth, numerous unidentified metal objects of various sizes, and many pebble-size fragments of bituminous coal at $200-\mathrm{cm}$ depth. One provenienced artifact was recovered: a metallic spring-like object from $120-\mathrm{cm}$ depth.

\section{BHT4}

UTM coordinates: Approximately $550270^{\mathrm{m}} \mathrm{E}, 3256840^{\mathrm{m}} \mathrm{N}$ (Zone $14 \mathrm{~N}$ ) (Geological Survey 1992).

Elevation: Approximately 199 m AMSL (Geological Survey 1992).

Trench dimensions: $440 \mathrm{~cm}$ long and $220 \mathrm{~cm}$ wide at ground level; $120 \mathrm{~cm}$ wide at depth; $220 \mathrm{~cm}$ deep.

Stratigraphy: Historical and modern fill, $220 \mathrm{~cm}$ exposed thickness, mostly silty sandy clay containing crushed limestone gravel and cobble-size masses of clay. Fill appears to be vertically stratified in part.

Sediment samples: None.

Artifacts: Many conjoined low-fired yellow bricks set in mortar, brown ceramic rim sherd at 90-cm depth, brown ceramic sherd at $95-\mathrm{cm}$ depth, spoon with shell motif on handle at $95-\mathrm{cm}$ depth, and concrete slab at $40-\mathrm{cm}$ depth. No provenienced artifacts were recovered.

\section{BHT5}

UTM coordinates: Approximately 550260mE, 3256880m N (Zone 14 N) (Geological Survey 1992).

Elevation: Approximately 199 m AMSL (Geological Survey 1992).

Trench dimensions: not recorded; $30 \mathrm{~cm}$ deep. Trench abandoned because water pipe was found at 10-cm depth.

Stratigraphy: Modern fill, $30 \mathrm{~cm}$ exposed thickness, silty sandy clay.

Sediment samples: None.

Artifacts: Metal pipe. No provenienced artifacts were recovered.

Ninth Street locality: Three backhoe trenches (BHT6-8) were excavated on an undeveloped (cleared) tract northeast of the northwestern end of the Ninth Street bridge over San Antonio River, San Antonio, Bexar County, Texas. Geomorphic context: Right (northwestern) bank of river; rectified channel reach; bank partly modified by filling; modified (filled and leveled) flood terrace, nearly level. Nominal soils: Trinity and Frio series (undivided). Vegetation: Open riparian woodland, modified by urbanization, dominated by hackberry and live oak, with invasive non-native woody species. Land use: Former home site (cleared) and landfill; ground has been leveled and river bank has been stabilized by repeated emplacement of exotic earthen fill and cultural debris; cultivated and probably irrigated historically (Cox 2005:19 map).

\section{BHT6}

UTM coordinates: Approximately 550170m E, 3256190m N (Zone 14 N) (Geological Survey 1992).

Elevation: Approximately 199 m AMSL (Geological Survey 1992).

Trench dimensions: $470 \mathrm{~cm}$ long and $230 \mathrm{~cm}$ wide at ground level; $115 \mathrm{~cm}$ wide at depth; $240 \mathrm{~cm}$ deep.

Stratigraphy: Modern fill, $240 \mathrm{~cm}$ exposed thickness, mostly silty sandy clay containing crushed limestone gravel.

Sediment samples: None.

Artifacts: Many low-fired yellow bricks, fragments of concrete, and pieces of wire and iron pipe. No provenienced artifacts were recovered. 
Table A-1. Continued...

\section{BHT7}

UTM coordinates: Approximately 550160mE, 3256180m N (Zone $14 \mathrm{~N}$ ) (Geological Survey 1992).

Elevation: Approximately 199 m AMSL (Geological Survey 1992).

Trench dimensions: $250 \mathrm{~cm}$ long, $84 \mathrm{~cm}$ wide, and $15 \mathrm{~cm}$ deep. Trench abandoned because of uncertainty regarding property access.

Stratigraphy: Modern fill, $15 \mathrm{~cm}$ exposed thickness, mostly silty sandy clay containing crushed limestone gravel. Sediment samples: None.

Artifacts: Fragments of concrete. No provenienced artifacts were recovered.

\section{BHT8}

UTM coordinates: Approximately 550120mE, 3256150m N (Zone 14 N) (Geological Survey 1992).

Elevation: Approximately 199 m AMSL (Geological Survey 1992).

Trench dimensions: $550 \mathrm{~cm}$ long and $270 \mathrm{~cm}$ wide at ground level; $80 \mathrm{~cm}$ wide at depth; $245 \mathrm{~cm}$ deep.

Stratigraphy: Historical and modern clayey sandy gravel fill from 0 - to $65-\mathrm{cm}$ depth, overlying silty sandy clay floodterrace deposits from 65- to 245-cm exposed depth (see Table A-2).

Sediment samples: Five bulk sediment samples were collected as follows: S1, $43-49 \mathrm{~cm}$; S2, 67-78 cm; S3, 81-96 cm; S4, 128-150 cm; and S5, 180-200 cm. For results of sediment analyses, see Tables A-1 and A-2, Figure 4-9, and Appendices A and B).

Artifacts: Near-surface assemblage (approximately 0- to 30-cm depth) includes low-fired yellow bricks, fragments of clear window glass, and aluminum cans. Deeper assemblage (approximately 30- to 65-cm depth) includes numerous heavily corroded metal objects from 45- to 65-cm depth, bone fragment at 61-cm depth, iron pipe in situ at 65-cm depth, and a layer of pebble-size fragments of bituminous coal from 55- to $65-\mathrm{cm}$ depth. Recovered provenienced artifacts include nail from 55-cm depth, unidentified bone from 61-cm depth, and bituminous coal from 55- to 65-cm depth. 
Table A-2. Stratigraphic Profile Exposed in the Northern Wall of Backhoe Trench 8 (BHT8), Ninth Street Locality*

Location, geomorphic setting, and notes concerning profile description

- Proposed San Antonio River Improvements Project area, Museum Reach, San Antonio, central Bexar County, Texas; $25 \mathrm{~m}$ northeast of the northwestern end of Ninth Street bridge over San Antonio River; UTM coordinates are approximately $550120 \mathrm{mE}, 3256150 \mathrm{mN}$ (Zone $14 \mathrm{~N}$ ); elevation is approximately $199 \mathrm{~m}$ AMSL (Geological Survey 1992).

- West Gulf Coastal Plain physiographic region (Fenneman 1946); San Antonio River flood terrace; right (western) bank of the San Antonio River, approximately 10 m northwest of the channel (Geological Survey 1992).

- Nominal geology: Holocene "low terrace deposits above flood level" (Brown et al. 1983), indicating that the terrace is inactive; however, the terrace was actually flooded frequently prior to artificial channel modifications during the twentieth century, and is occasionally flooded even today; the flood terrace is underlain by moderately thick Late Pleistocene(?)/early to late Holocene flood-terrace (channel and overbank) and palustrine deposits; maximum depth of trench did not reach present water table.

- Nominal soils: Trinity and Frio series (undivided) (Taylor et al. 1962:16, 31-32, Sheet Number 54). The Trinity Series is a Typic Hapludert and the Frio is a Cumulic Haplustoll (Soil Survey Staff, 1997). The soil described below is similar to the typical Frio Series.

- Profile was described on 11 August, 2005, by S. C. Caran and C. A. Speer.

- Texture was characterized in the field in both geological and pedological terms, aided by $10 x$ magnification and use of grain-size comparator. Terms for pedological texture are shown in parentheses.

- Soil colors were determined in the field under ambient lighting and moisture conditions, using Munsell Soil Color Charts.

- Depths were measured relative to present ground level on the northern side of the trench.

\section{Profile Description}

Fill Stratum 1: 0 to $56-60 \mathrm{~cm}$, locally to $65 \mathrm{~cm}$; highly variegated, colors not determined; clayey sandy gravel, increasingly gravelly below 10 to $34 \mathrm{~cm}$ locally; gravel consists of mostly well-rounded limestone pebbles and calcareous concretions with cobble- to boulder-size fragments of concrete (fill); common fragments of window glass, brick, and metal objects throughout, with mostly pebble-size fragments of bituminous coal and rusted metal scattered throughout lower $10 \mathrm{~cm}$ and concentrated in 1 to $3 \mathrm{~cm}$ thick layer immediately overlying lower boundary; abrupt, wavy boundary, preserving possible plowed furrows with $84-116 \mathrm{~cm}$ wavelengths and 7-10 $\mathrm{cm}$ amplitudes. Historical landfill deposit. Collected: Bulk sediment sample 1 (S1) between 43 and $49 \mathrm{~cm}$ depth; nail at $55 \mathrm{~cm}$ depth, $280 \mathrm{~cm}$ west of eastern end of trench; bone at $61 \mathrm{~cm}$ depth, $265 \mathrm{~cm}$ west of eastern end of trench; and bituminous coal from 55 to $65 \mathrm{~cm}$ depth.

A Stratum 2: 56-60 (locally 56-65) to $105-116 \mathrm{~cm}$; very dark gray (10YR 3/1) varying to very dark grayish brown (10YR 3/2) below 80-94 cm depth; coloration above 80-94 cm depth appears to be related to organic contamination with landfill leachate and/or soot; very silty slightly sandy clay (silty clay); sand is very fine to fine and consists of limestone lithoclasts; strong to moderate (decreasing downward) medium to very coarse angular blocky structure; extremely hard, dry; moderately plastic and moderately sticky when wetted; common partly open extra-structural cracks (penetrant syneresis fractures, formerly surface connected) extending to $73 \mathrm{~cm}$ depth; peds along upper boundary exhibit localized conchoidal fractures possibly related to vehicle-induced compaction; few fine roots; few fine open pores; few whole land snail shells and coarse sand-size shell fragments; iron pipe subparallel to ground at $65 \mathrm{~cm}$ depth; gradual, wavy boundary. Late Holocene fluvial overbank deposit. Collected: Bulk sediment samples 2 (S2) between 67 and $78 \mathrm{~cm}$ depth and 3 (S3) between 81 and $96 \mathrm{~cm}$ depth. Sample S3: conventional radiocarbon age $2060 \pm 70, \delta^{13} \mathrm{C}$ $-18.8 \%$.

\footnotetext{
*See Figures 4-8, 4-9, and 4-10.
} 
Table A-2. Continued...

Bw Stratum 3: 105-116 to $176 \mathrm{~cm}$; dark grayish brown (10YR 4/2) varying to brown (10YR 4/3) below $147 \mathrm{~cm}$ depth; very silty slightly sandy clay (silty clay); sand is very fine to fine and consists of limestone lithoclasts; weak to moderate medium angular blocky structure; hard, dry; moderately plastic and moderately sticky when wetted; common calcareous filaments; incipient argillans (thin, incomplete); few fine roots; few fine open pores; few whole land snail shells and coarse sand-size shell fragments; gradual, wavy boundary. Late Holocene fluvial overbank deposit. Collected: Bulk sediment sample 4 (S4) between 128 and $150 \mathrm{~cm}$ depth. Sample S4: conventional radiocarbon age $2980 \pm 70, \delta^{13} \mathrm{C}$ $-19.7 \%$.

Bk Stratum 4: 176 to $245 \mathrm{~cm}$ (limit of exposure); brown (10YR 4/3) with many very pale brown (10YR 7/3) calcareous masses and concretions; very silty slightly sandy clay (silty clay); sand is very fine to fine and consists of limestone lithoclasts; weak fine angular blocky structure; hard, dry; moderately plastic and moderately sticky when wetted; many soft fine calcareous masses and concretions (rhyzoconcretions); incipient argillans (thin, incomplete); few fine roots; few fine open pores; few whole land snail shells and coarse sand-size shell fragments. Middle Holocene fluvial overbank/ palustrine deposit. Collected: Bulk sediment sample 5 (S5) between 180 and $200 \mathrm{~cm}$ depth. Sample S5: conventional radiocarbon age $3580 \pm 70, \delta^{13} \mathrm{C}-19.1 \%$. 


\title{
Appendix B
}

\section{Stratigraphic Profiles of Boreholes}

\author{
S. Christopher Caran and Charles A. Speer
}


Table B-1. Description of Selected Borehole Profiles, Proposed San Antonio River Improvement Project, Museum Reach*

From January through April, 2005, representatives of Arias and Associates, Inc., San Antonio, completed 63 boreholes (B-1 through B-30 and B-32 through B-64) within the Museum Reach of the Proposed San Antonio River Improvements Project corridor. Boreholes were drilled along both banks of the San Antonio River in San Antonio, Bexar County, Texas, in support of Arias' geotechnical engineering study (Bacon 2005). Arias personnel surveyed the project area, drilled the boreholes, collected and curated core samples, and subjected selected samples to destructive analyses of their geotechnical engineering properties. Based on the samples still available in September 2005, and on Arias' records, S. C. Caran described the stratigraphic profiles at 17 of the boreholes, emphasizing their genetic stratigraphy and related characteristics. These boreholes were located throughout the Museum Reach. Caran also collected a portion of the remaining cores from three of the boreholes, B-2, B-23, and B-63. A total of 10 samples was further divided into fractions that underwent separate radiocarbon/carbon stable-isotope and palynological analyses. Results of the radiocarbon/stable-isotope analyses of organic carbon are summarized here and disclosed in full in Table B-2. The palynological analyses were hampered by poor pollen preservation, but the findings are presented in Appendix C and discussed in Chapter 4.

Location, geomorphic setting, and notes concerning profile descriptions

- Location: Proposed San Antonio River Improvements Project area, Museum Reach, San Antonio, central Bexar County, Texas (see Figure 4-8).

- Geomorphic context: West Gulf Coastal Plain physiographic region (Fenneman 1946); San Antonio River flood terrace; right and left banks.

- Stratigraphy: Nominally Holocene "low terrace deposits above flood level" (Brown et al. 1983), indicating that the terrace is inactive; however, the terrace was actually flooded frequently prior to artificial channel modifications during the twentieth century, and is occasionally flooded even today. These floods deposited fine-grained, organicrich sediment across the terrace. The flood terrace is underlain by moderately thick Late Pleistocene/early to late Holocene flood-terrace (channel and overbank) and palustrine deposits, overlying weathered and relatively fresh Upper Cretaceous mudstones of the Marlbrook Formation (upper Taylor Group).

- Soils: Nominally the Trinity and Frio series (undivided) (Taylor et al. 1962:16, 31-32, Sheet Numbers 45 and 54). The Trinity Series is a Typic Hapludert and the Frio is a Cumulic Haplustoll (Soil Survey Staff 1997). Results of the present investigation generally corroborate the findings of Taylor and others (1962), although the stratigraphy is somewhat more complex.

- Some reaches of the river channel were modified (rectified) during the twentieth century and earlier by dredging new channel segments, generally across the necks of meander loops. Where recognizable, these rectified reaches are identified below.

- As reported by Bacon (2005), borehole locations are approximate (see Figure 4-8).

- Boreholes were numbered sequentially, from north to south.

- As reported below, ground-level elevations at each borehole location are based on data from Bacon (2005).

- Arias and Associates, Inc. recorded the depth range of each sample in feet below ground level. Those depth notations serve to identify the samples and are, therefore, reproduced here, along with their metric equivalents.

- S. C. Caran characterized the texture of each sample in sedimentological terms, aided by 10x magnification and use of a grain-size comparator. Caran also determined each sample's color under indoor lighting and ambient moisture conditions using Munsell Soil Color Charts. Pedogenic and sedimentary structures were evident in only a few samples, but these and other characteristics were described.

- Throughout the following discussion, descriptions are separated from interpretations regarding the age and origin of each stratum. Radiocarbon ages and carbon stable-isotope ratios are noted where available. Where no radiocarbon chronology was obtained, ages are inferred from the geomorphic setting, genetic stratigraphy, type and degree of soil development, depth of burial, proximity to the subjacent bedrock, and analogy to the radiocarbon record for Boreholes 2, 23, and 63 and Backhoe Trench 8. In the absence of more definitive criteria, these age estimates must be regarded as tentative.

\footnotetext{
*See Figures 4-8 and 4-10.
} 
Table B-1. Continued...

\section{Borehole B-1}

Northeast of Grayson Street, right (western) bank, natural (unrectified) reach, $200.5 \mathrm{~m}$ AMSL.

0-2 ft. (0-0.6 m): Gravel-size caliche fragments; color not determined; soft; dry. Modern/historical earthen fill.

2-3 ft. (0.6-0.9 m): Silty clay, admixed with gravel-size caliche fragments; fine-grained matrix is brown (10YR 5/3); soft; dry; common granule-size charcoal fragments. Compacted late Holocene overbank deposit with modern soil and intrusive modern/historical earthen fill.

3-4 ft. (0.9-1.2 m): Very silty sandy slightly gravelly clay, admixed with granule-size fragments of caliche; sand is very fine; gravel consists of rounded limestone granules; very dark gray (10YR 3/1); soft; dry. Compacted late Holocene channelmargin deposit with modern to late Holocene soil and intrusive modern/historical earthen fill.

4-6 ft. (1.2-1.8 m): Very silty sandy clay, admixed with caliche and rounded limestone granules; sand is very fine; very dark gray (10YR 3/1), locally with fine brown (10YR 5/3) mottles; moderate fine angular blocky structure; friable; slightly moist; few very coarse sand-size fragments of land-snail shells. Late Holocene overbank deposit with late Holocene soil and intrusive modern/historical earthen fill.

6-8 ft. (1.8-2.4 m): Very small sample; limestone pebbles, apparently in a matrix of very silty sandy clay; sand is very fine; fine-grained matrix is very dark gray (10YR 3/1); friable; slightly moist. Late Holocene chute-channel deposit and/or overbank deposit with intrusive modern/historical earthen fill(?).

8-10 ft. (2.4-3.0 m): Very silty clay; grayish brown (10YR 5/2); friable; slightly moist; many calcareous filaments and soft granule- to pebble-size calcareous masses. Late Holocene overbank deposit with late Holocene soil.

10-12 ft. (3.0-3.7 m): Very silty gravelly clay; gravel consists of limestone pebbles; grayish brown (10YR 5/2); friable; slightly moist; few calcareous filaments and soft granule- to pebble-size calcareous masses. Middle(?) Holocene channel deposit with middle(?) Holocene buried soil.

12-14 ft. (3.7-4.3 m): No sample.

14-16 ft. (4.3-4.9 m): Very small sample; very silty very gravelly clay; gravel consists of rounded limestone granules and pebbles; grayish brown (10YR 5/2); friable; slightly moist; few calcareous filaments and soft granule- to pebble-size calcareous masses. Early to middle(?) Holocene channel deposit with middle(?) Holocene buried soil.

$16-18 \mathrm{ft} .(4.9-5.5 \mathrm{~m})$ : No sample.

18-20 ft. (5.5-6.1 m): Slightly silty clay; yellowish brown (10YR 5/4) oxidizing to yellowish brown (10YR 5/6); friable; slightly moist. Weathered bedrock (Upper Cretaceous Marlbrook Formation).

20-23 ft. (6.1-7.0 m): No sample.

23-25 ft. (7.0-7.6 m): Mudstone; brown (10YR 5/3) oxidizing to yellowish brown (10YR 5/6); hard; dry; many granulesize gypsum laths and sand-size gypsum crystals (efflorescence). Bedrock (Upper Cretaceous Marlbrook Formation).

25-28 ft. (7.6-8.5 m): No sample.

28-30 ft. (8.5-9.1 m): Mudstone; gray (10YR 6/1) oxidizing to yellowish brown (10YR 5/6); hard; dry; few granule-size fragments of fossil marine mollusk shells. Bedrock (Upper Cretaceous Marlbrook Formation).

30-33 ft. (9.1-10.1 m): No sample.

33-35 ft. (10.1-10.7 m): Mudstone; gray (10YR 5/1); unoxidized; hard; dry; few granule-size fragments of fossil marine mollusk shells. Bedrock (Upper Cretaceous Marlbrook Formation).

35-38 ft. (10.7-11.6 m): No sample.

38-40 ft. (11.6-12.2 m): Mudstone; gray (10YR 5/1); unoxidized; hard; dry; few granule-size fragments of fossil marine mollusk shells. Bedrock (Upper Cretaceous Marlbrook Formation).

\section{Borehole B-2}

Northeast of Grayson Street, left (eastern) bank, natural (unrectified) reach, $200.7 \mathrm{~m}$ AMSL.

0-2 ft. (0-0.6 m): Small sample; angular pebble-size fragments of crushed limestone; color not determined; loose; dry. Modern earthen fill.

2-4 ft. (0.6-1.2 m): Small sample; very silty sandy gravelly clay; sand is very fine to fine; gravel consists of rounded limestone granules; very dark gray (10YR 3/1); loose; dry. Late Holocene overbank deposit with modern soil and intrusive modern/historical earthen fill. 
Table B-1. Continued...

4-6 ft. (1.2-1.8 m): Silty clay, admixed with gravel-size caliche fragments (possible down-hole contaminant?); soil matrix is brown (10YR 5/3); soft; dry; common granule-size charcoal fragments. Late Holocene overbank deposit with modern soil and intrusive modern/historical earthen fill.

6-8 ft. (1.8-2.4 m): Very silty sandy slightly gravelly clay; sand is very fine to fine; gravel consists of rounded limestone granules; dark gray to dark grayish brown (10YR 4/1.5); friable; slightly moist; common sand-size fragments of land-snail shells. Late Holocene channel-margin deposit with late Holocene soil. Sample S1: Conventional radiocarbon age, $1580 \pm$ $70 \mathrm{BP} ; \delta^{13} \mathrm{C},-20.7 \%$.

8-10 ft. (2.4-3.0 m): Very silty sandy gravelly clay; sand is very fine to fine; gravel consists of rounded limestone granules and pebbles; dark grayish brown (10YR 4/2); friable; slightly moist; common sand-size fragments of land-snail shells; few pebble-size spherical insect burrows filled with fine casts. Late Holocene channel-margin deposit with late Holocene soil. Sample S2: Conventional radiocarbon age, $2310 \pm 70 \mathrm{BP} ; \delta^{13} \mathrm{C},-21.1 \%$.

$10-12 \mathrm{ft} .(3.0-3.7 \mathrm{~m})$ : Very silty sandy gravelly clay; sand is very fine to fine; gravel consists of rounded limestone granules and pebbles; dark grayish brown (10YR 4/2); friable; slightly moist; common sand-size fragments of land-snail shells. Late Holocene channel deposit with late Holocene soil. Sample S3: Conventional radiocarbon age, $2360 \pm 70 \mathrm{BP} ; \delta^{13} \mathrm{C},-22.1 \%$. 12-14 ft. (3.7-4.3 m): No sample.

14-16 ft. (4.3-4.9 m): Very small sample; very silty sandy gravelly clay; sand is very fine to fine; gravel consists of rounded limestone granules and pebbles; dark grayish brown (10YR 4/2); friable; slightly moist; common sand-size fragments of land snail shells. Early(?) to middle Holocene channel deposit with early(?) to middle Holocene soil.

$16-18 \mathrm{ft} .(4.9-5.5 \mathrm{~m})$ : No sample.

$18-20 \mathrm{ft}$. (5.5-6.1 m): Very small sample; very clayey very silty sandy gravel; sand is very fine to fine; gravel consists of limestone pebbles; dark grayish brown (10YR 4/2); friable; slightly moist. Early Holocene channel deposit with early Holocene soil.

20-23 ft. (6.1-7.0 m): No sample.

23-25 ft. (7.0-7.6 m): Very gravelly slightly silty clay; gravel consists of limestone pebbles; yellowish brown (10YR 5/4) oxidizing to yellowish brown (10YR 5/6); friable; slightly moist. Late Pleistocene or early Holocene(?) channel deposit with locally derived weathered bedrock (Upper Cretaceous Marlbrook Formation).

$25-28 \mathrm{ft}$. (7.6-8.5 m): No sample.

28-30 ft. (8.5-9.1 m): Mudstone; gray (10YR 6/1) oxidizing to yellowish brown (10YR 5/6); hard; dry; few granule-size fragments of fossil marine mollusk shells. Bedrock (Upper Cretaceous Marlbrook Formation).

30-33 ft. (9.1-10.1 m): No sample.

33-35 ft. (10.1-10.7 m): Mudstone; gray (10YR 5/1); unoxidized; hard; dry; few granule-size fragments of fossil marine mollusk shells. Bedrock (Upper Cretaceous Marlbrook Formation).

$35-38 \mathrm{ft} .(10.7-11.6 \mathrm{~m})$ : No sample.

38-40 ft. (11.6-12.2 m): Mudstone; gray (10YR 5/1); unoxidized; hard; dry; few granule-size fragments of fossil marine mollusk shells. Bedrock (Upper Cretaceous Marlbrook Formation).

\section{Borehole B-4}

Southwest of Grayson Street, right (western) bank, natural (unrectified) reach, $200.1 \mathrm{~m}$ AMSL.

$0-2 \mathrm{ft} .(0-0.6 \mathrm{~m})$ : Very silty gravelly sandy clay, admixed with caliche gravel; sand is very fine to fine; gravel consists of rounded limestone granules and pebbles and pebble-size fragments of caliche; grayish brown (10YR 5/2); very hard; dry. Compacted late Holocene overbank deposit with modern soil and intrusive modern/historical earthen fill.

$2-4 \mathrm{ft}$. (0.6-1.2 m): Very silty sandy clay; sand is very fine to fine; grayish brown (10YR 5/2) to brown (10YR 5/3); very firm; slightly moist; few soft pebble-size calcareous masses; common calcareous filaments; common very coarse sand- to granule-size fragments of land snail shells. Late Holocene overbank deposit with late Holocene soil.

4-6 ft. (1.2-1.8 m): Very silty sandy clay; sand is very fine to fine; grayish brown (10YR 5/2) to brown (10YR 5/3); very firm; slightly moist; few soft pebble-size calcareous masses; common calcareous filaments; common very coarse sand- to granule-size fragments of land snail shells. Late Holocene overbank deposit with late Holocene soil. 
Table B-1. Continued...

6-8 ft. (1.8-2.4 m): Very silty sandy clay; sand is very fine to fine; grayish brown (10YR 5/2) to brown (10YR 5/3); very firm; slightly moist; common calcareous filaments; common very coarse sand- to granule-size fragments of land snail shells. Late Holocene overbank deposit with late Holocene soil.

$8-10 \mathrm{ft}$. (2.4-3.0 m): Very silty sandy slightly gravelly clay; sand is very fine to fine; gravel consists of limestone granules and pebbles; grayish brown (10YR 5/2) with few faint yellowish brown (10YR 5/4) mottles and few very dark gray (10YR 3/1) fine to medium clay-filled root conduits; very firm; moist. Middle(?) to late Holocene channel-margin deposit with middle(?) to late Holocene soil.

$10-12 \mathrm{ft}$. (3.0-3.7 m): Very silty sandy slightly gravelly to locally gravelly clay; sand is very fine to fine; gravel consists of limestone granules and pebbles; grayish brown (10YR 5/2) with few faint yellowish brown (10YR 5/4) mottles and few very dark gray (10YR 3/1) fine to medium clay-filled root conduits; very firm; moist. Middle(?) Holocene channel deposit with middle(?) to late Holocene soil.

$12-14 \mathrm{ft} .(3.7-4.3 \mathrm{~m})$ : No sample.

14-16 ft. (4.3-4.9 m): Very silty sandy clay; sand is very fine to fine; grayish brown (10YR 5/2) with few faint yellowish brown (10YR 5/4) mottles and few very dark gray (10YR 3/1) fine to medium clay-filled root conduits; very firm; moist. Early(?) to middle Holocene channel-margin deposit with early(?) to middle Holocene soil.

$16-18 \mathrm{ft}$. (4.9-5.5 m): No sample.

$18-20 \mathrm{ft}$. (5.5-6.1 m): Very clayey very silty sandy gravel; sand is very fine to fine; gravel consists of limestone and chert granules and pebbles; light brownish gray (10YR 6/2) with few very dark gray (10YR 3/1) fine to medium clay-filled root conduits; very firm; moist. Late Pleistocene to early Holocene(?) channel deposit with Late Pleistocene to early Holocene(?) soil.

20-23 ft. (6.1-7.0 m): No sample.

$23-25$ ft. (7.0-7.6 m): Laminated mudstone; yellowish brown (10YR 5/4) with few gray (10YR 5/1) medium reduction mottles; friable; moist. Slightly weathered bedrock (Upper Cretaceous Marlbrook Formation).

$25-28 \mathrm{ft}$. (7.6-8.5 m): No sample.

28-30 ft. (8.5-9.1 m): Mudstone; dark gray (10YR 4/1); hard; dry. Bedrock (Upper Cretaceous Marlbrook Formation).

\section{Borehole B-5}

Southwest of Grayson Street, left (eastern) bank, rectified reach, $196.3 \mathrm{~m}$ AMSL.

0-2 ft. (0-0.6 m): Gravelly silty clay, admixed with pebble-size angular fragments of crushed limestone; gravel consists of rounded limestone pebbles; dark gray (10YR 4/1) with few fine light yellowish brown (10YR 6/4) mottles; friable; slightly moist; moderately organic-rich. Modern overbank deposit with modern soil and intrusive modern earthen fill.

2-4 ft. (0.6-1.2 m): Silty clay, admixed with clayey gravelly sand; sand is very fine to medium; gravel consists of limestone granules and pebbles; dark gray (10YR 4/1) with few fine light yellowish brown (10YR 6/4) mottles; friable; slightly moist. Late Holocene overbank deposit with modern soil and intrusive modern/historical earthen fill.

4-6 ft. (1.2-1.8 m): Silty clay; dark gray (10YR 4/1) to light brownish gray (10YR 6/2); friable; slightly moist; few to many soft pebble-size irregular calcareous masses. Late Holocene overbank deposit with late Holocene soil.

6-8 ft. (1.8-2.4 m): Silty clay; light brownish gray (10YR 6/2); friable; slightly moist; many hard granule- to pebble-size calcareous nodules. Late Holocene overbank deposit with late Holocene soil.

8-10 ft. (2.4-3.0 m): Small sample; very silty clay; light gray (10YR 7/1) to white (10YR 8/1); hard; dry; highly calcareous; modified by testing? Middle(?) Holocene overbank deposit with middle(?) Holocene soil.

10-12 ft. (3.0-3.7 m): Small sample; very silty clay; light gray (10YR 7/1) to white (10YR 8/1); hard; dry; highly calcareous; modified by testing(?). Early(?) to middle Holocene overbank deposit with early(?) to middle Holocene soil.

$12-14 \mathrm{ft} .(3.7-4.3 \mathrm{~m})$ : No sample.

14-16 ft. (4.3-4.9 m): Very small sample; very sandy clay; sand is very fine to fine; brown (10YR 4/3); friable; slightly moist. Early(?) Holocene overbank deposit with early(?) Holocene soil.

$16-18 \mathrm{ft} .(4.9-5.5 \mathrm{~m})$ : No sample.

18-20 ft. (5.5-6.1 m): Very small sample; calcareous mudstone; dark grayish brown (10YR 4/2); laminated; hard; dry. Bedrock (Upper Cretaceous Marlbrook Formation). 
Table B-1. Continued...

20-23 ft. (6.1-7.0 m): No sample.

23-25 ft. (7.0-7.6 m): Very small sample; mudstone; grayish brown (10YR 5/2); laminated; hard; dry. Bedrock (Upper Cretaceous Marlbrook Formation).

$25-28 \mathrm{ft}$. (7.6-8.5 m): No sample.

28-30 ft. (8.5-9.1 m): Small sample; mudstone; dark gray (10YR 4/1) with light gray (10YR 7/1) reduction zones along root traces; very friable; moist. Bedrock (Upper Cretaceous Marlbrook Formation).

$30-33 \mathrm{ft} .(9.1-10.1 \mathrm{~m})$ : No sample.

33-35 ft. (10.1-10.7 m): Small sample; mudstone; dark gray (10YR 4/1); very friable; moist; few soft granule- to pebblesize calcareous masses. Bedrock (Upper Cretaceous Marlbrook Formation).

35-38 ft. (10.7-11.6 m): No sample.

38-40 ft. (11.6-12.2 m): Small sample; mudstone; dark gray (10YR 4/1); very friable; moist; few soft granule- to pebblesize calcareous masses; small fossil marine bivalve (scallop). Bedrock (Upper Cretaceous Marlbrook Formation).

\section{Borehole B-8}

Southeast of the southeastern end of East Myrtle Street, left (eastern) bank, natural (unrectified) reach, $199.1 \mathrm{~m}$ AMSL. $0-2 \mathrm{ft}$. (0-0.6 m): Very small sample; sandy gravelly clay; gravel consists of rounded limestone pebbles; dark gray (10YR 4/1); friable; slightly moist. Modern overbank deposit(?) with modern soil and intrusive modern earthen fill.

2-10 ft. (0.6-3.0 m): No samples. This interval reportedly includes: dark gray brown clay fill, 2-4 ft. (0.6-1.2 m); black sandy slightly gravelly clay fill, 4-7 ft. (1.2-2.1 m); and black clay fill, 7-10 ft. (2.1-3.0 m) (Bacon 2005, Boring Log No. B-8).

$10-12 \mathrm{ft}$. (3.0-3.7 m): Very small sample; very sandy very silty slightly gravelly clay; sand is very fine to fine; gravel consists of rounded chert granules; black (10YR 2/1); friable; slightly moist. Middle(?) Holocene channel-margin deposit with middle(?) to late Holocene soil.

$12-14 \mathrm{ft} .(3.7-4.3 \mathrm{~m})$ : No sample.

14-16 ft. (4.3-4.9 m): Very small sample; silty clay; light gray (10YR 7/1); very friable; moist; few soft granule- to pebblesize calcareous nodules. Early(?) Holocene overbank deposit with early(?) Holocene soil.

$16-18 \mathrm{ft} .(4.9-5.5 \mathrm{~m})$ : No sample.

18-20 ft. (5.5-6.1 m): Very small sample; mudstone; yellowish brown (10YR 5/4); friable; moist. Weathered bedrock (Upper Cretaceous Marlbrook Formation).

20-40 ft. (6.1-12.2 m): No samples. This interval reportedly includes: gray and tan sandy clay (weathered bedrock), 20-25 ft. (6.1-7.6 m); and bluish gray claystone (bedrock), 25-40 ft. (7.6-12.2 m) (Bacon 2005, Boring Log No. B-8).

\section{Borehole B-9}

Northeast of Newell Street, left (eastern) bank, natural (unrectified) reach, $196.5 \mathrm{~m}$ AMSL.

$0-2 \mathrm{ft} .(0-0.6 \mathrm{~m})$ : Silty slightly gravelly clay; gravel consists of rounded limestone granules; black (10YR 2/1); friable; slightly moist; few fragments of wood. Modern overbank deposit with modern soil and intrusive modern earthen fill. 2-4 ft. (0.6-1.2 m): Sandy silty clay; sand is medium to very coarse; dark gray (10YR 4/1); friable; slightly moist; few very coarse sand-size fragments of charcoal and land snail shell. Modern/late Holocene overbank deposit with modern soil and intrusive modern/historical earthen fill.

4-6 ft. (1.2-1.8 m): Silty clay; dark gray (10YR 4/1); very friable; moist. Late Holocene overbank deposit with late Holocene soil.

6-10 ft. (1.8-3.0 m): No samples. This interval reportedly includes: dark gray brown sandy slightly gravelly clay, slightly organic, 6-10 ft. (1.8-3.0 m) (Bacon 2005, Boring Log No. B-9).

10-12 ft. (3.0-3.7 m): Small sample; silty clay; yellowish brown (10YR 5/4) to light gray (10YR 7/1); friable; moist. Middle(?) Holocene overbank deposit or deeply weathered bedrock with middle(?) to late Holocene soil.

$12-13 \mathrm{ft}$. (3.7-4.0 m): No sample.

13-15 ft. (4.0-4.6 m): Very small sample; silty clay; brown (10YR 4/3); friable; slightly moist. Early(?) to middle Holocene overbank deposit or deeply weathered bedrock with early(?) to middle Holocene soil. 
Table B-1. Continued...

15-23 ft. (4.6-7.0 m): No samples. This interval reportedly includes: tan and gray slightly sandy clay, 15-23 ft. (4.6-7.0 m) (Bacon 2005, Boring Log No. B-9).

23-25 ft. (7.0-7.6 m): Very small sample; mudstone; brown (10YR 5/3); hard; dry; fine sand-size calcite crystals filling fine root conduits. Weathered bedrock(?) (Upper Cretaceous Marlbrook Formation).

$25-28 \mathrm{ft} .(7.6-8.5 \mathrm{~m})$ : No sample.

28-30 ft. (8.5-9.1 m): Small sample; mudstone; dark gray (10YR 4/1); hard; dry. Bedrock (Upper Cretaceous Marlbrook Formation).

30-33 ft. $(9.1-10.1 \mathrm{~m})$ : No sample.

33-35 ft. (10.1-10.7 m): Small sample; mudstone; dark gray (10YR 4/1); hard; dry; few soft pebble-size irregular calcic zones. Bedrock (Upper Cretaceous Marlbrook Formation).

$35-38 \mathrm{ft}$. (10.7-11.6 m): No sample.

38-40 ft. (11.6-12.2 m): Small sample; mudstone; gray (10YR 5/1) with few fine black (10YR 2/1) stains along root conduits; hard; dry; few fine root conduits lines with calcareous efflorescence. Bedrock (Upper Cretaceous Marlbrook Formation).

\section{Borehole B-13}

South of Camden Street, left (eastern) bank, natural (unrectified) reach, $196.3 \mathrm{~m}$ AMSL.

$0-2 \mathrm{ft}$. (0-0.6 m): Very small sample; sandy gravelly clay; sand is very fine to fine; gravel consists of rounded limestone pebbles; gray (10YR 5/1); friable; slightly moist. Modern overbank deposit with modern soil and intrusive modern earthen fill.

$2-4$ ft. $(0.6-1.2 \mathrm{~m})$ : No sample.

4-6 ft. (1.2-1.8 m): Very small sample; clay; dark gray (10YR 4/1); friable; slightly moist; few calcareous filaments. Late Holocene overbank deposit with late Holocene soil.

$6-18 \mathrm{ft}$. (1.8-5.5 m): No samples. This interval reportedly includes: dark gray brown slightly sandy clay, $6-8 \mathrm{ft}$. (1.8-2.4 $\mathrm{m})$; gray brown clayey sandy gravel, $8-12 \mathrm{ft} .(2.4-3.7 \mathrm{~m})$; and tan and gray slightly sandy clay, $12-18 \mathrm{ft}$. $(3.7-5.5 \mathrm{~m})$ (Bacon 2005, Boring Log No. B-13).

18-20 ft. (5.5-6.1 m): Small sample; silty clay; yellowish brown (10YR 5/4); very friable; moist. Weathered bedrock(?) (Upper Cretaceous Marlbrook Formation).

20-23 ft. (6.1-7.0 m): No sample.

23-25 ft. (7.0-7.6 m): Very small sample; silty clay; yellowish brown (10YR 5/4); very friable; moist. Weathered bedrock(?) (Upper Cretaceous Marlbrook Formation).

$25-28 \mathrm{ft}$. (7.6-8.5 m): No sample.

28-30 ft. (8.5-9.1 m): Small sample; silty clay; brown (10YR 4/3); very friable; moist; fine to medium sand-size calcite crystals. Weathered bedrock (Upper Cretaceous Marlbrook Formation).

30-33 ft. (9.1-10.1 m): No sample.

33-35 ft. (10.1-10.7 m): Small sample; mudstone; pale brown (10YR 6/3); very hard; dry. Bedrock (Upper Cretaceous Marlbrook Formation).

$35-38 \mathrm{ft}$. (10.7-11.6 m): No sample.

38-40 ft. (11.6-12.2 m): Small sample; mudstone; pale brown (10YR 6/3) with few granule- to pebble-size light gray (10YR 7/1) reduction zones; few very coarse sand-size cavities lines with calcareous films; very hard; dry. Bedrock (Upper Cretaceous Marlbrook Formation).

\section{Borehole B-19}

Northwest of the northwestern end of Roy Smith Street, right (western) bank, natural (unrectified) reach, $199.0 \mathrm{~m}$ AMSL. $0-2 \mathrm{ft} .(0-0.6 \mathrm{~m})$ : Silty sandy clay, admixed with rounded limestone pebbles and pebble-size fragments of charcoal; sand is very fine to fine; very dark gray (10YR 3/1) to black (10YR 2/1); loose; dry; oil stained. Modern overbank deposit with modern soil and intrusive modern earthen fill. 
Table B-1. Continued...

2-4 ft. (0.6-1.2 m): Silty sandy clay, admixed with rounded limestone pebbles and pebble-size fragments of charcoal; sand is very fine to fine; very dark gray (10YR 3/1) to black (10YR 2/1); loose; dry; oil stained. Modern overbank deposit with modern soil and intrusive modern earthen fill.

4-5 ft. (1.2-1.5 m): Silty clay; dark gray (10YR 4/1) and very pale brown (10YR 8/4); loose; dry; many glass fragments. Modern overbank deposit with modern soil and intrusive modern earthen fill.

5-6 ft. (1.5-1.8 m): Slightly silty clay; very dark gray (10YR 3/1); friable; slightly moist. Modern overbank deposit with modern soil and intrusive modern earthen fill.

6-8 ft. (1.8-2.4 m): Silty clay; very dark gray (10YR 3/1); friable; slightly moist. Late Holocene overbank deposit with late Holocene soil.

8-10 ft. (2.4-3.0 m): Silty clay; dark gray (10YR 4/1); friable; slightly moist; many soft granule-size coarsely crystalline calcareous masses. Middle(?) to late Holocene overbank deposit with middle(?) to late Holocene soil.

10-12 ft. (3.0-3.7 m): Silty clay; dark gray (10YR 4/1); friable; slightly moist; many soft granule-size coarsely crystalline calcareous masses. Middle(?) Holocene overbank deposit with middle(?) Holocene soil.

$12-14 \mathrm{ft} .(3.7-4.3 \mathrm{~m})$ : No sample.

14-16 ft. (4.3-4.9 m): Silty clay; dark gray (10YR 4/1); friable; slightly moist; many soft pebble-size coarsely crystalline calcareous masses. Early(?) to middle Holocene overbank deposit with early(?) to middle Holocene soil.

$16-18 \mathrm{ft} .(4.9-5.5 \mathrm{~m})$ : No sample.

$18-20 \mathrm{ft}$. (5.5-6.1 m): Very clayey very silty sand; sand is very fine to fine; gray (10YR 6/1); very friable; moist; many soft granule-size calcareous masses. Early Holocene channel-margin deposit with early Holocene soil.

20-23 ft. $(6.1-7.0 \mathrm{~m})$ : No sample.

$23-25 \mathrm{ft}$. (7.0-7.6 m): Very clayey very silty sand; sand is very fine to fine; gray (10YR 6/1); very friable; very moist; highly calcareous with many soft granule-size calcareous masses. Late Pleistocene channel-margin deposit with Late Pleistocene Holocene soil.

25-28 ft. (7.6-8.5 m): No sample.

28-30 ft. (8.5-9.1 m): Silty clay; brown (10YR 5/3) with common fine gray (10YR 5/1) root mottles; very firm; moist. Weathered bedrock (Upper Cretaceous Marlbrook Formation).

30-33 ft. (9.1-10.1 m): No sample.

33-35 ft. (10.1-10.7 m): Silty clay; yellowish brown (10YR 5/4) with common fine to locally very coarse gray (10YR 5/1) mottles; very firm; moist. Weathered bedrock (Upper Cretaceous Marlbrook Formation).

$35-38 \mathrm{ft} .(10.7-11.6 \mathrm{~m})$ : No sample.

38-39 ft. (11.6-11.9 m): Silty clay; yellowish brown (10YR 5/4) with common very coarse gray (10YR 5/1) mottles; very firm; moist; few granule- to pebble-size soft calcareous masses. Weathered bedrock (Upper Cretaceous Marlbrook Formation). 39-40 ft. (11.6-12.2 m): Mudstone; dark gray (10YR 4/1) with many medium irregular brown (10YR 6/3) mottles; laminated; hard; dry. Weathered bedrock (Upper Cretaceous Marlbrook Formation).

$40-43 \mathrm{ft} .(12.2-13.1 \mathrm{~m})$ : No sample.

43-45 ft. (13.1-13.7 m): Very small sample; mudstone; gray (10YR 6/1); laminated; hard; dry. Bedrock (Upper Cretaceous Marlbrook Formation).

$45-48 \mathrm{ft} .(13.7-14.6 \mathrm{~m})$ : No sample.

48-50 ft. (14.6-15.2 m): Mudstone; dark gray (10YR 4/1); laminated; hard; dry. Bedrock (Upper Cretaceous Marlbrook Formation).

$50-53 \mathrm{ft} .(15.2-16.2 \mathrm{~m})$ : No sample.

53-55 ft. (16.2-16.8 m): Mudstone; dark gray (10YR 4/1); laminated; hard; dry; few soft very coarse sand-size calcareous masses. Bedrock (Upper Cretaceous Marlbrook Formation).

$55-58 \mathrm{ft}$. (16.8-17.7 m): No sample.

58-60 ft. (17.7-18.3 m): Mudstone; gray (10YR 5/1); laminated; extremely hard; dry; few soft very coarse sand-size calcareous masses. Bedrock (Upper Cretaceous Marlbrook Formation). 
Table B-1. Continued...

\section{Borehole B-23}

South of Roy Smith Street, left (eastern) bank, natural (unrectified) reach, $198.9 \mathrm{~m}$ AMSL.

$0-2 \mathrm{ft}$. (0-0.6 m): Silty sandy clay; sand is very fine to fine; black (10YR 2/1); loose; dry. Modern overbank deposit with modern soil and intrusive modern earthen fill.

2-3.5 ft. (0.6-1.1 m): Clay, admixed with degraded rounded limestone granules and pebbles; gray (10YR 5/1); loose; dry. Modern overbank deposit with modern soil and intrusive modern earthen fill.

3.5-4 ft. (1.1-1.2 m): Clay, admixed with sand and rounded limestone granules; sand is very fine to fine; gray (10YR 5/1); dense (compacted); dry. Modern overbank deposit with modern soil and intrusive modern earthen fill.

4-6 ft. (1.2-1.8 m): Sandy silty clay; sand is very fine to fine; gray (10YR 5/1); dense (compacted); moist; plastic. Modern overbank deposit with modern soil and intrusive modern earthen fill.

6-8 ft. (1.8-2.4 m): Sandy silty clay, admixed with granule-size fragments of charcoal; sand is very fine to fine; gray (10YR 5/1); friable; moist; plastic; few calcareous filaments; few sand-size snail shell fragments. Late Holocene overbank deposit with late Holocene soil and intrusive modern earthen fill. Sample S1: Conventional radiocarbon age, $1630 \pm 70 \mathrm{BP} ; \delta^{13} \mathrm{C}$, $-19.0 \%$.

8-10 ft. (2.4-3.0 m): Very sandy silty slightly gravelly clay; sand is very fine to fine; gravel consists of rounded limestone granules and pebbles; gray (10YR 5/1); friable; moist; plastic; few calcareous filaments; few sand-size snail shell fragments. Late Holocene channel-margin deposit with late Holocene soil.

10-12 ft. (3.0-3.7 m): Very silty slightly gravelly clay; gravel consists of rounded limestone pebbles; light gray (10YR 7/1); friable; slightly moist. Late Holocene channel-margin deposit with late Holocene soil. Sample S2: Conventional radiocarbon age, $2140 \pm 70 \mathrm{BP} ; \delta^{13} \mathrm{C},-21.2 \%$.

12-14 ft. (3.7-4.3 m): No sample.

14-16 ft. (4.3-4.9 m): Very clayey very sandy gravel; sand is very fine to fine; gravel consists of rounded limestone granules and pebbles; light gray (10YR 7/1); very friable; moist. Middle(?) or early Holocene channel deposit with middle(?) or early Holocene soil.

$16-18 \mathrm{ft}$. (4.9-5.5 m): No sample.

18-20 ft. (5.5-6.1 m): Slightly gravelly clay; gravel consists of rounded limestone pebbles; light gray (10YR 7/1) to light yellowish brown (10YR 6/4); friable; slightly moist. Late Pleistocene(?) or early Holocene channel-margin deposit with Late Pleistocene(?) or early Holocene soil.

20-23 ft. $(6.1-7.0 \mathrm{~m})$ : No sample.

$23-25 \mathrm{ft}$. (7.0-7.6 m): Slightly sandy clay; sand is coarse to very coarse; light yellowish brown (10YR 6/4) with light gray (10YR 7/1); very friable; very moist. Late Pleistocene channel-margin deposit with Late Pleistocene soil overlying weathered bedrock (Upper Cretaceous Marlbrook Formation). Sample S3: Conventional radiocarbon age, 18,070 \pm 560 BP; $\delta^{13} \mathrm{C}$, $-29.0 \%$.

25-28 ft. (7.6-8.5 m): No sample.

28-30 ft. (8.5-9.1 m): Silty clay; light yellowish brown (10YR 6/4) with fine light gray (10YR 7/1) reduction zones along root conduits; very firm; moist. Weathered bedrock (Upper Cretaceous Marlbrook Formation).

30-33 ft. (9.1-10.1 m): No sample.

33-35 ft. (10.1-10.7 m): Clay; light yellowish brown (10YR 6/4); very firm; moist; faint relict lamination. Weathered bedrock (Upper Cretaceous Marlbrook Formation).

$35-38$ ft. (10.7-11.6 m): No sample.

38-40 ft. (11.6-12.2 m): Mudstone; light yellowish brown (10YR 6/4) with fine light gray (10YR 7/1) reduction zones along root conduits; laminated; hard; dry. Weathered bedrock (Upper Cretaceous Marlbrook Formation). 
Table B-1. Continued...

\section{Borehole B-25}

West of the intersection of Avenue A and Twelfth Street, left (northeastern) bank, natural (unrectified) reach, $197.0 \mathrm{~m}$ AMSL. 0-2 ft. (0-0.6 m): Very silty sandy clay; sand is very fine to medium; very dark gray (10YR 3/1); loose; dry; possibly contaminated with motor oil or other organic liquid. Modern overbank or channel-margin deposit with modern soil and intrusive modern earthen fill.

2-4 ft. (0.6-1.2 m): Silty clay, admixed with granule-size angular limestone fragments and pebble-size charcoal fragments; dark gray (10YR 4/1); loose; dry. Modern overbank deposit with modern soil and intrusive modern earthen fill.

4-6 ft. (1.2-1.8 m): Very clayey very silty sand; sand is very fine to medium, with rare coarse sand, and is composed of limestone; dark gray (10YR 4/1); friable; moist; few sand-size fragments of land snail shells. Late Holocene channelmargin deposit with late Holocene to modern soil.

6-8 ft. (1.8-2.4 m): Small sample. Very clayey very silty sand; sand is very fine to medium, with rare coarse sand, and is composed of limestone; dark gray (10YR 4/1); friable; moist; few sand-size fragments of land snail shells. Late Holocene channel-margin deposit with late Holocene soil.

8-10 ft. (2.4-3.0 m): Small sample. Very clayey very silty sand; sand is very fine to medium, with rare coarse sand, and is composed of limestone; very dark gray to dark gray (10YR 3.5/1); friable; very moist; few sand-size fragments of land snail shells. Late Holocene overbank deposit with modern soil.

10-12 ft. (3.0-3.7 m): Very clayey very silty sand; sand is very fine to medium, with rare coarse sand, and is composed of limestone; very dark gray (10YR 3/1); friable; moist; few sand-size fragments of land snail shells. Middle(?) to late Holocene channel-margin deposit with middle(?) to late Holocene soil.

$12-13 \mathrm{ft} .(3.7-4.0 \mathrm{~m})$ : No sample.

13-15 ft. (4.0-4.6 m): Very clayey very silty slightly gravelly sand; sand is fine to very coarse and is composed of limestone; gravel consists of rounded limestone granules; very dark gray (10YR 3/1); friable; moist; few sand-size fragments of land snail shells. Early(?) to middle Holocene channel-margin deposit with early(?) to middle Holocene soil.

$15-18 \mathrm{ft}$. (4.6-5.5 m): No sample.

18-20 ft. (5.5-6.1 m): Very small sample, compressed and modified by testing; silty clay; yellowish brown (10YR 5/4) with few medium gray (10YR 5/1) mottles; friable; very moist. Late Pleistocene(?) to early Holocene overbank deposit with Late Pleistocene(?) to early Holocene soil.

20-23 ft. (6.1-7.0 m): No sample.

23-25 ft. (7.0-7.6 m): Slightly silty clay; dark grayish brown (10YR 4/2) with few fine gray (10YR 5/1) root mottles; friable; moist; few soft granule- to pebble-size calcareous masses. Late Pleistocene overbank deposit with Late Pleistocene soil partly developed in weathered bedrock (Upper Cretaceous Marlbrook Formation).

25-28 ft. (7.6-8.5 m): No sample.

28-30 ft. (8.5-9.1 m): Silty clay; yellowish brown (10YR 5/4) with few fine gray (10YR 5/1) root mottles; very hard; moist. Weathered bedrock (Upper Cretaceous Marlbrook Formation).

30-33 ft. (9.1-10.1 m): No sample.

33-35 ft. (10.1-10.7 m): Very small sample, modified by testing; silty clay; gray (10YR 6/1); very hard; dry. Weathered bedrock (Upper Cretaceous Marlbrook Formation).

35-38 ft. (10.7-11.6 m): No sample.

38-40 ft. (11.6-12.2 m): Very small sample, modified by testing; silty clay; gray (10YR 6/1); very hard; dry. Weathered bedrock (Upper Cretaceous Marlbrook Formation).

40-43 ft. (12.2-13.1 m): Very small sample, modified by testing; silty clay; gray (10YR 6/1); very hard; dry. Weathered bedrock (Upper Cretaceous Marlbrook Formation).

43-45 ft. (13.1-13.7 m): Mudstone; dark gray (10YR 4/1); laminated; extremely hard; dry. Bedrock (Upper Cretaceous Marlbrook Formation).

45-48 ft. (13.7-14.6 m): No sample.

48-50 ft. (14.6-15.2 m): Mudstone; dark gray (10YR 4/1); laminated; extremely hard; dry. Bedrock (Upper Cretaceous Marlbrook Formation). 
Table B-1. Continued...

\section{Borehole B-30}

South of W. Jones Avenue, right (western) bank, natural (unrectified) reach, $199.8 \mathrm{~m}$ AMSL.

0-2 ft. (0-0.6 m): Very silty gravelly to slightly gravelly sandy clay; sand is very fine to fine; gravel consists of rounded limestone granules with a few pebbles; black (10YR 2/1) varying to dark gray (10YR 4/1); loose to extremely firm; slightly moist; few fine pores; few sand-size land snail shell fragments; fibric organic matter. Modern overbank deposit with modern soil and intrusive modern earthen fill.

2-4 ft. (0.6-1.2 m): Very gravelly very silty sandy clay; sand is very fine to fine with rare medium to very coarse sand; gravel consists of rounded limestone granules and pebbles; brown (10YR 5/3) varying to very dark gray (10YR 3/1); very firm to extremely firm (compacted); slightly moist; few granule-size charcoal fragments. Modern overbank deposit with modern soil and intrusive modern earthen fill.

4-6 ft. (1.2-1.8 m): Very silty sandy locally gravelly to slightly gravelly clay; sand is very fine to fine with rare medium to very coarse sand; gravel consists of rounded limestone granules and pebbles; very dark gray (10YR 3/1) to dark gray (10YR 4/1); very firm; slightly moist; few granule-size charcoal fragments. Modern overbank deposit with modern soil and intrusive modern earthen fill.

6-8 ft. (1.8-2.4 m): Very silty sandy gravelly clay; sand is very fine to fine with rare medium to very coarse sand; gravel consists of rounded limestone granules and pebbles; very dark gray (10YR 3/1) to dark gray (10YR 4/1); very firm; slightly moist; few granule-size charcoal fragments. Modern overbank deposit with modern soil and intrusive modern earthen fill. 8-10 ft. (2.4-3.0 m): Very silty sandy slightly gravelly clay; sand is very fine to fine with rare medium to very coarse sand; gravel consists of rounded limestone pebbles; very dark gray (10YR 3/1) to dark gray (10YR 4/1); very firm; slightly moist; few granule-size charcoal fragments. Late Holocene channel-margin deposit with late Holocene soil and intrusive modern earthen fill.

10-12 ft. (3.0-3.7 m): Very clayey silty slightly sandy gravel; sand is very fine to fine, with rare medium to coarse sand; gravel consists of rounded limestone granules, pebbles, and rare cobbles; dark gray (10YR 4/1) with few pebble-size masses of dark yellowish brown (10YR 4/4) clay; friable; moist. Middle(?) to late Holocene channel deposit with late Holocene soil.

$12-15 \mathrm{ft} .(3.7-4.6 \mathrm{~m})$ : No sample.

15-16 ft. (4.6-4.9 m): Very silty very sandy clay; sand is fine to coarse; gray (10YR 5/1) to grayish brown (10YR 5/2); extremely firm; slightly moist; few calcareous filaments. Early(?) or middle Holocene channel-margin deposit with early(?) or middle Holocene soil.

$16-18 \mathrm{ft} .(4.9-5.5 \mathrm{~m})$ : No sample.

18-20 ft. (5.5-6.1 m): Very silty very sandy gravelly clay; sand is fine to coarse; gravel consists of rounded limestone granules and pebbles; gray (10YR 5/1) to grayish brown (10YR 5/2); extremely firm; slightly moist; few calcareous filaments. Late Pleistocene(?) or early Holocene channel deposit with Late Pleistocene(?) or early Holocene soil.

20-23 ft. (6.1-7.0 m): No sample.

23-25 ft. (7.0-7.6 m): Very silty slightly sandy clay; sand is very coarse; grayish brown (10YR 5/2) to yellowish brown (10YR 5/4); friable; moist; very sticky. Late Pleistocene channel-margin deposit and weathered bedrock (Upper Cretaceous Marlbrook Formation) with Late Pleistocene soil.

25-28 ft. (7.6-8.5 m): No sample.

28-30 ft. (8.5-9.1 m): Very silty slightly sandy clay; sand is mostly coarse to very coarse, but with micaceous coarse silt to very fine sand; brown (10YR 5/3); friable; moist; very sticky. Late Pleistocene channel-margin deposit and weathered bedrock (Upper Cretaceous Marlbrook Formation) with Late Pleistocene soil.

30-33 ft. (9.1-10.1 m): No sample.

33-35 ft. (10.1-10.7 m): Very silty slightly sandy clay; sand is mostly coarse to very coarse, but with micaceous coarse silt to very fine sand; very dark gray (10YR 3/1); laminated; friable; moist; very sticky. Early Holocene channel-margin deposit. Weathered bedrock (Upper Cretaceous Marlbrook Formation) with intrusive Late Pleistocene channel-margin sediment, overprinted with Late Pleistocene soil.

35-40 ft. (10.7-12.2 m): Slightly silty clay; very dark gray to dark gray (10YR 3.5/1); laminated; friable; moist. Weathered bedrock (Upper Cretaceous Marlbrook Formation).

40-43 ft. (12.2-13.1 m): No sample. 
Table B-1. Continued...

43-45 ft. (13.1-13.7 m): Slightly silty clay; dark gray (10YR 4/1); laminated; friable; moist. Weathered bedrock (Upper Cretaceous Marlbrook Formation).

45-48 ft. (13.7-14.6 m): No sample.

48-50 ft. (14.6-15.2 m): Slightly silty clay; dark gray to gray (10YR 4.5/1); laminated; very firm; moist; strong petroliferous odor from fresh break. Weathered bedrock (Upper Cretaceous Marlbrook Formation).

\section{Borehole B-32}

South of W. Jones Avenue, left (eastern) bank, rectified reach, $197.9 \mathrm{~m}$ AMSL.

$0-2 \mathrm{ft}$. $(0-0.6 \mathrm{~m})$ : Very silty sandy slightly gravelly clay; sand is very fine to fine; gravel consists of rounded limestone granules with a few pebbles; black (10YR 2/1) varying to dark gray (10YR 4/1); loose to extremely firm; slightly moist; few fine pores; few sand-size land snail shell fragments; fibric organic matter. Modern overbank deposit with modern soil and intrusive modern earthen fill.

$2-4 \mathrm{ft}$. $(0.6-1.2 \mathrm{~m})$ : Very gravelly very silty sandy clay; sand is very fine to fine with rare medium to very coarse sand; gravel consists of rounded limestone granules and pebbles; brown (10YR 5/3) varying to very dark gray (10YR 3/1); very firm; slightly moist; few granule-size partly decomposed wood fragments. Modern overbank deposit with modern soil and intrusive modern earthen fill.

4-6 ft. (1.2-1.8 m): Silty clay; light brownish gray (10YR 6/2) to light yellowish brown (10YR 6/4); very firm; moist; very sticky; few soft pebble-size calcareous nodules. Late Holocene overbank deposit with late Holocene soil.

6-8 ft. (1.8-2.4 m): Silty clay; light brownish gray (10YR 6/2) to light yellowish brown (10YR 6/4); very firm; moist; very sticky; common soft pebble-size calcareous nodules. Late Holocene overbank deposit with late Holocene soil.

8-10 ft. (2.4-3.0 m): Silty clay; light brownish gray (10YR 6/2) to light yellowish brown (10YR 6/4); very firm; moist; very sticky; few soft pebble-size calcareous nodules. Middle(?) or late Holocene overbank deposit with middle(?) or late Holocene soil.

10-12 ft. (3.0-3.7 m): Silty clay; light brownish gray (10YR 6/2) to light yellowish brown (10YR 6/4); very firm; moist; very sticky; few soft medium sand- to granule-size calcareous nodules. Middle(?) Holocene overbank deposit with middle(?) Holocene soil.

$12-14 \mathrm{ft} .(3.7-4.3 \mathrm{~m})$ : No sample.

14-16 ft. (4.3-4.9 m): Silty clay; light brownish gray (10YR 6/2) to light yellowish brown (10YR 6/4); very firm; moist; very sticky; few soft medium sand- to granule-size calcareous nodules. Early Holocene overbank deposit with early Holocene soil. $16-18 \mathrm{ft} .(4.9-5.5 \mathrm{~m})$ : No sample.

18-20 ft. (5.5-6.1 m): Very silty clay; brownish yellow (10YR 6/8); laminated to thin bedded; extremely firm; moist. Weathered bedrock (Upper Cretaceous Marlbrook Formation).

20-23 ft. (6.1-7.0 m): No sample.

23-25 ft. (7.0-7.6 m): Very silty clay; brownish yellow (10YR 6/8); laminated to thin bedded; extremely firm; moist. Weathered bedrock (Upper Cretaceous Marlbrook Formation).

$25-28 \mathrm{ft}$. (7.6-8.5 m): No sample.

28-30 ft. (8.5-9.1 m): Slightly silty clay; very dark gray to dark gray (10YR 3.5/1); laminated; friable; moist. Weathered bedrock (Upper Cretaceous Marlbrook Formation).

30-33 ft. (9.1-10.1 m): No sample.

$33-35 \mathrm{ft}$. (10.1-10.7 m): Very silty slightly sandy clay; sand is mostly coarse to very coarse, but with micaceous coarse silt to very fine sand; very dark gray (10YR 3/1); laminated; friable; moist; very sticky. Early Holocene channel-margin deposit. Weathered bedrock (Upper Cretaceous Marlbrook Formation) with intrusive early Holocene channel-margin sediment, overprinted with early Holocene soil.

$35-38 \mathrm{ft}$. (10.7-11.6 m): No sample.

$38-40 \mathrm{ft}$. (11.6-13.1 m): Very silty slightly sandy clay; sand is mostly coarse to very coarse, but with micaceous coarse silt to very fine sand; very dark gray (10YR 3/1); laminated; friable; moist; very sticky. Early Holocene channel-margin deposit. Weathered bedrock (Upper Cretaceous Marlbrook Formation) with intrusive early Holocene channel-margin sediment, overprinted with early Holocene soil. 
Table B-1. Continued...

\section{Borehole B-39}

South of Ninth St., right (western) bank, rectified reach, $198.6 \mathrm{~m}$ AMSL.

0-2 ft. (0-0.6 m): Very silty sandy clay, admixed with subangular pebble-size fragments of limestone; sand is very fine to fine; black (10YR 2/1); loose to extremely firm; slightly moist. Modern overbank deposit with modern soil and intrusive modern earthen fill.

2-4 ft. (0.6-1.2 m): Mixed sample (two discrete components): silty clay, admixed with subangular pebble-size fragments of limestone; black (10YR 2/1); extremely firm (compacted); slightly moist; and clay; dark gray (10YR 4/1); friable; moist; common calcareous filaments and few soft granule-size calcareous nodules. Modern overbank deposit with modern soil and intrusive modern earthen fill, overlying late Holocene overbank deposit with late Holocene soil.

4-6 ft. (1.2-1.8 m): Very silty clay; brown (10YR 5/3) to yellowish brown (10YR 5/4); friable; moist; common calcareous filaments and few soft granule-size calcareous nodules. Late Holocene overbank deposit with late Holocene soil.

6-8 ft. (1.8-2.4 m): Very silty clay with a single rounded chert pebble (intrusive?); brown (10YR 5/3) to yellowish brown (10YR 5/4); friable; moist; common calcareous filaments and common soft pebble-size calcareous nodules; few sand-size land snail shell fragments. Late Holocene overbank deposit with late Holocene soil.

8-10 ft. (2.4-3.0 m): Very silty clay; brown (10YR 5/3) to yellowish brown (10YR 5/4); friable; moist; common calcareous filaments and common soft pebble-size calcareous nodules; few sand-size land snail shell fragments. Middle(?) to late Holocene overbank deposit with middle(?) to late Holocene soil.

10-12 ft. (3.0-3.7 m): Clay; light gray (10YR 7/2) to light brownish gray (10YR 6/2); color variation is due in part to oxidation-reduction along poorly-defined root conduits; very firm; moist; many soft granule- to pebble-size calcareous nodules. Middle(?) Holocene overbank deposit with middle(?) Holocene soil.

$12-14 \mathrm{ft} .(3.7-4.3 \mathrm{~m})$ : No sample.

14-16 ft. (4.3-4.9 m): Sandy gravel; sand is very fine to medium; gravel consists of rounded limestone and chert granules and pebbles; light brownish gray (10YR 6/2) to light yellowish brown (10YR 6/4); extremely firm; moist; calcareous cemented (all interstices filled). Early(?) Holocene channel deposit with early(?) Holocene soil.

$16-18 \mathrm{ft} .(4.9-5.5 \mathrm{~m})$ : No sample.

18-20 ft. (5.5-6.1 m): Clay; yellowish brown (10YR 5/4) with few fine light gray (10YR 7/2) root mottles; firm; moist; few soft granule- to pebble-size calcareous nodules. Weathered bedrock (Upper Cretaceous Marlbrook Formation) with Late Pleistocene to early Holocene(?) soil.

20-23 ft. (6.1-7.0 m): No sample.

23-25 ft. (7.0-7.6 m): Very silty clay; yellowish brown (10YR 5/4); firm; moist; few soft pebble-size calcareous masses of clear fine to very coarse sand-size calcite crystals. Weathered bedrock (Upper Cretaceous Marlbrook Formation) with Late Pleistocene to early Holocene(?) soil.

25-28 ft. (7.6-8.5 m): No sample.

28-30 ft. (8.5-9.1 m): Silty clay; yellowish brown to brown (10YR 5/3.5); firm; moist; few soft pebble-size calcareous nodules and soft pebble-size calcareous masses of clear fine to very coarse sand-size calcite crystals. Weathered bedrock (Upper Cretaceous Marlbrook Formation) with Late Pleistocene to early Holocene(?) soil.

30-33 ft. (9.1-10.1 m): No sample.

33-35 ft. (10.1-10.7 m): Mudstone; dark gray (10YR 4/1); laminated; extremely hard; dry; calcareous efflorescence on breaks. Bedrock (Upper Cretaceous Marlbrook Formation).

35-38 ft. (10.7-11.6 m): No sample.

38-40 ft. (11.6-12.2 m): Mudstone; dark gray (10YR 4/1); laminated; extremely hard; dry; calcareous efflorescence on breaks. Bedrock (Upper Cretaceous Marlbrook Formation).

40-43 ft. (12.2-13.1 m): No sample.

43-45 ft. (13.1-13.7 m): Mudstone with very fine sand laminae; dark gray (10YR 4/1); laminated; extremely hard; dry; calcareous efflorescence on breaks. Bedrock (Upper Cretaceous Marlbrook Formation).

45-48 ft. (13.7-14.6 m): No sample.

48-50 ft. (14.6-15.2 m): Mudstone; light gray (10YR 7/2); laminated; extremely hard; dry. Bedrock (Upper Cretaceous Marlbrook Formation). 
Table B-1. Continued...

\section{Borehole B-46}

North of Brooklyn Ave., right (western) bank, rectified reach, 196.3 m AMSL.

0-2 ft. (0-0.6 m): Silty clay, admixed with medium to very coarse limestone sand and few rounded limestone pebbles; very dark gray to dark gray (10YR 3.5/1); friable; moist; fibric organic matter. Modern overbank deposit with modern soil and intrusive modern earthen fill.

2-4 ft. (0.6-1.2 m): Slightly silty clay, admixed with medium to very coarse limestone sand and few rounded limestone and calcareous sandstone pebbles; very dark gray to dark gray (10YR 3.5/1); friable; moist; fibric organic matter; few granulesize fragments of charcoal. Modern overbank deposit with modern soil and intrusive modern earthen fill.

4-6 ft. (1.2-1.8 m): Slightly silty clay, admixed with medium to very coarse limestone sand and few rounded limestone and calcareous sandstone pebbles; very dark gray to dark gray (10YR 3.5/1); firm (compacted); moist; fibric organic matter; few granule-size fragments of charcoal. Modern overbank deposit with modern soil and intrusive modern earthen fill.

6-8 ft. (1.8-2.4 m): Silty clay, admixed with limestone cobble; dark gray (10YR 4/1); friable; moist; fibric organic matter; few granule-size fragments of charcoal. Modern overbank deposit with modern soil and intrusive modern earthen fill. 8-10 ft. (2.4-3.0 m): Silty clay with laminae composed of very fine to very coarse sand, granules, and rare pebbles; very dark gray (10YR 3/1); friable; moist; few sand-size fragments of land snail shells. Late Holocene overbank deposit with late Holocene soil.

10-12 ft. (3.0-3.7 m): Very silty clay; dark grayish brown (10YR 4/2); very friable; moist. Middle(?) to late Holocene overbank deposit with late Holocene soil.

$12-13 \mathrm{ft} .(3.7-4.0 \mathrm{~m})$ : No sample.

13-15 ft. (4.0-4.6 m): Small sample, modified by testing. Very silty clay; light brownish gray (10YR 6/2); hard; dry. Middle(?) Holocene overbank deposit with middle(?) Holocene soil.

$15-18$ ft. (4.6-5.5 m): No sample.

18-20 ft. (5.5-6.1 m): Silty clay; yellowish brown (10YR 5/6); very firm; slightly moist. Early(?) to middle Holocene overbank deposit with early(?) to middle Holocene soil.

20-23 ft. (6.1-7.0 m): No sample.

23-25 ft. (7.0-7.6 m): Small sample. Silty gravelly clay; gravel consists of rounded limestone and chert pebbles; light brownish gray (10YR 6/2); extremely hard; dry. Late Pleistocene channel deposit with Late Pleistocene soil.

25-28 ft. (7.6-8.5 m): No sample.

28-30 ft. (8.5-9.1 m): Very silty clay; dark gray (10YR 4/1); very firm; moist. Late Pleistocene overbank deposit with Late Pleistocene soil.

30-33 ft. (9.1-10.1 m): No sample.

33-35 ft. (10.1-10.7 m): Very silty clay; dark gray (10YR 4/1); very firm; moist; few medium sand-size fragments of land snail shell. Late Pleistocene overbank deposit with Late Pleistocene soil.

35-38 ft. (10.7-11.6 m): No sample.

38-40 ft. (11.6-12.2 m): Very silty clay; dark gray (10YR 4/1); very firm; moist; few soft granule- to pebble-size calcareous masses. Weathered bedrock (Upper Cretaceous Marlbrook Formation) with Late Pleistocene to early Holocene(?) soil. 40-43 ft. (12.2-13.1 m): No sample.

43-45 ft. (13.1-13.7 m): Very silty clay; dark gray (10YR 4/1); very firm; moist; many soft granule- to pebble-size calcareous masses, some laterally linked. Weathered bedrock (Upper Cretaceous Marlbrook Formation) with Late Pleistocene soil. 45-48 ft. (13.7-14.6 m): No sample.

48-50 ft. (14.6-15.2 m): Very silty clay; dark gray (10YR 4/1); very firm; moist; few soft granule- to pebble-size calcareous masses, some laterally linked. Weathered bedrock (Upper Cretaceous Marlbrook Formation) with Late Pleistocene soil. 50-53 ft. (15.2-16.2 m): No sample.

53-55 ft. (16.2-16.8 m): Very silty clay; dark gray (10YR 4/1); very firm; moist; few soft granule- to pebble-size calcareous masses, some laterally linked. Weathered bedrock (Upper Cretaceous Marlbrook Formation) with Late Pleistocene soil. 55-58 ft. (16.8-17.7 m): No sample.

58-60 ft. (17.7-18.3 m): Very silty clay with an isolated rounded chert pebble (down-hole contaminant?); gray (10YR 5/1); laminated; extremely hard; dry. Weathered bedrock (Upper Cretaceous Marlbrook Formation). 
Table B-1. Continued...

(60-63 ft. (18.3-19.2 m): No sample.

63-65 ft. (19.2-19.8 m): Mudstone; gray (10YR 6/1); laminated; extremely hard; dry. Bedrock (Upper Cretaceous Marlbrook Formation).

65-68 ft. (19.8-20.7 m): No sample.

68-70 ft. (20.7-21.3 m): Mudstone; gray (10YR 6/1); laminated; extremely hard; dry. Bedrock (Upper Cretaceous Marlbrook Formation).

\section{Borehole B-60}

South of McCullough Ave., left (eastern) bank, rectified reach, $197.8 \mathrm{~m}$ AMSL. $0-2$ ft. (0-0.6 m): No sample.

2-4 ft. (0.6-1.2 m): Small sample. Very silty clay, admixed with granules of crushed limestone and bituminous coal; gray (10YR 5/1); hard; dry. Modern overbank deposit with modern soil and intrusive modern earthen fill.

4-6 ft. $(1.2-1.8 \mathrm{~m})$ : No sample.

6-8 ft. (1.8-2.4 m): Slightly silty clay; dark grayish brown (10YR 4/2) to grayish brown (10YR 5/2) with common very fine light yellowish brown (10YR 6/4) mottles; very friable; moist; few hard granule-size calcareous nodules; few sandsize fragments of land snail shells. Late Holocene overbank deposit with late Holocene soil.

8-10 ft. (2.4-3.0 m): Slightly silty clay; dark grayish brown (10YR 4/2) to grayish brown (10YR 5/2) with many fine yellowish brown (10YR 5/6) mottles; very friable; moist; common hard granule-size calcareous nodules; few sand-size fragments of land snail shells. Late Holocene overbank deposit with late Holocene soil.

10-12 ft. (3.0-3.7 m): Small sample. Slightly gravelly sand; sand is fine; gravel consists of limestone granules; white (10YR 8/1); hard; dry; calcareous cemented (all interstices filled). Early(?) to middle Holocene channel-margin deposit with early(?) to middle Holocene soil.

12-14 ft. (3.7-4.3 m): No sample.

14-16 ft. (4.3-4.9 m): Slightly gravelly sand; sand is fine; gravel consists of limestone granules; yellow (10YR 7/6); hard; dry; calcareous cemented (all interstices filled); few pebble-size spherical calcareous concretions. Early(?) Holocene channelmargin deposit with early(?) Holocene soil.

$16-18 \mathrm{ft}$. (4.9-5.5 m): No sample.

18-20 ft. (5.5-6.1 m): Very silty slightly sandy clay; sand is very fine; dark yellowish brown (10YR 4/4); very friable; moist. Weathered bedrock (Upper Cretaceous Marlbrook Formation) with Late Pleistocene to early Holocene(?) soil.

20-23 ft. (6.1-7.0 m): No sample.

23-25 ft. (7.0-7.6 m): Slightly silty clay; brown (10YR 5/3) to yellowish brown (10YR 5/4) with few fine light brownish gray (10YR 6/2) root mottles; friable; moist; few hard granule-size calcareous nodules. Weathered bedrock (Upper Cretaceous Marlbrook Formation) with Late Pleistocene soil.

25-28 ft. (7.6-8.5 m): No sample.

28-30 ft. (8.5-9.1 m): Slightly silty clay; brown (10YR 5/3) to yellowish brown (10YR 5/4) with few fine light brownish gray (10YR 6/2) root mottles; friable; slightly moist; few hard granule-size calcareous nodules. Weathered bedrock (Upper Cretaceous Marlbrook Formation) with Late Pleistocene soil.

30-33 ft. (9.1-10.1 m): No sample.

33-35 ft. (10.1-10.7 m): Clayey silty sand to slightly silty clay; sand is very fine to fine; brown (10YR 5/3) to brownish yellow (10YR 6/6) with few fine light gray (10YR 7/1) root mottles; hard; dry. Weathered bedrock (Upper Cretaceous Marlbrook Formation) with Late Pleistocene soil.

35-38 ft. (10.7-11.6 m): No sample.

38-40 ft. (11.6-12.2 m): Mudstone; gray (10YR 5/1); extremely hard; dry. Bedrock (Upper Cretaceous Marlbrook Formation).

\section{Borehole B-63}

North of Lexington Ave., left (eastern) bank, natural (unrectified) reach, $198.0 \mathrm{~m}$ AMSL.

0-2 ft. (0-0.6 m): Crushed limestone, admixed with silty clay; fine-grained sediment is gray (10YR 5/1); loose; dry. Modern overbank deposit(?) with modern earthen fill. 
Table B-1. Continued...

2-4 ft. (0.6-1.2 m): Crushed limestone and rounded limestone pebbles, admixed with silty clay; fine-grained sediment is gray (10YR 5/1); loose; dry. Modern overbank deposit with modern soil and modern earthen fill.

4-6 ft. (1.2-1.8 m): Silty slightly sandy clay; sand is very fine; black (10YR 2/1); extremely hard; dry; few whole ostracode valves; few sand-sized fragments of land snail shells. Late Holocene(?) to modern overbank deposit with modern soil.

6-8 ft. (1.8-2.4 m): Slightly silty slightly sandy clay; sand is very fine; very dark grayish brown (10YR 3/2); extremely hard; dry; few sand-sized fragments of land snail shells. Late Holocene to modern overbank deposit with late Holocene to modern soil. Sample S1: Conventional radiocarbon age, $1990 \pm 70 \mathrm{BP} ; \delta^{13} \mathrm{C},-17.4 \%$.

$8-10 \mathrm{ft}$. (2.4-3.0 m): Silty slightly sandy clay; sand is very fine; dark grayish brown (10YR 4/2); weak fine angular blocky structure; friable; slightly moist; few calcareous filaments; few fine pores; few fine casts. Late Holocene overbank deposit with middle to late Holocene soil. Sample S2: Conventional radiocarbon age, $2460 \pm 70 \mathrm{BP} ; \delta^{13} \mathrm{C},-20.0 \%$.

$10-12 \mathrm{ft}$. (3.0-3.7 m): Silty slightly sandy clay; sand is very fine; dark grayish brown (10YR 4/2); weak fine angular blocky structure; friable; slightly moist; many soft coarse sand- to granule-size coarsely crystalline calcareous nodules; few calcareous filaments; few fine pores; few fine casts. Late Holocene overbank deposit with late Holocene soil. Sample S3: Conventional radiocarbon age, $2760 \pm 70 \mathrm{BP} ; \delta^{13} \mathrm{C},-19.2 \%$.

$12-14 \mathrm{ft} .(3.7-4.3 \mathrm{~m})$ : No sample.

$14-16 \mathrm{ft}$. (4.3-4.9 m): Very clayey silty sand; sand is very fine to fine with rare medium to coarse sand; grayish brown (10YR 5/2) with many fine to medium irregular brownish yellow (10YR 6/6) mottles; friable; slightly moist. Middle(?) Holocene channel-margin deposit with late Holocene soil. Sample S4: Conventional radiocarbon age, $2930 \pm 70 \mathrm{BP} ; \delta^{13} \mathrm{C}$, $-22.2 \%$.

$16-18 \mathrm{ft} .(4.9-5.5 \mathrm{~m})$ : No sample.

18-20 ft. (5.5-6.1 m): Slightly silty clay; yellowish brown (10YR 5/4) to light yellowish brown (10YR 6/4) with few fine gray (10YR 6/1) root mottles; friable; slightly moist. Weathered bedrock (Upper Cretaceous Marlbrook Formation) with early Holocene(?) soil.

20-23 ft. (6.1-7.0 m): No sample.

23-25 ft. (7.0-7.6 m): Slightly silty clay; yellowish brown (10YR 5/4) to light yellowish brown (10YR 6/4) with few fine gray (10YR 6/1) root mottles; friable; slightly moist. Weathered bedrock (Upper Cretaceous Marlbrook Formation) with Late Pleistocene(?) soil.

$25-28 \mathrm{ft}$. (7.6-8.5 m): No sample.

28-30 ft. (8.5-9.1 m): Slightly silty clay; yellowish brown (10YR 5/4) to light yellowish brown (10YR 6/4) with few fine gray (10YR 6/1) root mottles; few calcareous filaments; friable; slightly moist. Weathered bedrock (Upper Cretaceous Marlbrook Formation) with Late Pleistocene soil.

30-33 ft. (9.1-10.1 m): No sample.

33-35 ft. (10.1-10.7 m): Slightly silty clay; dark yellowish brown (10YR 4/4) to yellowish brown (10YR 5/4); friable; slightly moist. Weathered bedrock (Upper Cretaceous Marlbrook Formation) with Late Pleistocene soil.

$35-38$ ft. (10.7-11.6 m): No sample.

38-40 ft. (11.6-12.2 m): Small sample; silty slightly clayey sand; sand is very fine to fine; grayish brown (10YR 5/2) with common fine to medium irregular light grayish brown (10YR 6/2) mottles; extremely hard; dry. Bedrock (Upper Cretaceous Marlbrook Formation).

40-43 ft. (12.2-13.1 m): No sample.

43-45 ft. (13.1-13.7 m): Mudstone; very dark gray to dark gray (10YR 3.5/1); very hard; dry. Bedrock (Upper Cretaceous Marlbrook Formation). 
Table B-1. Continued...

\section{Borehole B-64}

North of Lexington Ave., left (eastern) bank, rectified reach, 198.1 m AMSL.

0-2 ft. (0-0.6 m): Small sample; silty clay, admixed with rounded limestone pebbles and angular pebble-size fragments of crushed limestone; fine-grained sediment is very dark gray (10YR 3/1); loose; dry. Modern overbank deposit(?) with modern earthen fill.

2-4 ft. (0.6-1.2 m): Small sample; silty clay, admixed with rounded limestone pebbles and angular pebble-size fragments of crushed limestone; fine-grained sediment is very dark gray (10YR 3/1); loose; dry. Modern overbank deposit(?) with modern earthen fill.

4-6 ft. (1.2-1.8 m): Silty clay, admixed with rounded limestone pebbles and angular pebble-size fragments of crushed limestone; fine-grained sediment is very dark gray (10YR 3/1); loose; dry. Modern overbank deposit(?) with modern earthen fill.

6-8 ft. (1.8-2.4 m): No sample.

8-10 ft. (2.4-3.0 m): Very sandy silty clay; sand is very fine to fine with rare medium sand; very dark gray (10YR 3/1); extremely hard; dry. Late Holocene channel-margin deposit with late Holocene soil.

10-12 ft. (3.0-3.7 m): Silty slightly sandy clay; sand is very fine; very dark gray (10YR 3/1); extremely hard; dry. Middle(?) to late Holocene overbank deposit with middle(?) to late Holocene soil.

12-14 ft. (3.7-4.3 m): No sample.

14-16 ft. (4.3-4.9 m): Silty clay; very dark gray (10YR 3/1); moderate fine angular blocky structure; extremely hard; dry; few hard granule-size calcareous nodules; many calcareous filaments. Middle(?) Holocene overbank deposit with middle(?) Holocene soil.

$16-18 \mathrm{ft} .(4.9-5.5 \mathrm{~m})$ : No sample.

18-20 ft. (5.5-6.1 m): Very clayey very silty sand; sand is very fine to fine; dark gray (10YR 4/1) to black (10YR 2/1); relict thin bedding; friable; moist; highly carbonaceous; low density. Early(?) Holocene channel-margin deposit with early(?) Holocene soil.

20-23 ft. (6.1-7.0 m): No sample.

23-25 ft. (7.0-7.6 m): Silty clay; yellowish brown (10YR 4/6 to 10YR 5/6) with few fine gray (10YR 5/1) root mottles; very firm; slightly moist. Weathered bedrock (Upper Cretaceous Marlbrook Formation) with Late Pleistocene soil.

25-28 ft. (7.6-8.5 m): No sample.

28-30 ft. (8.5-9.1 m): Silty clay; yellowish brown (10YR 4/6 to 10YR 5/6) with few fine gray (10YR 5/1) root mottles; very firm; slightly moist. Weathered bedrock (Upper Cretaceous Marlbrook Formation) with Late Pleistocene soil.

30-33 ft. (9.1-10.1 m): No sample.

33-35 ft. (10.1-10.7 m): Silty clay; very dark gray (10YR 3/1); very firm; slightly moist. Weathered bedrock (Upper Cretaceous Marlbrook Formation) with Late Pleistocene soil.

35-38 ft. (10.7-11.6 m): No sample.

38-40 ft. (11.6-12.2 m): Small sample; silty slightly clayey sand; sand is very fine to fine; grayish brown (10YR 5/2) with common fine to medium irregular light grayish brown (10YR 6/2) mottles; extremely hard; dry. Weathered bedrock (Upper Cretaceous Marlbrook Formation). 
Table B-2. Radiocarbon and Carbon Stable-Isotope Analyses of Humate Samples

\begin{tabular}{llccc} 
ISGS \# & Sample Context \& Number & Depth BGS (m) & Age RCYBP & $\boldsymbol{\delta}^{\mathbf{1 3}} \mathbf{C ~ \% o}$ \\
\hline 5912 & Borehole 2, Sample 1 & $1.8-2.4$ & $1580 \pm 70$ & -20.7 \\
5913 & Borehole 2, Sample 2 & $2.4-3.0$ & $2310 \pm 70$ & -21.1 \\
5914 & Borehole 2, Sample 3 & $3.0-3.7$ & $2360 \pm 70$ & -22.1 \\
\hline 5920 & Borehole 23, Sample 1 & $1.8-2.4$ & $1630 \pm 70$ & -19.0 \\
5921 & Borehole 23, Sample 2 & $3.0-3.7$ & $2140 \pm 70$ & -21.2 \\
5922 & Borehole 23, Sample 3 & $7.0-7.6$ & $18,070 \pm 560$ & -29.0 \\
\hline 5923 & Borehole 63, Sample 1 & $1.8-2.4$ & $1190 \pm 70$ & -17.4 \\
5924 & Borehole 63, Sample 2 & $2.4-3.0$ & $2460 \pm 70$ & -20.0 \\
5925 & Borehole 63, Sample 3 & $3.0-3.7$ & $2760 \pm 70$ & -19.2 \\
5926 & Borehole 63, Sample 4 & $4.3-4.9$ & $2930 \pm 90$ & -22.2 \\
\hline 5915 & Backhoe Trench 8, Sample 3 & $0.81-0.96$ & $2060 \pm 70$ & -18.8 \\
5918 & Backhoe Trench 8, Sample 4 & $1.28-1.50$ & $2980 \pm 70$ & -19.7 \\
5919 & Backhoe Trench 8, Sample 5 & $1.80-2.00$ & $3580 \pm 70$ & -19.1 \\
\hline
\end{tabular}

\section{Explanation}

ISGS: Illinois State Geological Survey, Isotope Geochemistry Section, Radiocarbon Laboratory. Sample context, number: Borehole numbers based on Bacon (2005); backhoe-trench and sample numbers from the present study.

Depth BGS (m): Depth below ground surface in meters.

Age RCYBP: Age in radiocarbon years before present (conventional radiocarbon age, i.e., $\delta^{13} \mathrm{C}$ corrected, but not calibrated).

$\delta^{13} \mathbf{C} \%$ : Carbon stable-isotope ratio in parts per thousand. 


\title{
Pollen Extraction and Summary of 15 Sediment Samples from San Antonio River Improvement Project (SARIP), Bexar County, Texas
}

\author{
Vaughn M. Bryant \\ Palynology Laboratory \\ Texas A\&M University, College Station
}




\section{Appendix C: Pollen Extraction and Summary of 15 Sediment Samples from San Antonio River Improvement Project (SARIP)}

\section{Sample Data Base}

The current study focuses on 15 pollen samples from several locations along the Museum "Urban" Reach section of the San Antonio River Improvements Project (SARIP) located in San Antonio, Bexar County, Texas. The pollen samples examined in this study are listed in Table C-1.

\section{Pollen Extraction}

There are a number of articles, chapters, and even books on methods that one can use to successfully extract fossil pollen from various types of sediments (Hunt 1985; Riding and Kyffin-Hughes 2004), including some articles that focus specifically on techniques used for archaeological sediments (Bryant 1988; Bryant and Holloway 1983; Coil et al. 2003).

Pollen extraction is a critical part of any project because the use of certain acids and methods can lead to the loss of fossil pollen, while other methods may not remove enough of the detritus to permit accurate identification of the fossil pollen in the remaining residue. For these reasons, it is essential that reports, such as this, include the precise methods used during the extraction procedure so that the reader can be assured that pollen recovery was maximized and that fossil pollen was not inadvertently destroyed or lost during processing.

Facilities: All work for this project was conducted using sterile, surgical gloves in the sealed TAMU Palynology Laboratory under a fume hood. In addition, glycerin-coated slides are left exposed in various locations within the lab and they are checked weekly for any signs of outside pollen contamination. None were noted during processing or after this project was completed. Thus, I am certain that none of the pollen found came from contamination in the facility.

Pollen Extraction Procedures: The extraction procedure used for these samples consisted of the following steps.

1. From each sample, I removed 20 grams of soil and placed it in a $600 \mathrm{ml}$ plastic beaker. Next, I added

Table C-1. SARIP Soil Samples Collected for Pollen Studies

\begin{tabular}{|c|c|c|}
\hline Sample \# & Sample Provenience & Weight of Sample Processed \\
\hline \multirow{2}{*}{1} & Ninth Street Locality, Backhoe Trench 3 & \\
\hline & Stratum 1 Sample S1: Pollen & 20 grams (pollen) \\
\hline \multirow{2}{*}{2} & Ninth Street Locality, Backhoe Trench 3 & \\
\hline & Stratum 2 Sample S2: Pollen & 20 grams (pollen) \\
\hline \multirow{2}{*}{3} & Ninth Street Locality, Backhoe Trench 3 & \\
\hline & Stratum 2 Sample S3: Pollen & 20 grams (pollen) \\
\hline \multirow{2}{*}{4} & Ninth Street Locality, Backhoe Trench 3 & \\
\hline & Stratum 3 Sample S4: Pollen & 20 grams (pollen) \\
\hline \multirow{2}{*}{5} & Ninth Street Locality, Backhoe Trench 3 & \\
\hline & Stratum 4 Sample S5: Pollen & 20 grams (pollen) \\
\hline 6 & Borehole 2 Sample 1: Pollen & 20 grams (pollen) \\
\hline 7 & Borehole 2 Sample 2: Pollen & 20 grams (pollen) \\
\hline 8 & Borehole 2 Sample 3: Pollen & 20 grams (pollen) \\
\hline 9 & Borehole 23 Sample 1: Pollen & 20 grams (pollen) \\
\hline 10 & Borehole 23 Sample 2: Pollen & 20 grams (pollen) \\
\hline 11 & Borehole 23 Sample 3: Pollen & 20 grams (pollen) \\
\hline 12 & Borehole 23 Sample 4: Pollen & 20 grams (pollen) \\
\hline 13 & Borehole 63 Sample 1: Pollen & 20 grams (pollen) \\
\hline 14 & Borehole 63 Sample 2: Pollen & 20 grams (pollen) \\
\hline 15 & Borehole 63 Sample 3: Pollen & 20 grams (pollen) \\
\hline
\end{tabular}


$50 \mathrm{ml}$ of concentrated hydrochloric acid $(\mathrm{HCl})$, to dissolve calcium carbonates in the soil, and two Lycopodium tablets each of which contained 13,520 tracer spores. I used two tablets because the vast majority of pollen samples I have examined from the arid regions of Texas and the American Southwest suggest that pollen counts rarely exceed 54,000 pollen grains per gram of soil. Thus the ratio of tracer spores to fossil pollen in each gram of soil is rarely greater than a ratio of 1:2.

The use of tracer spores in pollen samples has been extensively studied by Louis Maher (1981) and others. Maher noted that the number of tracer spores added to samples should be in a ratio of between 1:1 and 1:2 (tracer spores vs. fossil pollen) to achieve statistically accurate calculations of fossil pollen concentrations per gram or milliliter of sediment. I use Lycopodium spores as a tracer in most sediment from sites in the temperate and arid regions of the United States because it is extremely rare to find naturally occurring Lycopodium plants growing in these regions. Therefore, the only potential source of these spores in the samples I examined is most probably the tablets that were added.

After all reaction with the $\mathrm{HCl}$ had stopped, I filled the beaker with distilled water and allowed the beaker to stand for four hours. After that, the liquid portion was carefully poured off. Pollen will remain suspended in water for various periods of time, but after four hours, fossil pollen will settle to the bottom of a container and thus the liquid portion can be poured off without loss of fossil pollen (Lentfer et al. 2003). The remaining sediment in the beaker was spun down using $50 \mathrm{ml}$ centrifuge tubes (CT) in a centrifuge and the liquid was then poured off. This process was repeated twice.

2. I then added $15 \mathrm{ml}$ of concentrated hydrofluoric acid (HF) $(56 \%)$ to the sediment in the CT, stirred the sample, and let it sit overnight in the fume hood. I might caution others that this is very dangerous and that the HF must be added very slowly at the rate of only 1-2 $\mathrm{ml}$ at a time. The sample must then be thoroughly stirred and allowed to sit for one minute before adding more HF. Some sediments, especially those containing finegrained clays and mica, will react violently to the HF once the sediment reaches a high temperature caused by the rapid dissolving of some of the fine-grained silicates. After HF is added, it will slowly heat the sediment as it begins to react with the silicates. If one adds too much HF at first, once it heats to a certain temperature, the HF will "explode" out of the top of the CT and hot HF will cover everything in the fume hood. This will not only "ruin" the original sample, but can contaminate other samples under the fume hood and will deposit the HF on all the counter surfaces, which must then be neutralized with sodium bicarbonate $\left(\mathrm{NaHCO}_{3}\right)$. Worst of all, if the processor is standing in front of the fume hood when this occurs; he will also be peppered with HF, which can cause permanent injury and even death to the individual.

The HF process removes most of the fine-grained silicates from the sample and does not damage the pollen. The next day I filled the CT with distilled water, spun it down, rinsed it twice with distilled water, and then filled the $\mathrm{CT}$ with concentrated $\mathrm{HCl}$. This $\mathrm{HCl}$ step is necessary to ensure removal of fluorosilicates in the sample, which often form as a result of the HF treatment. After two or three $\mathrm{HCl}$ rinses, the samples were rinsed again in distilled water twice.

4. Next I transferred the material in each sample to a $15 \mathrm{ml}$ $\mathrm{CT}$ and then added $10 \mathrm{ml}$ of $5 \%$ potassium hydroxide $(\mathrm{KOH})$ and heated them for 10 minutes at $180^{\circ} \mathrm{F}$. This was followed by two washes in distilled water.

5. Next, I added $10 \mathrm{ml}$ of concentrated $\mathrm{HCl}$ and heated each sample for one minute. I then spun down the sample, poured out the liquid and again rinsed the sample twice in distilled water. This $\mathrm{HCl}$ step is essential to remove any remaining humic acids and dissolved compounds that might be present in each sample after the $\mathrm{KOH}$ treatment, but are not removed during repeated water washings.

6. Each sample was then rinsed in glacial acetic acid, centrifuged, and then the glacial acetic acid was carefully poured off.

7. Next, I added $10 \mathrm{ml}$ of a mixture of 1 part sulfuric acid to 9 parts acetic anhydride. This is known as the acetolysis process (Erdtman 1960). After heating each sample in a heating block at $180^{\circ} \mathrm{F}$ for 10 minutes, I centrifuged the solution and then poured off the liquid.

8. I then rinsed each sample in glacial acetic acid and after centrifuging, I poured off the glacial acetic acid.

9. Next, the samples were rinsed twice in distilled water. 
10. The next step was to fill each CT one-half full of zinc bromide $\left(\mathrm{ZnBr}_{2}\right)$, which has a specific gravity of 2.0. That solution was thoroughly mixed with a wooden stick in the sample for 60 seconds as it was being spun on a vortex stirrer to ensure complete mixing of all solid material in the CT. I then let the samples sit for 5 minutes. After that I spun the samples at 500 RPMs for 5 minutes. When that was completed, I very carefully used a pipette to remove the upper part of the $\mathrm{ZnBr}_{2}$, which contained all of the pollen and tracer spores. I then checked the material that was at the bottom of each CT to ensure that no pollen was lost. None was lost. The $\mathrm{ZnBr}_{2}$ solution containing the pollen was placed into a $100 \mathrm{ml}$ beaker and $80 \mathrm{ml}$ of $95 \%$ ethanol (ETOH) was added to reduce the specific gravity and permit the pollen to sink during centrifuging (Jones and Bryant 2001). All of the solution in each sample was carefully spun down in $12 \mathrm{ml} \mathrm{CT}$ during eight separate centrifuging processes.

11. The final step consisted of rinsing the residue in each sample twice in ETOH, adding five drops of safranin-0 stain, then rinsing each CT once again in ETOH and centrifuging the CT. The remaining liquid was carefully poured off and the residue at the bottom of the CT was then poured into a one dram vial. Five drops of glycerin was added to each sample and the samples were placed on a warming plate to enable the remaining ETOH to evaporate overnight.

\section{Pollen Identification and Analysis}

When the remaining ETOH had evaporated in each of the processed pollen samples, I carefully stirred the residue in each vial. The objective is to thin the remaining residue enough so that when it is placed on a slide, all of the materials will remain in a single focal plane thereby not obscuring pollen grains that might be either above or below other objects. I then prepared a series of individual slides for each sample using the technique explained in the paper by Jones and Bryant (1998). Failure to prepare slides carefully and properly can result in skewed data results during the examination and counting of fossil pollen, as noted in experiments conducted by Brooks and Thomas (1967).

Pollen examination was performed using a NIKON OPTIPHOT binocular microscope at magnifications ranging from $400 \mathrm{x}-1000 \mathrm{x}$. Appropriate photographs of pollen were taken with an attached Nikon 950 COOLPIX camera. Identifications of pollen and spore types were checked against reference materials on file in the Texas A\&M Palynology Laboratory. These modern pollen reference materials include the Texas A\&M Modern Pollen Reference Collection, the Mobil Oil Modern Pollen Reference Collection, the Meredith Lieux Modern Pollen Reference Collection, and the AMOCO Modern Pollen Reference Collection.

Fossil Pollen: I scanned the prepared microscope slides from each of the 15 samples and found that overall the fossil pollen preservation was very poor and that there was a very low concentration of fossil pollen in the each of the samples. Some of the examples of degraded pollen are shown in Figure C-1.

The dominant types of pollen grains that could still be recognized in these 15 samples included mostly types produced by various composites, pollen from a few different grass species, and pollen in the group called Cheno-Am. There were also a few pine bladders. These pollen types are the most common types that tend to be found in highly degraded archaeological samples because they are among the most durable pollen types produced by nature (Bryant and Hall 1993).

During analyses of samples from Texas and the arid regions of the American Southwest, most palynologists divide fossil pollen in the Asteraceae (composite) plant family into a few specific categories. Overall, the composite family contains more than 1,500 genera and more than 22,000 species that grow in almost every known habit (Mabberley 1997). Asteraceae fossil pollen can be divided into certain categories. One primary group, which is insect-pollinated, is called the "high-spine (HS)" group because their pollen grains have a surface morphology consisting of long spines greater than 2.5 microns in length (Martin 1963). Three other major pollen groups within the composite family include: 1) the ragweed group, which consists of windpollinated types and are called "low-spine (LS)" types); 2) another group is insect-pollinated and has pollen grains that have a fenestrate morphology and belong in the tribe Lactuceae (dandelion types); and 3) the Artemisia or wormwood group. A few of the other pollen types produced by plant genera within the composites are very distinctive and can often be identified and listed separately by a specific genus. Several of these include Centaurea (star thistle), Cirsium (thistle), and Mutisia (mutisia). For most of the 1,500 genera of composites, the pollen morphology is not 


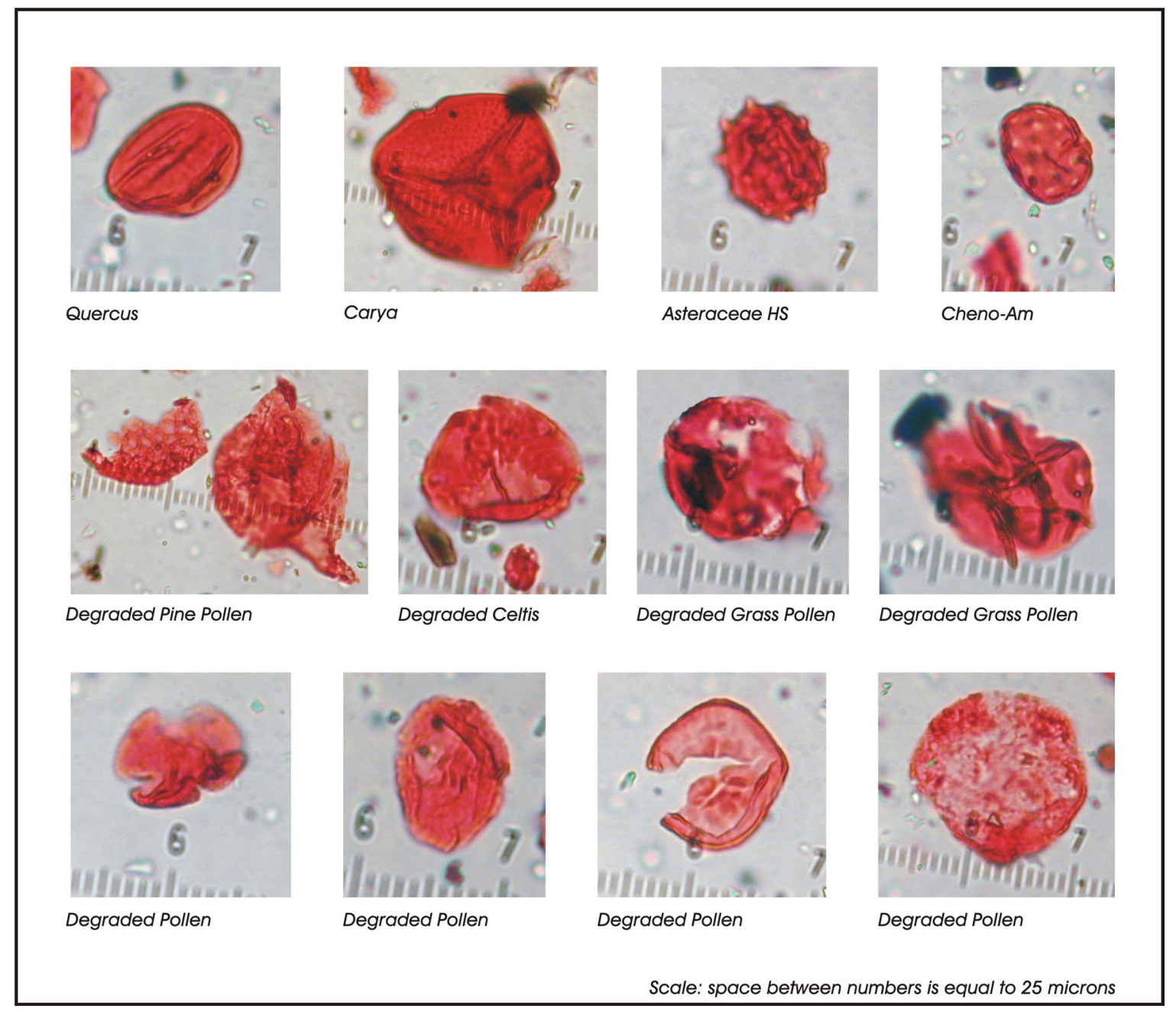

Figure C-1. Selected pollen types from site samples.

distinctive enough to warrant separation into specific genera without extensive keys produced at the scanning electron (SEM) or transmission electron microscope (TEM) levels.

\section{Discussion}

Pollen analyses form the database for many types of interpretations ranging from sequential changes in past environments to information about the lifestyles and diets of prehistoric human populations. In each of these studies, the eventual interpretation of pollen data must account for all factors that may have influenced the composition of the original pollen rain, and later for the factors that may have affected and altered the composition of the buried pollen assemblage.
During the last 50 years, palynologists have learned that there are many complex factors that determine the original composition of the pollen rain in a region. These include factors such as: 1) types of pollination; 2) differences in pollen production; 3 ) differential dispersion patterns; and 4) the size, weight, and aerodynamic ability of pollen types to remain airborne. In addition, for some locations, pollen deposition will also be influenced by the activities of animals, birds, or humans using the site area. Once deposited, other factors influence the eventual loss or recovery of specific pollen types. These factors include: 1) pollen recycling and/or mixture due to wind, water, human, or animal interference; 2) the chemical composition of a pollen grain's wall (exine); 3) the morphological shape and surface ornamentation type of each pollen type; and 4) the susceptibility of each pollen type to various types of 
degradation processes including those from mechanical, chemical, or biological agents (Bryant et al. 1994; Bryant and Hall 1993; Campbell and Campbell 1994; Holloway 1989; King et al. 1975; O’Rourke 1990).

As noted by Jackson and Lyford (1999) and others, there are substantial differences among plant taxa in terms of their pollen production, methods of dispersal, and in the ability of their pollen grains to remain aloft and travel various distances from their dispersal source. These differences create an uneven distributional relationship between the amount of pollen that will fall to the ground (pollen rain) and the actual vegetational coverage of each plant taxon. Adding to this problem is the knowledge that a large number of plants produce small amounts of pollen that rarely is cast adrift into the atmosphere because the plants rely on insect or animal pollinators. These pollen types are seldom found in the normal pollen rain of a region even though the plants that produce them compose a major portion of the vegetational coverage. Finally, animals and humans gathering plants for food or for other purposes can artificially introduce additional amounts and types of pollen into the pollen spectrum of a region.

Once deposited, pollen is subjected to a host of potential factors that will determine whether or not the grains will remain preserved over time and, because not all pollen types are created equal, some types will succumb to destruction much more rapidly than will other more durable types.

One of the first agents that can affect pollen grains is mechanical degradation. After pollen is released from its source, it can become abraded or broken during the transportation phase before it falls to the ground and becomes part of the pollen rain. These alterations can result from impact or from changes in climatic conditions. Studies by Duhoux (1982), for example, have shown that changes in the level of atmospheric moisture can result in high numbers of exine ruptures in closely related, thin-walled pollen taxa such as Juniperus and Thuja. Later, after being deposited, many of the thin-walled pollen types, as well as other pollen types, can become further abraded by various types of animal disturbances, and frequently by the cultural practices of humans that might include activities such as burning, land surface modifications, construction activities, and agricultural practices. Mechanical abrasion of pollen can also occur from various other causes in the natural environment including impact against objects, exposure to water, recycling and wind erosion, changes in temperature, changes in atmospheric or soil moisture levels, volcanic eruptions, and soil movement.

The morphological structure and ornamentation of pollen walls seem to be important factors in determining their potential susceptibility to mechanical degradation. For example, protruding structures on certain pollen grains, like the bladders of many conifer species or the spines of some composites and mallows, have a tendency to break or erode through a variety of mechanical processes. In some cases, the actual appearance of a pollen grain may become so altered after the loss of an appended structure, or structures, that accurate identification is no longer possible. In addition, structural alteration by mechanical processes can also cause severe exine weakening, thereby hastening the eventual destruction of the entire grain through other processes. An analogy would be the difference between a whole egg and one that has a hair-line crack. The whole egg is much stronger and durable than the one with even a tiny crack.

Soil chemistry, acting on the natural chemical composition of a pollen grain's exine, is another factor that often plays an important role in determining pollen preservation. Although the exine is composed mostly of cellulose and various types of proteins, there are interlocking strands of a highly durable material called sporopollenin. Studies by chemists and palynologists including Brooks and Shaw (1968), Shaw (1971), Rowley and Prijanto (1977), and Rowley et al. (1990) have discovered that differences in the amount of sporopollenin and differences in its specific molecular structure within the exine of a pollen grain will make specific pollen types either more, or less, resistant to various types of chemical deterioration.

One of the primary indications of potential pollen preservation in sediments can be gained by determining the soil $\mathrm{pH}$. By itself, $\mathrm{pH}$ is not entirely responsible for pollen destruction, but it is an important factor. As early as the 1950s, Dimbleby (1957) searched for causes of pollen deterioration in various types of soils. His experiments and research were the first to chart differences in pollen preservation caused by soil chemistry. His research revealed that most soils with an acidic $\mathrm{pH}$ seem to provide ideal deposits for pollen preservation. However, he noted that once soil $\mathrm{pH}$ levels reach the weakly acidic level of 6.0, significant pollen destruction can begin to occur. Dimbleby even cautioned that attempts to recover fossil pollen from soils with a pH greater that 6.0 would most probably result in failure. Since Dimbleby's original study, other studies 
by palynologists including Bryant et al. (1994), Hall (1981), and Martin (1963) have demonstrated that fossil pollen can be recovered from slightly acidic and even alkaline soils with a $\mathrm{pH}$ as high as 8.9. Nevertheless, as noted in the study by Bryant and Hall (1993), in most cases the recovered fossil pollen from such sediments is often in a poor state of preservation, is highly deteriorated, and frequently presents evidence of differential preservation (i.e., many of the fragile pollen types have disappeared leaving behind only the most durable pollen types).

Related to Dimbleby's (1957) initial study on soil $\mathrm{pH}$ is Tschudy's (1969) later research on the effects of Eh (oxidation potential) on the preservation potential of pollen in various types of sediments. Tschudy noted that Eh seems to be a better indicator than $\mathrm{pH}$ of the potential preservation or destruction of pollen. Sediments with a low Eh (from -1 to 0 ) reflect a reducing, anaerobic type of condition where carbon dioxide and hydrogen sulfide are often present and result from the by-products of microbe respiration. This combination decreases the levels of oxygen and also lowers $\mathrm{pH}$ values. Thus, the creation of a negative Eh value results in the formation of a strongly reducing environment (Tschudy 1969). Because a reducing environment retards oxygen retention, which will oxidize organic compounds, and presents a less favorable habitat for certain types of bacteria and fungi which feed on pollen, a low soil or sediment Eh becomes ideal for pollen preservation. One of the common types of sediments with a low Eh potential is the acidic peat bog, which is among the best locations to recover fossil pollen. Likewise, as the Eh potential of sediments rises from 0 to +1 , it indicates oxidizing conditions which speed the destruction of pollen in two ways: first, by direct oxidation, when pollen grains come in contact with free oxygen, and second, when pollen comes in contact with oxygenated water from the surface that percolates into subsurface levels. This second type of oxidation is often more prevalent, especially in well-drained soils containing an ample sand content. The oxygenation of subsurface soil levels also provides an ideal habitat for certain species of pollen-eating bacteria and fungi.

Not all pollen types are created equal. The chemical composition of the pollen walls of some plant species is not nearly as durable as it is in other types. In addition, the structural morphology of the pollen wall plays an important role in determining whether or not a specific type of pollen grain will remain preserved in various types of sediments. In a 20-year study beginning in 1964 and ending in 1984,
Havinga $(1964,1984)$ reported that the relationship between the structure and percentage of sporopollenin in the wall composition of pollen grains seems to affect their susceptibility to eventual destruction by oxidation. He found, for example, that pollen grains having high percentages of sporopollenin in their walls tended to remain preserved longer, even in soils with high $\mathrm{pH}$ and Eh values, than did pollen grains with walls composed mostly of cellulose and proteins.

Subsequent to Havinga's initial study, Rowley et al. (1990) conducted detailed SEM and TEM studies of the various pollen types used by Havinga during his 20-year study. The study by Rowley and his colleagues provides a detailed explanation and ample illustrations of the destructive processes that affect pollen in various types of soil conditions.

Biological agents, including certain species of fungi and bacteria, can cause damage to pollen grains that will speed their eventual destruction. Studies by Holloway (1989) noted that some types of Phycomycete fungi will seek out and feed on the nutrient materials in the cytoplasm of recently-deposited pollen grains. His experimental studies show that the filamentous threads of fungi, called hyphae, will often enter a pollen grain through one of the grain's natural aperture openings. Nevertheless, at other times the fungal hyphae seem to have the ability to dissolve areas of the pollen wall in order to enter the grain. Both types of fungi attack and weaken the wall structure of pollen, and speed the grain's eventual destruction by other forms of chemical and mechanical degradation.

Some years earlier, Goldstein (1960) conducted experiments with various species of Phycomycete fungi and found they were a causative factor in the destruction of pollen. His original study revealed that certain species of Phycomycetes seem to be selective in their preference for pollen types. One group of Phycomycetes, for example, seemed to prefer to infect certain types of conifer pollen, even when other pollen types were available. Unlike Holloway's later study in 1989, Goldstein did not focus on how fungi actually damaged pollen grains. Instead, Goldstein was primarily concerned with the percentage of pollen that would be infected and which pollen taxa seemed to be the most susceptible to fungi infection.

Elsik (1966) was the first to note that bacterial degradation of pollen grains occurs. He found that certain bacteria, especially certain species of Actinomycetes, will degrade 
pollen walls and seem to do so in a specific pattern. He found that although much of the bacterial infection of pollen seems to occur when the pollen contains cytoplasm, in some cases this type of bacterial destruction continues long after the pollen grains have lost their cytoplasm and have become part of the sedimentary record.

Finally, one of the most destructive forces on pollen in sediments seems to come from repeated cycles of wetting and drying (Campbell and Campbell 1994). The walls of many pollen grains are fairly elastic, which enable them to expand and contract, depending upon the changing levels of atmospheric humidity (without rupturing) between the time they are released from the anther and the time they either reach their intended destination, or fall to the surface as part of the pollen rain. For those pollen grains that fall to the surface, their natural tendency to expand and contract, depending upon the different levels of available moisture, eventually weakens the grain over time and causes it to rupture or crack. Once weakened, pollen grains are much more susceptible to other processes of mechanical destruction. As Campbell and Campbell (1994) and Holloway (1989) have demonstrated in experimental studies, even one sequence of wetting and drying after pollen is deposited in soils can result in significant overall loss in terms of the total pollen concentration values per gram of soil. As the wetting and drying sequences continue, more pollen destruction occurs until at some point all pollen becomes destroyed.

Primarily due to the unfavorable soil and climatic conditions, the pollen study from this project does not provide us with sufficient fossil pollen to form any types of meaningful conclusions about either the paleoenvironment or significant cultural traits. Instead, these samples provide an excellent example of the many problems that confront archaeologists attempting to conduct fossil pollen studies from certain types of sites in the arid regions of Texas.

For over half a century, palynologists have been searching for answers as to why pollen remains perfectly preserved in some types of sediments and why fossil pollen in other sediments are either completely destroyed or selectively destroyed. Earlier I alluded to some of the studies that have already been done in an attempt to answer these questions. Nevertheless, our knowledge of pollen wall morphology, internal structure, and its chemical composition is still being debated. Also, we do not yet fully understand all of the elements that determine pollen destruction or preservation in different types of environmental settings.
I believe that one of the more important factors determining pollen preservation or destruction in the soils from the project area in this study is the frequency of soil saturation and subsequent drying. Various forms of pollen destruction and deterioration seem to be linked to phenomena associated with the evaporative process of changing a liquid into a gas. Experiments conducted by Burstyn and Bartlett (1975) showed that significant pressure is exerted on the curved surface of an organic-walled, hollow sphere (i.e., pollen grains) at the instant when water is transformed, by evaporation, from a liquid to a gas. This pressure phenomenon would be especially critical for water-filled, tiny, spherical structures such as pollen grains. As such, these forces could cause major structural damage to the thin, outer walls of pollen grains. Each time the soil hydrationdehydration process occurs from normal conditions, such as moisture from rain, followed by drying from wind and heat, pollen in the soil would be subjected to two potentially destructive processes. First, the expansion-contraction process caused by being dry and then wet, and second by the pressure phenomenon described by Burstyn and Bartlett (1975) in their study. The more frequently this cycle occurs in a soil, the greater the potential for fossil pollen to become distorted, crumpled, or destroyed (Campbell and Campbell 1994). The final destruction of the fossil pollen in soils often begins first by the development of stress areas and hairline cracks in the outer wall, and second by the crumbling of the pollen wall into fragments through additional mechanical processes.

In later studies that tested the Burstyn and Bartlett phenomenon on specific types of pollen, first Holloway (1981, 1989) and later Campbell and Campbell (1994) conducted controlled cycles of hydration-dehydration on soils containing pollen grains. Both authors noted that after only one hydration-dehydration cycle there were already significant changes and noticeable amounts of exine deterioration in some of the pollen types testing. In the Holloway experiment, he showed that $76 \%$ of the fresh pollen tested and $86 \%$ of the fossilized pollen tested already contained some degree of exine alteration and deterioration at the end of only 25 cycles of wetting and drying. Holloway's experiments also provided a clue about how differential pollen preservation can occur as a result of the hydration-dehydration process. Of the 14 pollen taxa he tested, those showing the greatest degree of alteration and destruction at the end of the 25 hydration-dehydration cycles were pecan (Carya), juniper (Juniperus), aspen and cottonwood (Populus), Douglas Fir (Pseudotsuga), willow (Salix), cattail (Typha), and maize (Zea mays). For many of 
these seven pollen types, the 25 hydration-dehydration cycles were so destructive that a number of the individual pollen grains could no longer be identified with certainty because of deterioration in the form of breakage, corrosion of surface areas, severe folding, warping, and/or degradation of the surface ornamentation. Some of the other types included in the Holloway experiment, such as the pollen of the low-spine composite (Iva) and the pollen of amaranths (Amaranthus), showed only minor degradation and those pollen types were still easily recognizable.

Hall (1981) pointed out from his studies of archaeological sites that fossil pollen assemblages in sites containing certain types of soil conditions become progressively altered and suffer more intensely from deterioration as the soil depth and time of exposure increases. He found that the percentage of degraded and indeterminate pollen increases as the depth of the deposits increase in sites with unfavorable conditions. Furthermore, as Hall's study demonstrates, the presence of low diversity of pollen types combined with high percentages of indeterminate pollen grains indicate significant losses of pollen by various types of deterioration. In most cases these pollen losses will be differentially distributed among the various fossil pollen taxa that were originally deposited. As noted in a later study by Bryant and Hall (1993), with increased amounts of destruction of fossil pollen in soils, the original, highly diverse pollen record becomes reduced down to only a few remaining pollen types. These last, remaining pollen types are generally represented by genera that produce pollen grains that are highly resistant to various agents of destruction, or are pollen types that have unique morphological features that enable them to be recognized even though they become severely degraded. As Bryant and Hall (1993) note, for many U.S. regions of the arid and semi-arid Southwest and West including west Texas, these last remaining identifiable pollen types most frequently include: 1) pine pollen;2) grass pollen; 3 ) pollen produced by various species of composites (including Artemisia); 4) Ephedra; and 5) pollen grains in the group called Cheno-Ams. As already noted earlier, what minor amounts of fossil pollen that could be identified in these 15 soil samples come mostly from these main pollen types and include very few other pollen taxa.

Previous studies (Bryant et al. 1994; Bryant and Hall 1993; Hall 1981, 1985) have also found that in most soils demonstrating severe examples of fossil pollen destruction, the total number of pollen grains remaining in each soil unit of weight $(\mathrm{g})$ or volume $(\mathrm{ml})$ usually decreases as the soil depth increases. Thus, the total pollen concentration values per gram of soil are usually the highest at the surface and continue to decrease as depth increases until total fossil pollen destruction occurs.

\section{Summary}

In conclusion, the fossil pollen record recovered from the 15 samples from this project does not provide any significant information that could be used for either environmental or cultural interpretations. The majority of the pollen is either totally missing due to oxidation and microbial destruction while it remained in the soil, or as illustrated (Figure C-1), the few more resistant grains show marked signs of being highly degraded and in many cases beyond confident identification. Although I did not examine the phytolith record in detail from these samples, I did look at a few of the silicate remains in some of the samples and found them to exhibit signs of surface erosion, probably from a host of elements including carbonic acid and HF ions in the ground water. I doubt that any further studies or searches for fossil pollen and/or phytoliths will result in any solid results. In summary, I believe that any additional studies of these samples would be a futile exercise and would be a waste of time and money. 


\section{References Cited}

Brooks, D., and K. W. Thomas

1967 The Distribution of Pollen Grains on Microscope Slides. Part I: The Non-randomness of the Distribution. Pollen et. Spores 9 (3):621-629.

Brooks, J., and G. Shaw

1968 Chemical Structure of the Exine of Pollen Walls and a New Function for Carotenoids in Nature. Nature 219: $523-524$.

Bryant, V. M.

1988 Preservation of Biological Remains from Archaeological Sites. In Interdisciplinary Workshop on the PhysicalChemical-Biological Processes Affecting Archaeological Sites, edited by C. Mathewson, pp. 85-115. U.S. Army Corp of Engineers Waterways Experiment Station, Vicksburg.

Bryant, V. M., and S. Hall

1993 Archaeological Palynology in the USA: a critique. American Antiquity 58(2):277-286.

Bryant, V. M., and R. G. Holloway

1983 The role of Palynology in Archaeology. In Advances in Archaeological Method and Theory 6, edited by M. Schiffer, pp. 191-224. Academic Press, New York.

Bryant, V. M., R. Holloway, J. Jones, and D. Carlson

1994 Pollen Preservation in Alkaline Soils of the American Southwest. In Sedimentation of Organic Particles, edited by A. Traverse, pp. 47-58. Cambridge University Press, London.

Burstyn, H. P., and A. A. Bartlett

1975 Critical Point Drying: Application of the Physics of the PVT Surface to Electron Microscopy. American Journal of Physics 43:414-419.

Campbell, I. D., and C. Campbell

1994 Pollen Preservation: Experimental Wet-Dry Cycles in Saline and Desalinated Sediments. Palynology 18:5-10.

Coil, J., M. A. Korstanje, S. Archer, and C. A. Hastorf

2003 Laboratory Goals and Considerations for Multiple Microfossil Extraction in Archaeology. Journal of Archaeological Science 30:991-1008.

Dimbleby, G. W.

1957 Pollen Analysis of Terrestrial Soils. New Phytologist 56:12-28.

Duhoux. E.

1982 Mechanism of Exine Rupture in Hydrated Taxoid Type of Pollen. Grana 21:1-7.

Elsik, W. K.

1966 Biologic Degradation of Fossil Pollen Grains and Spores. Micropaleontology 12:515-518. 
Erdtman, G.

1960 The Acetolysis Method: A Revised Description. Svensk Botanisk Tidskrift 54:561-564.

Goldstein, S.

1960 Destruction of Pollen by Phycomycetes. Ecology 41:543-545.

Hall, S. A.

1981 Deteriorated Pollen Grains and the Interpretation of Quaternary Pollen Diagrams. Review of Paleobotany and Palynology 32:193-206.

1985 Quaternary Pollen Analysis and Vegetational History of the Southwest. In Pollen Records of Late-Quaternary North American Sediments, edited by V. M. Bryant, Jr. and R. G. Holloway, pp. 95-125. American Association of Stratigraphic Palynologists Foundation, Dallas.

Havinga, A. J.

1964 Investigations into the Differential Corrosion Susceptibility of Pollen and Spores. Pollen et Spores 6:621-635.

1984 A 20-year Experimental Investigation into the Differential Corrosion Susceptibility of Pollen and Spores in Various Soil Types. Pollen et Spores 26:541-558.

Holloway, R. G.

1981 Preservation and Experimental Diagenesis of the Pollen Exine. Ph.D. Dissertation, Texas A\&M University (Botany), College Station, Texas.

1989 Experimental Mechanical Pollen Degradation and its Application to Quaternary Age Deposits. Texas Journal of Science 41:131-145.

Hunt, C. O,

1985 Recent Advances in Pollen Preparation Techniques: A Brief Review. British Archaeological Review International Series (Archaeological Series) 266:181-187

Jackson, S. T., and M. E. Lyford

1999 Pollen dispersal models in Quaternary plant ecology: assumptions, parameters, and prescriptions. The Botanical Review 65(1):39-75.

Jones, G., and V. Bryant

1998 Are all counts created equal? In American Association of Stratigraphic Palynologists Foundation Contribution Series No. 33: New Developments in Palynomorph Sampling, Extraction, and Analysis, edited by V. M. Bryant and J. H. Wrenn, pp. 115-120. American Association of Stratigraphic Palynologists Foundation Contribution, Dallas, Texas.

2001 Alcohol Dilution of Honey. In Proceedings of the IX International Palynological Congress, Houston, Texas, U.S.A., 1996, edited by D. K. Goodman and R. T. Clarke, pp. 483-488. American Association of Stratigraphic Palynologists Foundation, Dallas, Texas.

King, J., W. E. Klippel, and R. Duffield

1975 Pollen Preservation and Archaeology in Eastern North America. American Antiquity 40(2):180-190.

Lentfer, C. J., M. M. Cotter, and W. E. Boyd

2003 Particle Settling Times for Gravity Sedimentation and Centrifugation: A Practical Guide for Palynologists. Journal of Archaeological Science 30:149-168. 
Mabberley, D. J.

1997 The Plant Book. Cambridge Press, Cambridge, United Kingdom.

Maher, L. J., Jr.

1981 Statistics for Microfossil Concentration Measurements Employing Samples Spiked with Marker Grains. Review of Palaeobotany and Palynology 32:153-191.

Martin, P. S.

1963 The Last 10,000 Years: A Fossil Pollen Record of the American Southwest. University of Arizona Press, Tucson.

O’Rourke, M. K.

1990 Pollen Reentrainment: Contributions to the Pollen Rain in an Arid Environment. Grana 29:147-152.

Riding, J. B., and J. E. Kyffin-Hughes

2004 A Review of the Laboratory Preparation of Palynomorphs with a Description of an Effective Non-acid Technique. Revista Brasileria de Paleontologia 7(1):13-44.

Rowley, J. R., and B. Prijanto

1977 Selective Destruction of the Exine of Pollen Grains. Geophytology 7:1-23.

Rowley, J. R., J. S. Rowley, and J. Skvarla

1990 Corroded Exines from Havinga's Leaf Mold Experiment. Palynology 14:53-80.

Shaw, G.

1971 The Chemistry of Sporopollenin. In Sporopollenin, edited by J. Brooks, P. Grant, M. Muir, P. van Gijzel, and G. Shaw, pp. 305-350. Academic Press, New York.

Tschudy, R. H.

1969 Relationship of Palynomorphs to Sedimentation. In Aspects of Palynology, edited by R. Tschudy and R. Scott, pp. 79-96. Wiley \& Sons, New York. 